\title{
" برنامج قائم على أدب الأطفال لتنمية بعض المفاهيم البيولوجية لطفل الروضة "
}

\section{| (عداد}

د/ ياسمين أحمد حسن محمد (*)

\section{مقدمة}

يثهد العصر الحالي تطورًا سريعًا في كافة مجالات الحياة مما أدى إلى زيادة المعرفة العلمية في مختلف فروع العلم والمعرفة، ومما لا شك فيه أن الاهتمام بالطفل هو اهتمام بالحاضر والمستقبل حيث يُعد الاهتمام بالطفل مؤشرًا حضاريًا لتقدم الأمم فأطفال اليوم هم شباب الغد وثروة المستقبل. وتمثل المفاهيم العلمية النسيج الذي يربط حقائق العلم ومكوناته ويعطيها معني أعمق وأدق، فالمفاهيم العلمية هي اللبنات الأساسية التي يقوم عليها العلم (عبد الله بن خميس وسليمان بن محمد، 9 . . ب : 01). وللمفاهيم العلمية أهمية كبيرة للطفل حيث تساعده في التعرف على الظواهر وتمبيزها وتفسير المواقف التي تحيط به وتقلل من تعقدها، وتتضمن المفاهيم العلمية أبعاد وأفكار عديدة ومنتوعة يمكن تقديمها للطفل من خلال أنشطة تعليمية متعددة تساعده في فههها بفهم أعمق، وعلى المعلمة تقديم المفاهيم العلمية للطفل من خلال خبرات وأنشطة متتوعة تساعده على تطبيق التعلم الذي حصل عليه في مجالات مشابه .(Lake,2000: 26)

وقد أكدت دراسة (2008) ودراسة Mantzicopoulos et al. وق مo Diamond (2012) ودراسة (2018) عusaro \& Smith على أهمية وتوفير وتقديم المفاهيم العلمية لطفل الروضة حيث أنها تساعد في تتمية مهارات التفكير العلمي كالفهم والملاحظة وحل المشكلات والاستكثاف وتحليل المعلومات وتشكيل الاستتناجات. ويشير الحية من حيث دورة حياتها وتكيفها مع بيئتها ويجب استثمار ذلك وتتجيع الطفل على المراقبة والاستكثاف. وقد أكدت دراسة Decoster et al (2014) على أهمية تقديم المفاهيم البيولوجية لطفل الروضة حيث أنها تساعد في الإجابة على العديد من تساؤلات الطفل وتساعده على التفكير بشكل علمي من خلال

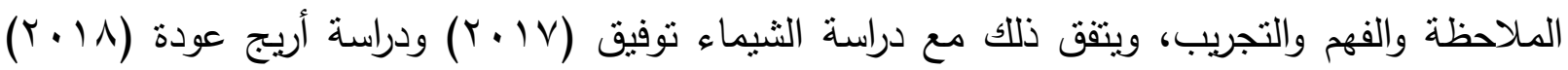

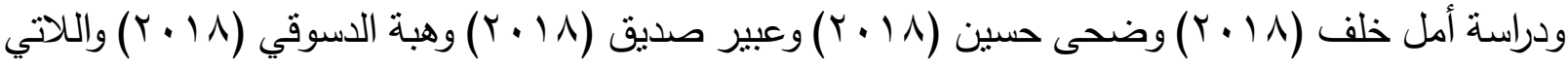
أكدوا جميعًا على أهمية تتمية المفاهيم البيولوجية لطفل الروضة. ويمنل أدب الأطفال العصا السحرية الذي بستطيع المعلمات والأباء أن بدخلو بها إلى عقول الأطفال وقلوبهم في وقت واحد، فيشكلون العقل والوجدان لدى الطفل، يدخلون إلى العقل فيسهون في بناء إطار 
معرفي وثقافي وفكري، ويدخلون إلى القلب ويسهمون في بناء إطار قيمي وخُلقي، ليتكامل الإطاران الثقافي

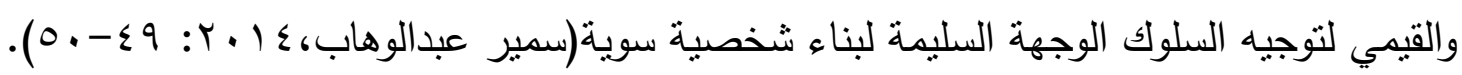

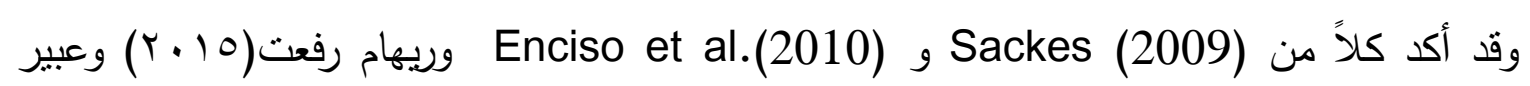
بكري(9 1 • r) على فاعلية أدب الأطفال في تتمية الدفاهيم العلمية والمهارات الحياتية لطفل الروضة بالإضافة أن أدب الأطفال يشعر الطفل بالمتعة ويزيد من دافعيته للتعلم لذلك فإن البحث الحالي بسعى لنوظيف أدب لإبه

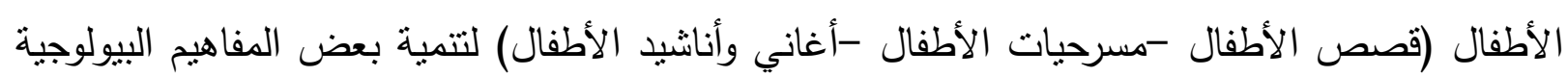

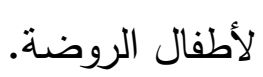
مشكثة البحث لقد بدأ الإحساس بمشكلة البحث من خلال إثراف الباحثة على طالبات التثريب الميداني، حيث لاحظت وجود قصور واضح في أنشطة الروضة التي تعتدد على تبسيط المفاهيم متل أدب الاطفال، وقد

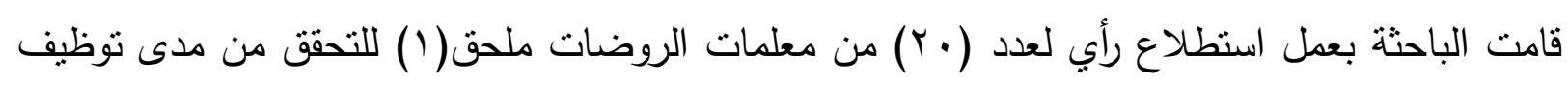

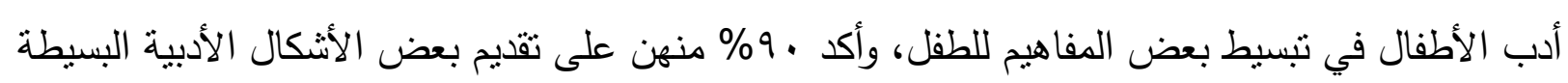
كالقصة ويقتصر على الجانب التزفيهي فقط للأطفال، كما لاحظت الباحثة وجود قصور في تنتاول المنهج الحديث للمفاهيم البيولوجية منل (السلسلة الغذائية، خصائص الكائن الحي، وظائف الحواس لدى الإنسان،

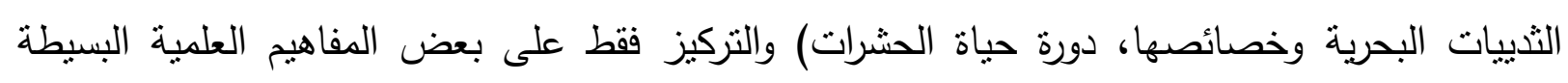

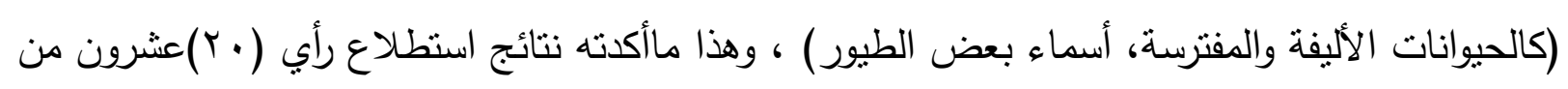

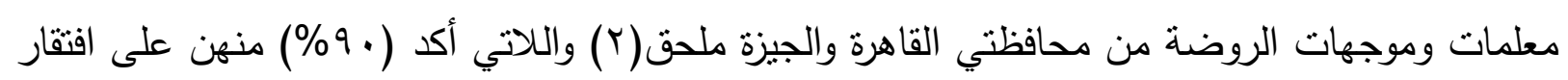
الروضة لأنشطة الدفاهيم البيولوجية الني تحث الطفل على التفسير والملاحظة والتعرف على الظواهر البيولوجية وأسبابها وأكد . ^\% منهن على نركيز الروضة على الأنشطة الأكاديمية كالقراءة والكتابة، وتقديم

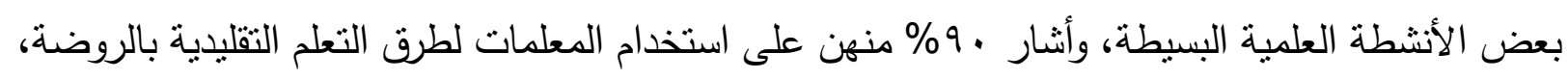
وهذا ما دفع الباحثة لتقديم البحث الحالي للتحقق من فاعلية أدب الاطفال في تتمية المفاهيم البيولوجية لطفل 


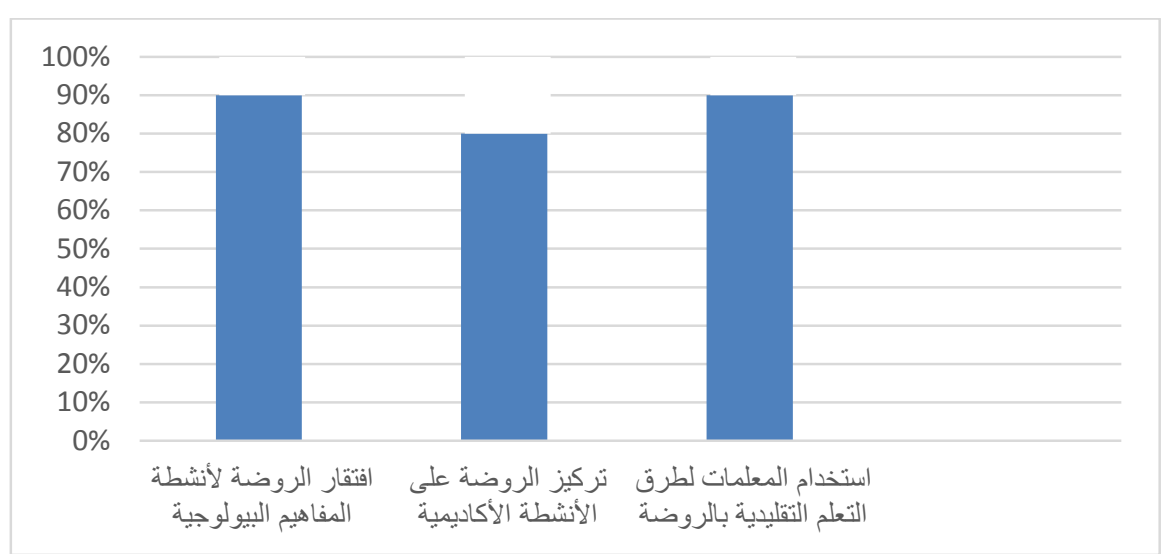

شكل (1)

يوضح نسب وجهات نظر معلمات الروضة حول مدى تقديم أنثطة المفاهيم البيولوجية بالروضة

وبناء عليه فقد تحدد مشكلة البحث في السؤال الرئيسي التالي :

ما فاعلية برنامج قائم على أدب الأطفال في تنمية بعض المفاهيم البيولوجية لأطفال الروضة؟ ويتقرع من السؤال الرئيسي عدد من الأسئلة الفرعية:

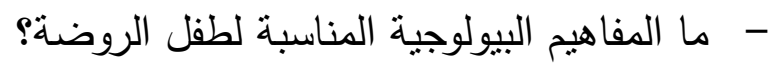

- ما الأشكال الأدبية التي يمكن أن تساهم في تتمية المفاهيم البيولوجية لطفل الروضة؟ - ما مكونات البرنامج القائم على أدب الأطفال المناسب لتتمية المفاهيم البيولوجية لأطفال الروضة؟

$$
\text { أهداف البحث: }
$$

1- تحديد أبعاد المفاهيم البيولوجية التي يجب تتميتها لأطفال الروضة. r- تحديد أثكال أدب الأطفال المناسبة لتتمية المفاهيم البيولوجية لأطفال الروضة ب- التحقق من فاعلية أدب الأطفال في تتمية المفاهيم البيولوجية لأطفال الروضة.

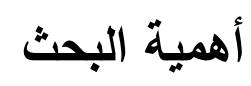

الأهمية النظرية

- - التأكيد على أهمية استخدام أدب الأطفال في تتمية المفاهيم البيولوجية لأطفال الروضة. - - إلقاء الضوء على أبعاد المفاهيم البيولوجية التي ينبغي تتميتها لأطفال الروضة، متمثلة في (الإنسان-

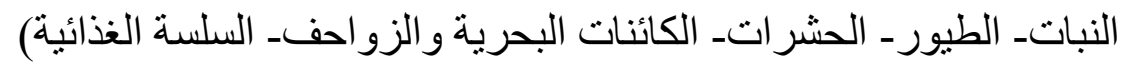

الأهمبة التطبيقية

- - تشجيع معلمات رياض الأطفال على استخدام أدب الأطفال وتوظيفها في أنشطة الروضة. - - تقديم برنامج لتتمية المفاهيم البيولوجية مع أطفال الروضة باستخدام أنشطة أدب الأطفال تسترشد به المعلمات في هذا المجال. 
مصطلحات البحث (وقد عرفتها الباحثة إجرائيًا)

$$
\text { أدب الأطفال }
$$

"الفنون الموجهه للأطفال لتتمية بعض المفاهيم البيولوجية لديهم وهذه الفنون تشمل القصة والمسرحية والأغاني

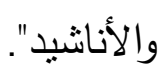

r - المفاهيم البيولوجية: استنتاجات عقلية يصل إليها الطفل ويكونها من خلال دراسة الحقائق المهائ المرتبطة بالكائنات الحية من

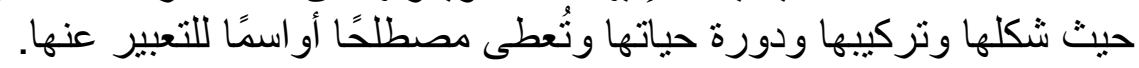

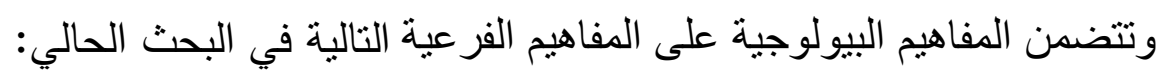

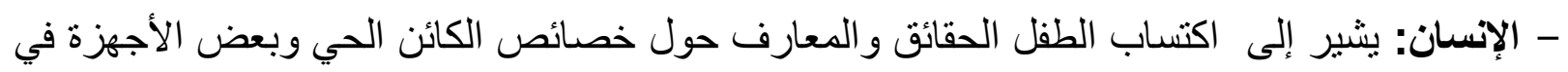
جسم الإنسان وحو اسة. - - النبات: يشير إلى اكتساب الطفل الحقائق والمعارف حول ظاهرة الإنبات ومكونات ووظائف أجزاء

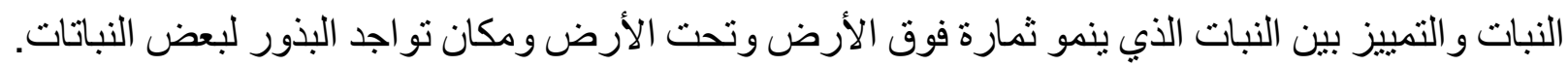

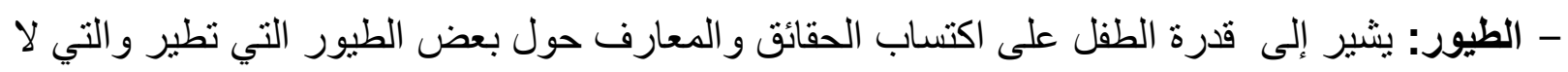
تطير، الطيور الجارحة، الطيور المائية وغذائها. - الحشرات: يشثير إلى قدرة الطفل على اكتساب الحقائق و المعارف حول بعض الحشر التهات من حيث أجزاء

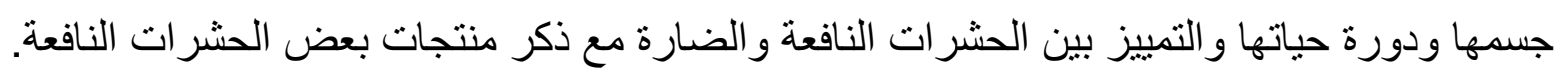

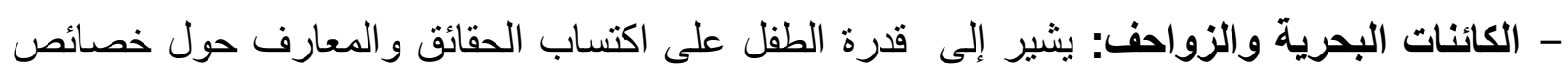
بعض الكائنات البحرية و الزواحف. - السلسلة الغذائية: يشير إلى اكتساب الطفل الحقائق و المعارف حول تحديد الكائن المنتج والمستهلك في السلسة الغذائية و القدرة على تكوين سلسلة غذائية.

\section{منهج البحث}

استخدمت الباحثة المنهج شبه التجريبي لمناسبته لطبيعة هذا البحث ذو المجموعتين التجريبية والضابطة

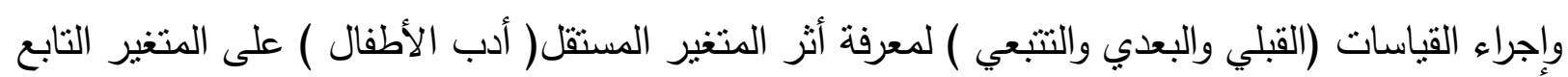
(الدفاهيم البيولوجية) لأطفال الروضة.

أدوات البحث

قامت الباحثة باستخدام الأدوات التالية

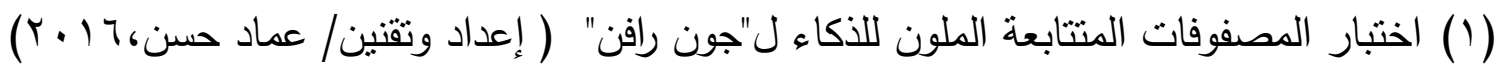

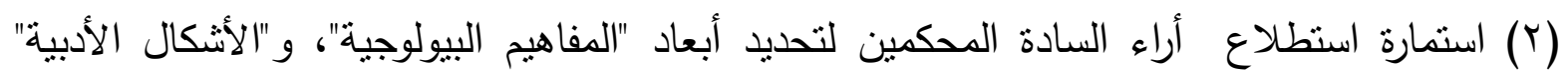

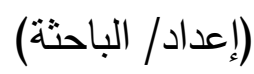
المناسبة لطفل الروضة. (إعداد/ الباحثة) (إعداد/ الباحثة) (r)مقياس المفاهيم البيولوجية المصور لأطفال الروضة. (؛ (؟طاقة ملاحظة سلوكيات أطفال الروضة حول المفاهيم البيولوجية. (إعداد/ الباحثة) 


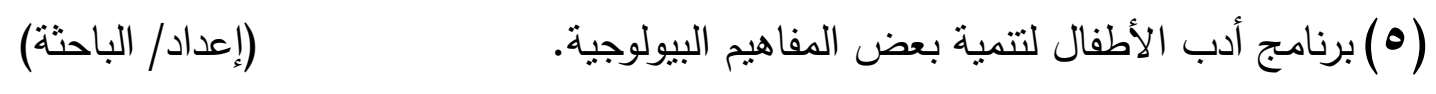

\section{فروض البحث}

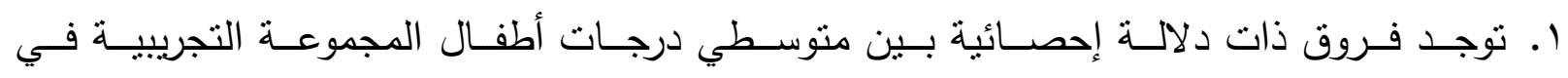

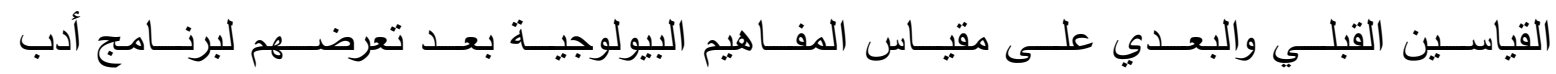
الأطفال لصالح القياس البعدي.

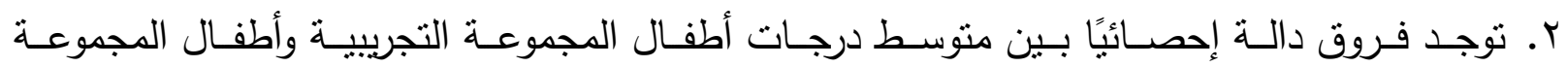

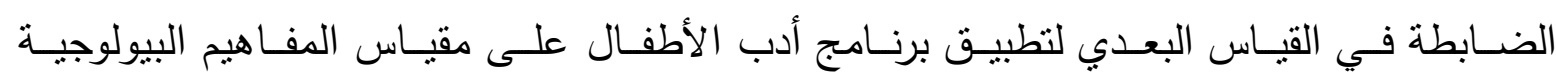
لصالح المجموعة التجريبية.

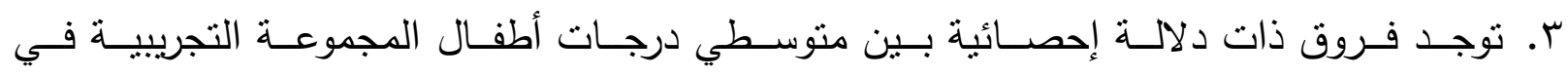

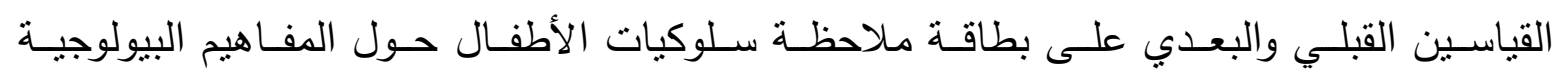

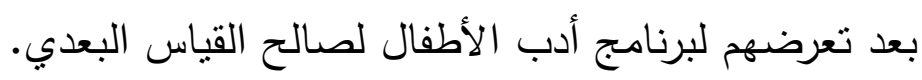

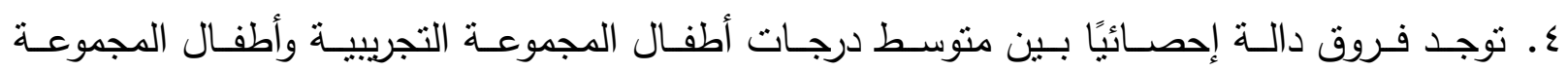

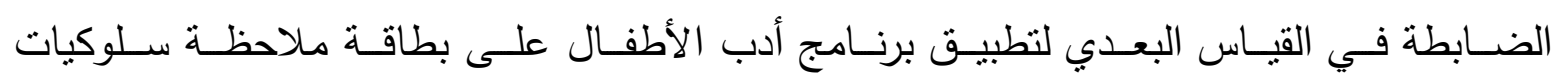

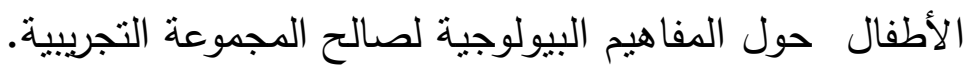

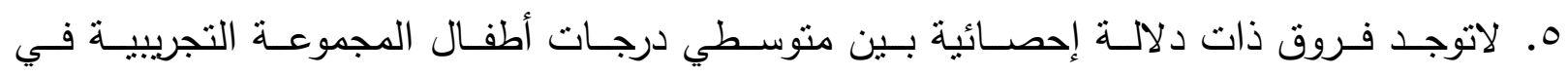

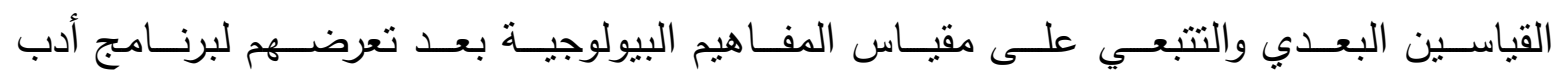

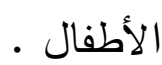

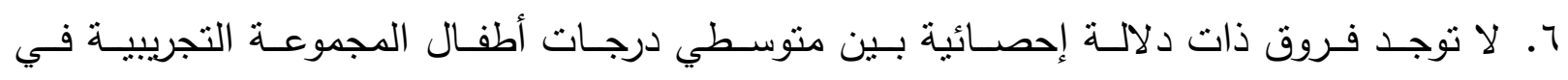

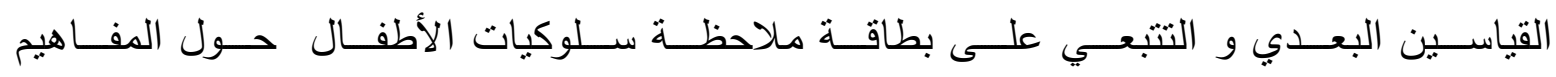

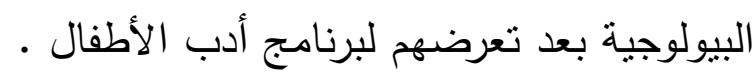

إطار نظري ودراسات سابقة

ينقسم الإطار النظري والدراسات السابقة إلى مبحثين رئيسيين وهما

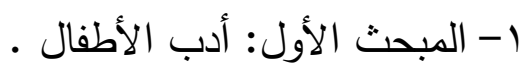
r- المبحث الثاني: المفاهيم البيولوجية.

\section{المبحث الأول : أدب الأطفال}

يعتبر الاهتمام بأدب الأطفال مؤشرًا هامًا لتقام الدول وذللك نظرًا للاور الهام الذي يقوم به أدب الطفل في

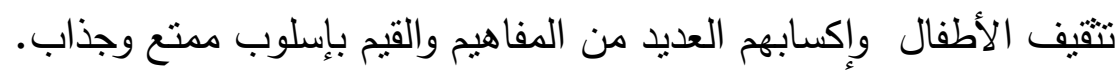

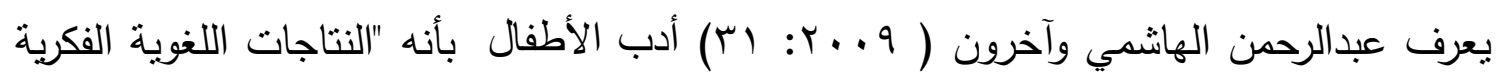
الأدبية التي تقدم للأطفال وتحدث في نفوسهم المتعة وتعمل على تشكيل شخصياتهم القادرة. وتكون ملائمة

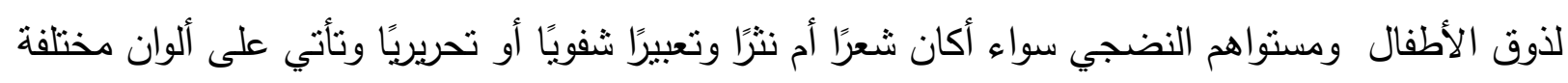

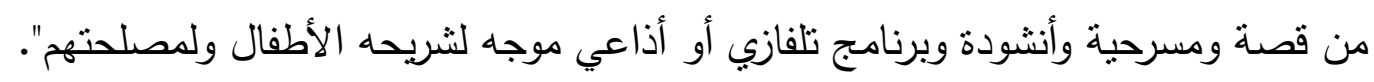


وتعرفه هدى قناوي (9 . . ب : 1 ())" بأنه "كل خبرة لغوية - لها شكل فني - ممتعة وسارة يمر بها الطفل ويتفاعل معها فتساعد على إرهاف حسه الفني والسمو بذوقه الأدبي ونموه المتكامل فتسهم بذللك في بناء شخصيته وتحديد هويته وتعليمه فن الحياة".

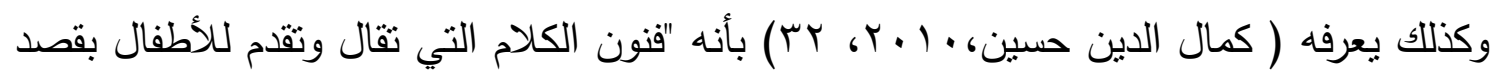

توجيه8ح".

وتعرف الباحثة أدب الطفل إجرائيًا بأنه: "الفنون الموجهه للأطفال لتتمية بعض المفاهيم البيولوجية لديهم وهذه الفنون تشمل القصة والمسرحية والأغاني والأناشيد". أهمية أدب الطفل يعتبر أدب الأطفال أفضل معلم لإكساب الطفل السلوكيات السليمة بطريقة ممتعة وشيقة بعيذًا عن التلقين والملل، هذا بالإضافة إلى قدرته في تحقيق الأهداف التعليمية التربوية بكل جوانبها المعرفية والوجدانية

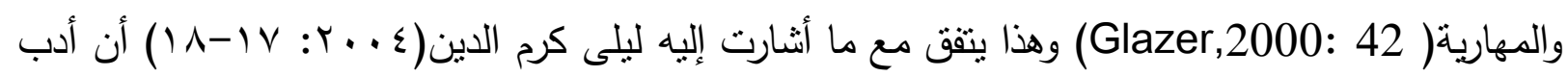
الأطفال يعتبر من أنجح وأكفأ الطرق والأساليب ليس فقط لإمتاع الأطفال وتسليتهم والتزفيه عنهم وإنما يكون له بالغ الأثر في تثقيفهم وتعليمهم، فأدب الأطفال قادر على تعليم الأطفال العلوم بمختلف فروعها ومنها العلوم البيولوجية، و إن أحسن اختيار إدب الأطفال يكون له أبلغ الأثر في تعلم الأطفال تعلمًا باقيًا وناجحًا وممنعًا للطفل.

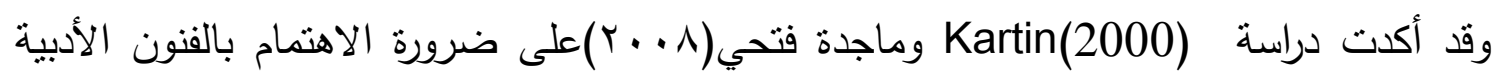
المختلفة واستخدمها كمدخل تربوي لتعليم الطفل وذلك لتأثيرها الإيجابي على الطفل، وفي هذا السياق فقد أكدت دراسة(Enciso, et al.2010 أن أدب الأطفال يشعر الطفل بالمتعة ويساعد على التعلم.

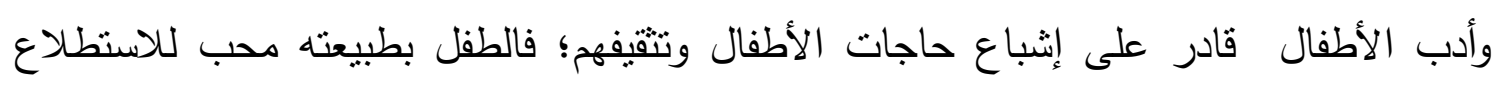

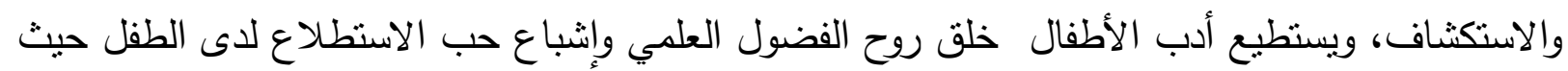

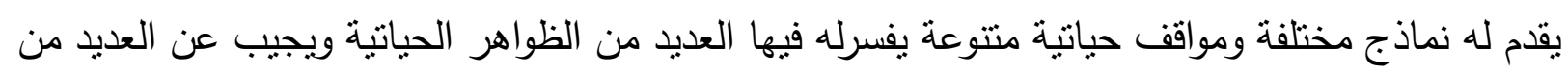

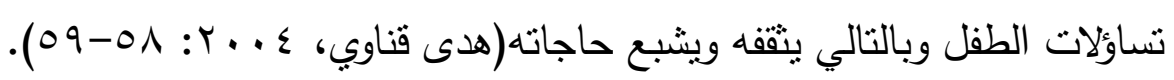

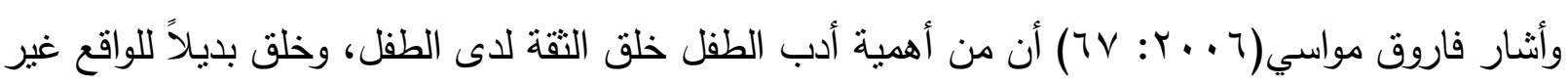

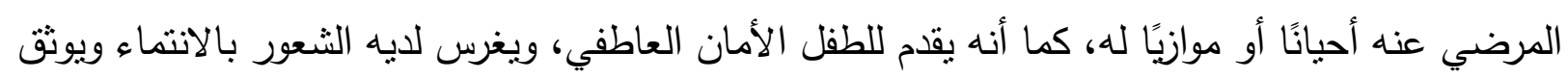

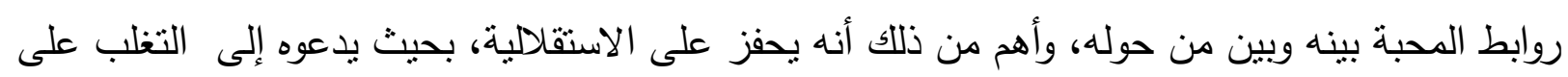

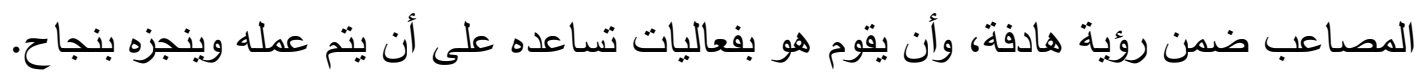

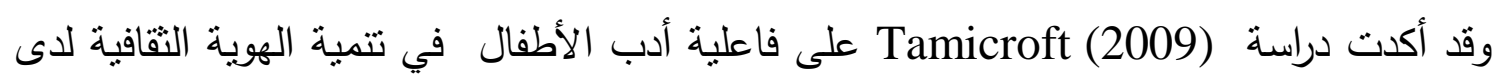

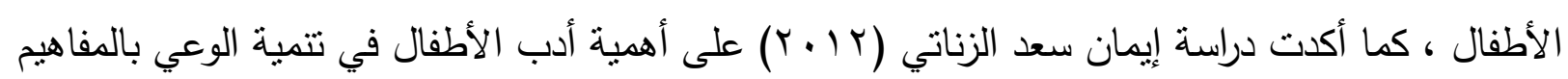


والسلوكيات والقيم المرتبطة بالتاريخ القومي لدى طفل الروضة، وكذلك فقد أثنارت دراسة حنان صفوت

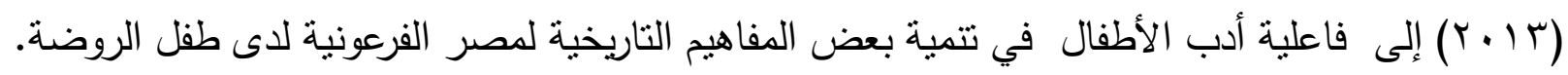

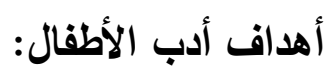
لقد تعددت الأهداف التعليمية والتزبوية لأدب الأطفال و ومنها:

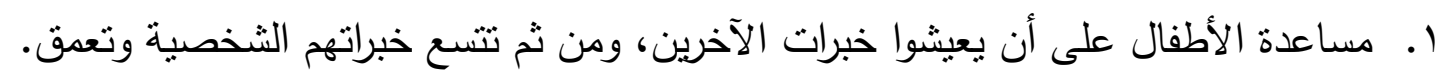

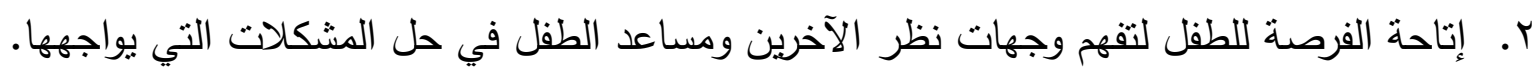
r. مساعدة الأطفال في فهم الثقافات الأخرى وأساليب الحياة فيها حتى يتمكنوا من التعايش معها.

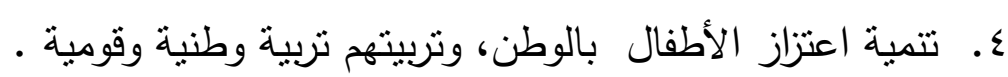
ه. تحقيق المتعة، وإثارة البهجة في نفس الطفل.

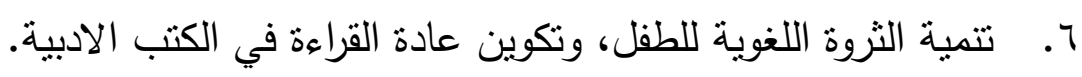
V. مساعدة الطفل على فهم الأساليب المجازية المختلفة وجوانب الجمال في اللغة. ^. مساعدة الطفل على إجادة الإلقاء وإخراج الكلمات والحروف إخراجًا سليمًا.

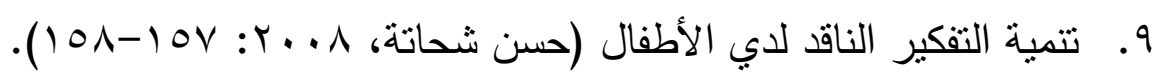
• ا ـ تزويد الطفل بالخبرات الحياتية والنماذج العلمية. 1) ا.تتمية الخيال وتتجيع الإبداع وإثارة العواطف والإنفعال بالأثشياء. r ا. ـ تتمية التذوق والثعور بالجمال وترقية الوجدان. با ـترقية السلوك وبث الأخلاق الحسنة.

ـ ا. تمكين الأطفال من إتمام عمليتي التعليم والتعلم، وذللك لتوفر العديد من الخبرات ومصادر المعرفة

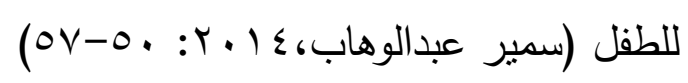

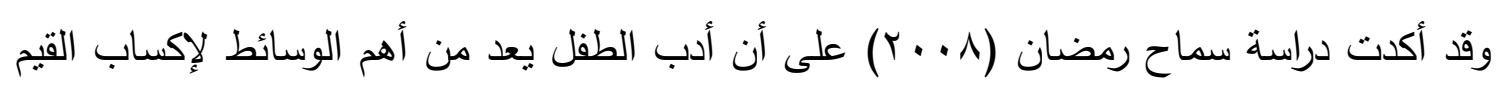

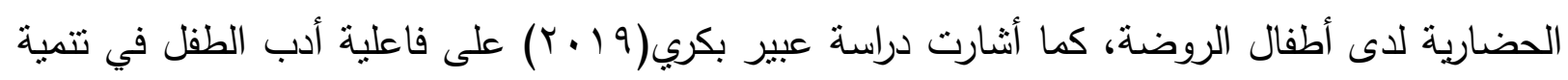
المهارات الحياتية لطفل الروضة.

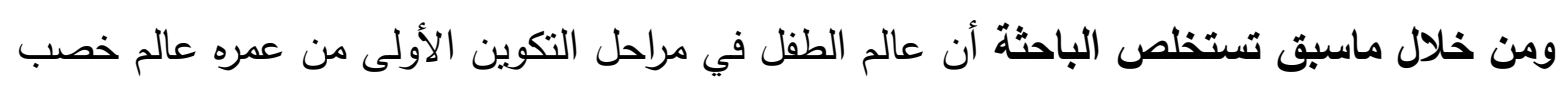

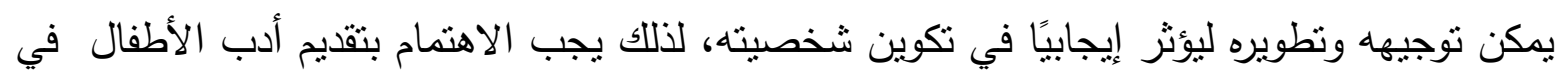

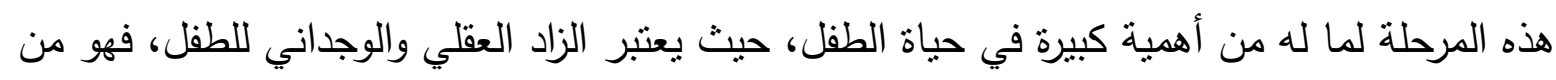

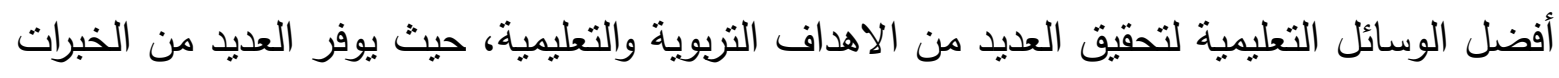

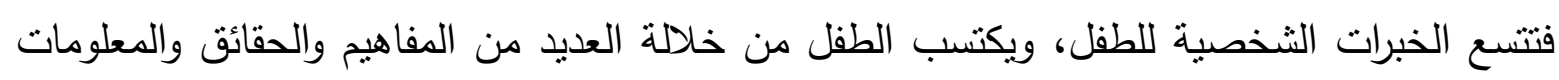
البيولوجية بإسلوب ممتع وجذاب مما يساعدة في الإجابه على العديد من تساؤلاته وتقسير العديد من الظواهر البيولوجية التي يلاحظها في بيئته. 
خصائص أدب الطقل

يشغل الأدب مساحة واسعة في الحياة لذا يجب عندما نقدم أدبًا للأطفال أن يراعي مستوياتهم العقلية

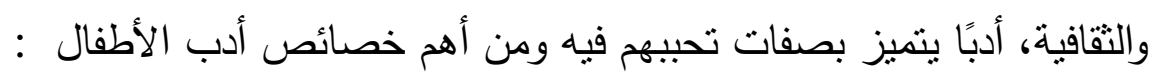

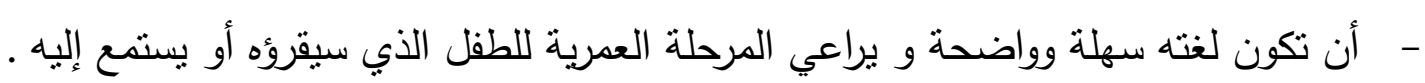

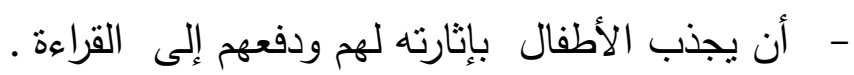

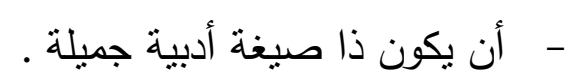

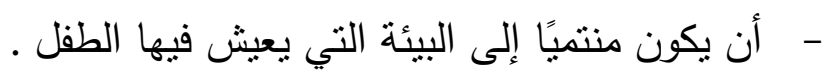
- - أن ينمي الخيال الواسع لدى الطفل فيتصور الأثياء ويربطها بغيرها، وينمي التفكير والإبداع لاى الطفل بحيث يستفيد مما يقرأ . - أن يبث في الطفل روح التسامح والتعاون والأخلاق القوية ومساعدة الناس . - - أن يحث الطفل على البناء، فيحافظ على ممتلكاته وممتلكات الغير وعلى بيئته .

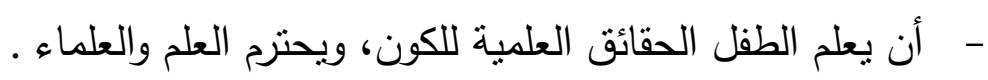

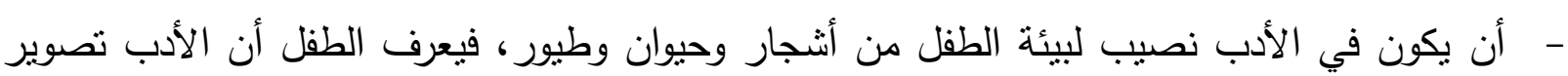

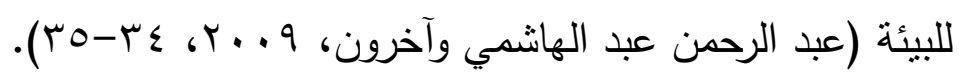

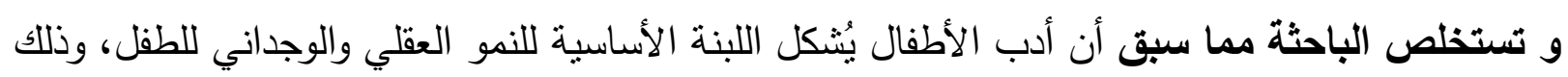

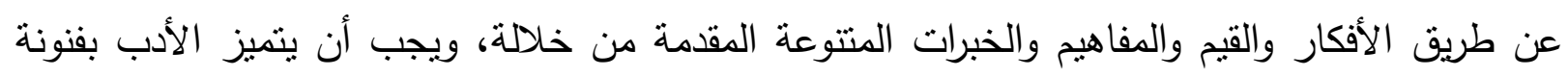

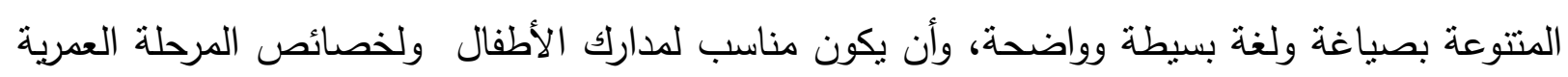
المقدم لها. بعض أنثكال أدب الأطفال أولاً : قصص الأطفال

تشكل القصة العمود الفقري لموضوعات أدب الأطفال وأثنكاله حيث إنها أقرب إلى الطفل، ومحبية

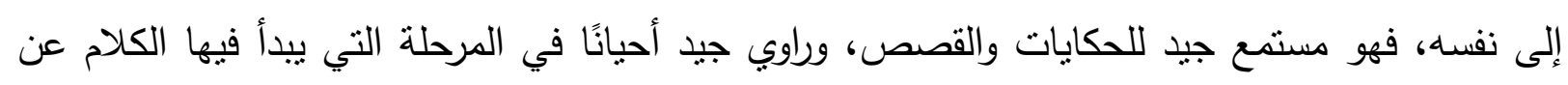

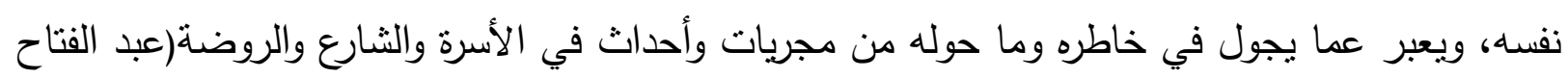

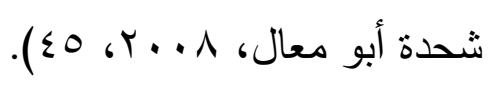

ولابد من الاهتمام بعناصر البناء الفني للقصة بحيث تكون ذات فكرة جيدة تثير انتباه الطفل ومناسبة

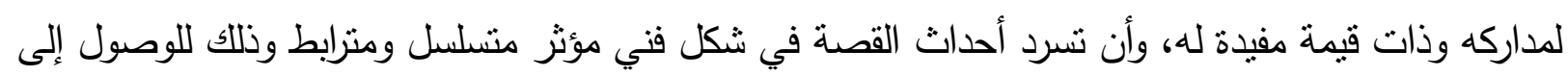

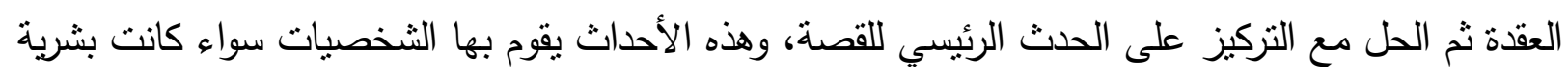

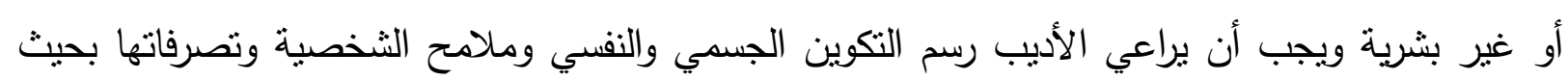

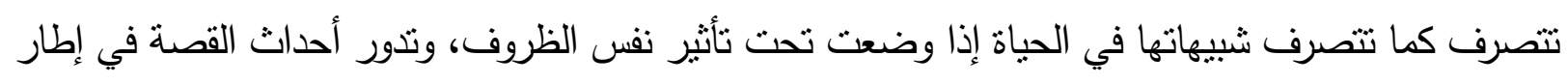

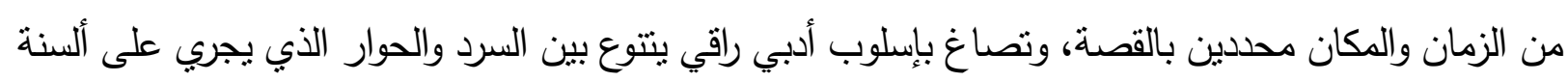


الثخصيات والذي يصور الانفعالات والعواطف ويمنح الأحداث حيويتها، ولذلك يجب اختيار اللغة واستخدام مفرداتها بجيث تكون واضحة ومُختارة اختيار جيد لتتاسب المرحلة العمرية المقدم لها العمل القصصي(محمد السيد

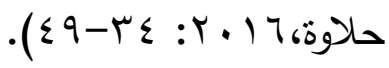
وتحظى القصة بمكانة مثميزة في أدب الأطفال وتعد من الفنون المؤثرة في سلوك الطلف، بالإضافة أنها

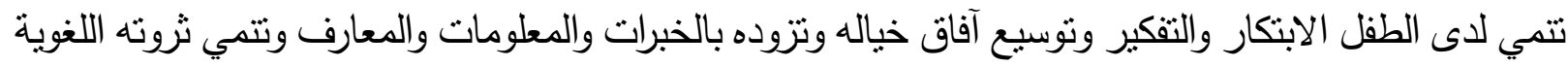

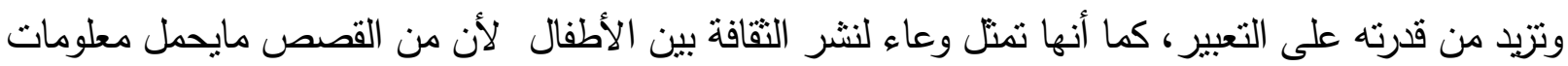

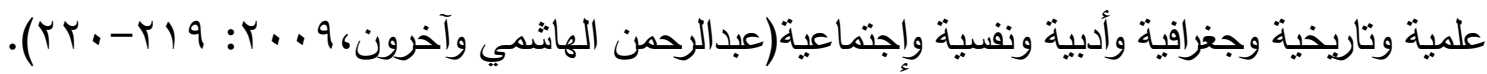

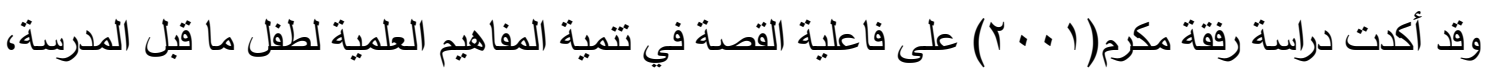

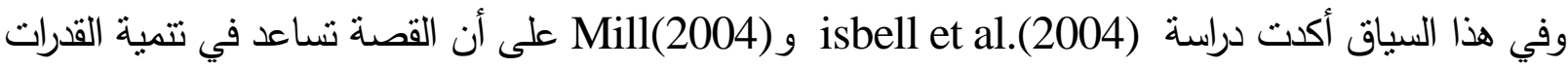
التعبيرية والمهارات اللغوية للطفل.

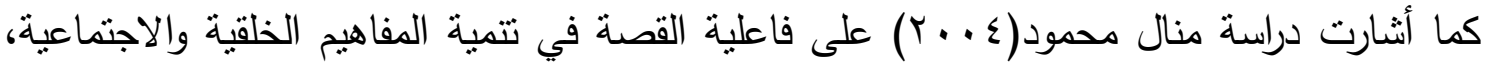

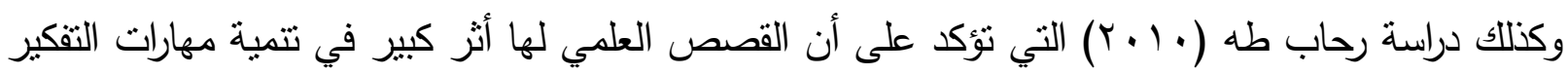

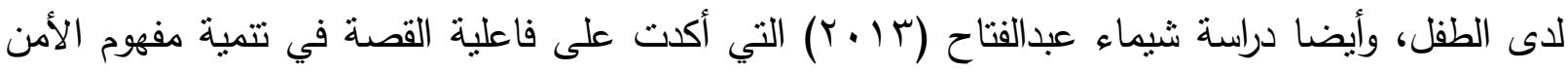

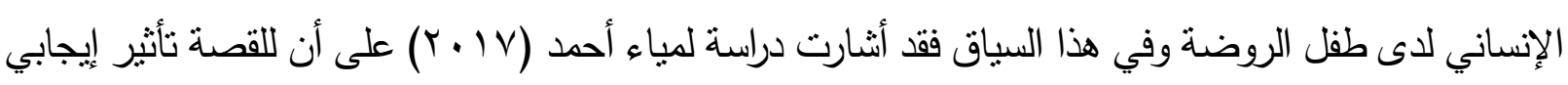
في إكساب الوعي السياسي للطفل. وتتعدد أنواع القصص التي تقدم للأطفال ومن هذه الأنواع القصص الاجتماعية المستمدة موضوعاتها من الحياه الواقعية من حيث العلاقة بين الأسرة والابناء والجيران والأعياد بحيث تدور حول الخبرات والتجارب اليومية والمشكلات التي تقابل الأطفال في تلاك المرحلة والتعرف على حلولها، القصص الدينية وهي كل مايستمد من القرأن والسنة وسيرة النبي والصحابة، القصص التاريخية وهدفها نُعرف الطفل على بلاده وأمجادها وأبطال أمته، القصص الفكاهيه وتسمى أيضا قصص النوادر والطرائف وتروي أحداثًا تنثير الضحك متلك بهن نوادر جحا، قصص البطولة والمغامرة وأبطالها عادة يساعدون الثرطة ويسعو للكثف عن الجناة عن طريق سلسلة من الأحداث، وقصص الخيال العلمي وهي تجمع بين العلم والخيال وتتتاول الاختراعات العلمية في الدستقبل، والقصص العلمية وهي تتضمن الكثبر من الحقائق والمعلومات عن الحيوان والنبات والماء والبحار والكائنات بصورة مبسطة وتعتبر وسيلة هامة يكتسب الطفل الكثير من الدفاهيم العلمية وأساليب التفكير الصحيحة من خلالها وتعمل على تتمية الاتجاهات الإيجابية لاى الطفل نحو العلم وتزويدة بالثقافة العلمية وحقائق العلم باسلوب ممتع وشيق وبالتالي يكتسب العديد من المفاهيم العلمية بثكل مبسط من خلالها (أمل

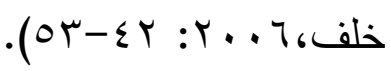


وتستخلص الباحثة مما سبق أن قصص الأطفال تعتبر احدى فنون الأدب المحببة للطفل ومن

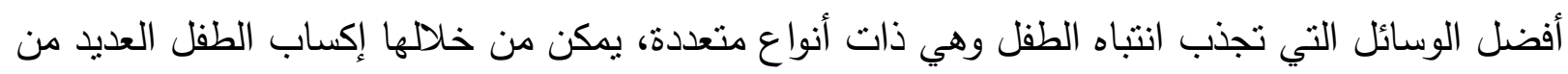
المعلومات العلمية والدفاهيم البيولوجية، وقد رأت الباحثة أن أفضل القصص التي تتاسب الدراسة الحالية والتي اعتمدت عليها هي القصص العلمية والاجتماعية وذلك لتقديم العديد من المفاهيم البيولوجية للطفل من خلالها بإسلوب شيق وجذاب ومبسط. ثانيًا :مسرحيات الأطفال

يعتبر مسرح الطفل من أحب ألوان الأدب إلى الأطفال ، لأنه يجمع بين أكثر من شكل من أثنكال

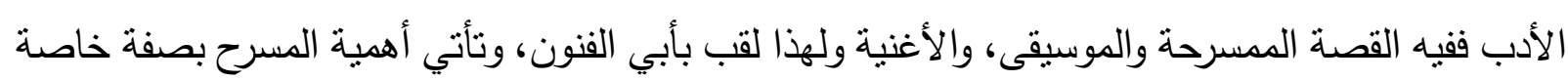

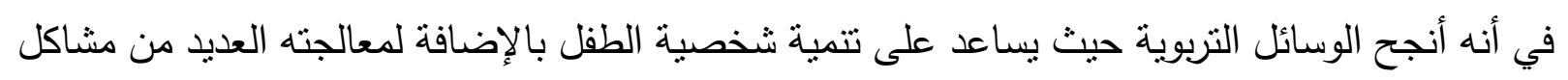

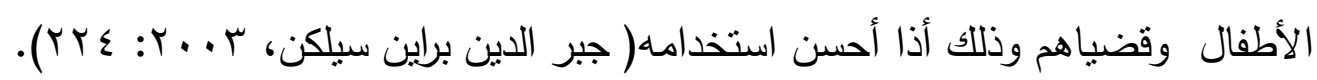

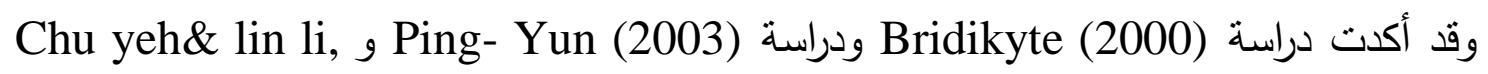
(2008) أن عرض المسرحيات بساهم في نتمية القيم الثقافية ومهارات القراءة والكتابة لدى الأطفال ويزيد

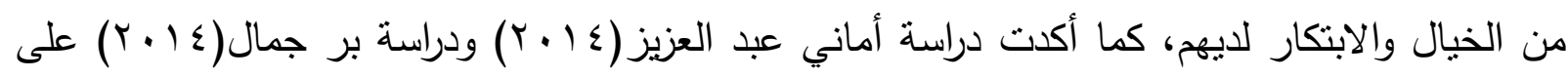

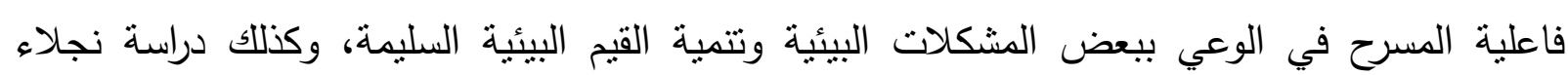

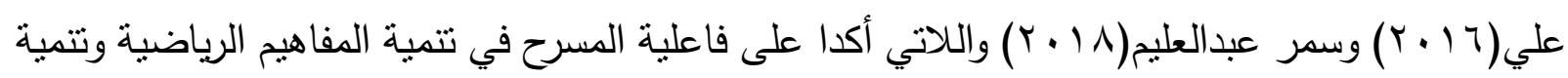
بعض جوانب والإحساس بالمسئولية لدى طفل الروضة. وقد ظهرت أهمية المسرح من كونه أقوى معلم للأخلاق وخير دافع إلى السلوك الحسن، فرولة فهو يعلم

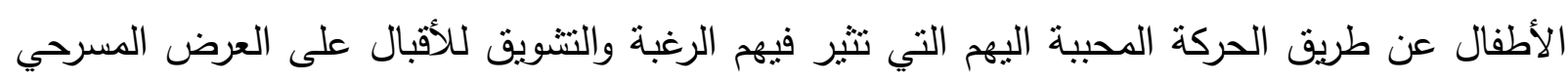

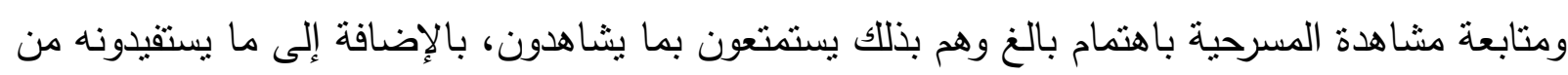

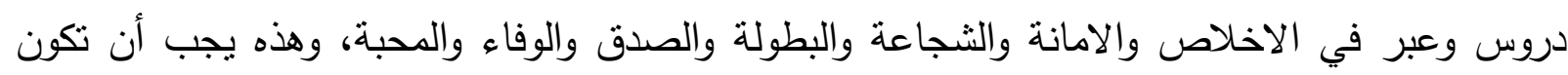

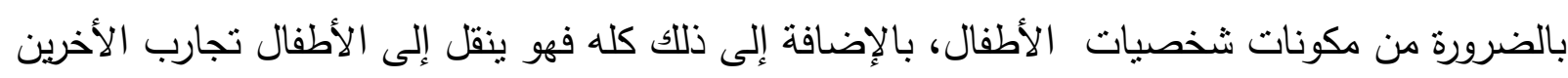

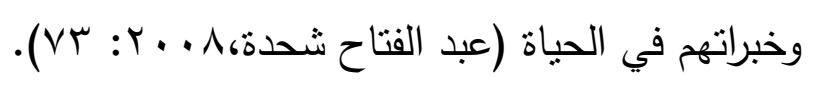
ويجب أن تبنى المسرحيات على أسس تربوية سليمة في ضوء أهداف واضحة، والمات والمسرحية الناجحة هي التي تحاكي قدرات الأطفال وحاجاتهم طبقا للمرحلة العمرية، ويتوقف نجاح المسرحية على أنها تعتىد على جودة الفكرة المُعبر عنها بالكلمة والعبارة السهلة والجو اللغوي المحبب للطفل وكذلك تعتمد على الهذف الواضح الذي يتحدد تبعًا لنوعية المسرحية، ومايميز المسرحية الناجحة هو عنصر التشويق المُستمد من فكرة المسرحية وموضوعاتها، ومن التثثيل المصاحب الأداء الجيد والحركات التعبيرية ومن التجهيزات

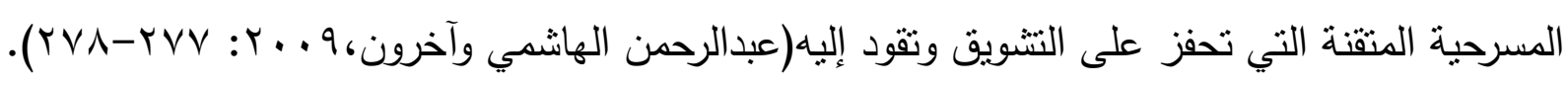




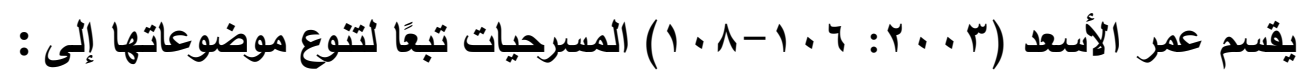

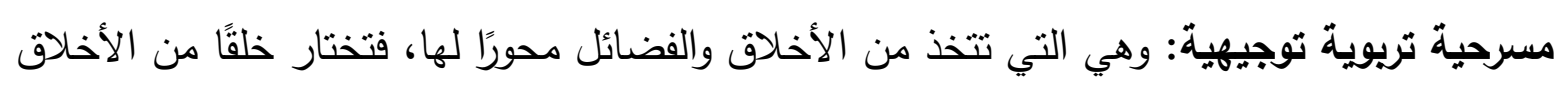

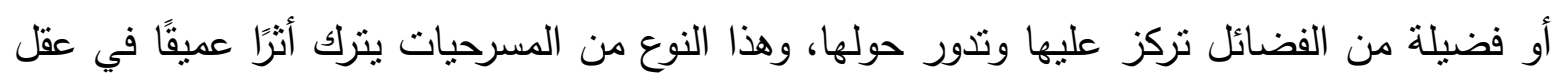

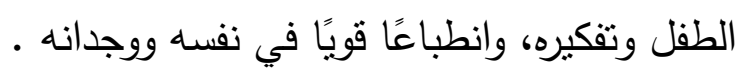

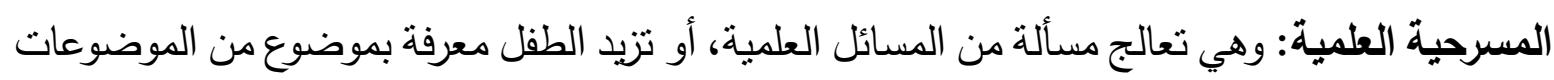
العلمية، فهي بمثابة وسيلة إيضاحية معينة تناعد في إفهام الطفل.

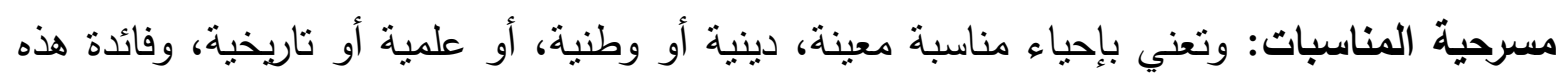
المسرحيات تذكير الأطفال بالمناسبات المرتبطة بها لتبقى حيه في نفوسهر.

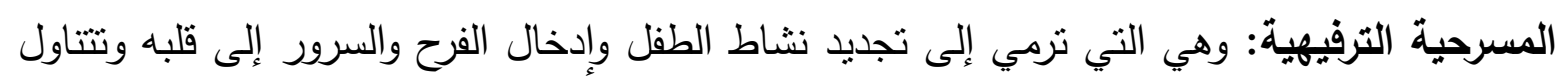
مواقف فكاهية ضاحكة . المسرحية التاريخية :وهي التي تتخذ موضوعها من حادثة تاريخية أو شخصية شهيرة، فيتعرف الطفل الحادثة التاريخية من قريب فيلم بتفاصيلها ويتعرف على جوانب مختلفة من الحياة الاجتماعية السائدة

$$
\text { في العصر الذي تجري فيه أحداث المسرحية . }
$$

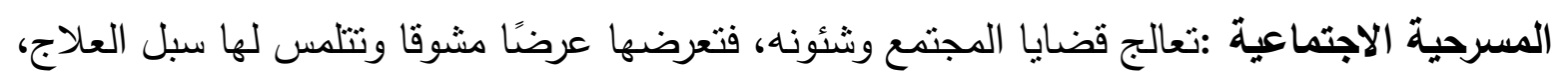
وهو إسلوب عملي مشوق في تعريف الطفل بواقعه الذي يعيشه، ومجتمعه الذي ينتمي إليه ومشكلاته التي تواجها وكيفية حلها والتغلب عليها. المسرحية الثعرية :وهي التي تتطرق إلى قصة شعرية ترمي إلى أهداف لغوية تتصل بتذوق لغة الثعر

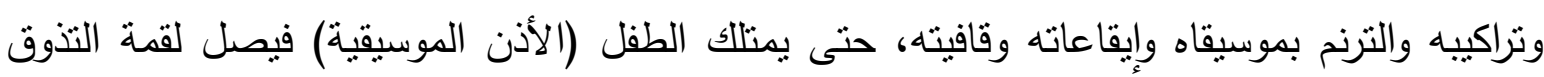
الفني. وتستخلص الباحثة مما سبق ان المسرحيات تُعد من الوسائل التثقيفية التي تكسب الطفل العديد من

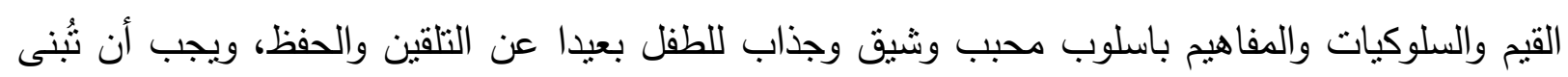

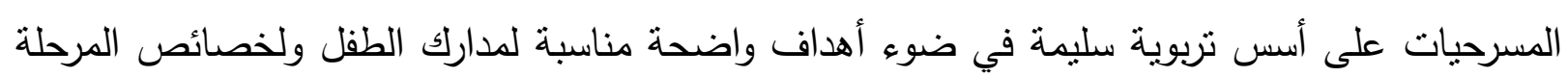
العمرية للمتلقي. ثالثًا: أغاني وأناشيد الأطفال

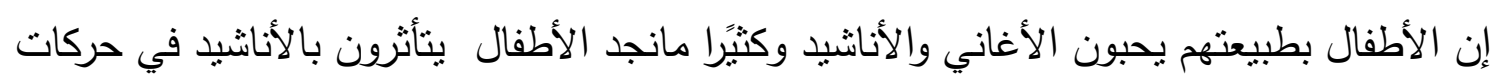
أجسامهم وتصفيق أيديهم ورفع أصواتهم فهي منبع لنشاطهم و لسرورهم، وتعنبر الأغاني والأناشيد من ألوان الأدب التي تمكن الطفل من الاستمتاع باللغته وتتثير في نفسه مشاعر الإحساس المبكر بمظاهر الجمال اللغوي مما يساهم في تطور النمو اللغوي لاى الطفل. 


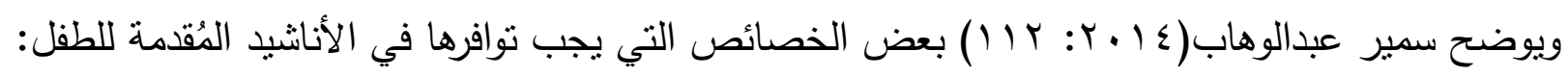
المعاني البسيطة المنصلة بحياة الطفل.

• إسلوب سهل، الفاظه واضحة وجمله خفيفة المعنى.

كلماته تبعث الحماس في نفس الطفل.

ونظرا للقيمة الكبيرة والأهمية البالغة للأغاني والأناثيد فيجب أن تساير أغاني الأطفال الانفعالات الوجدانية

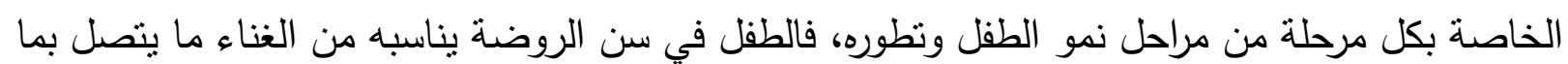

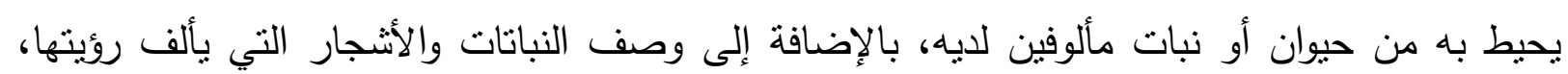

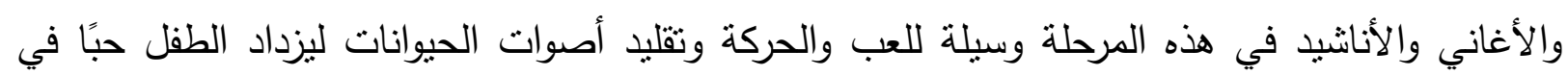

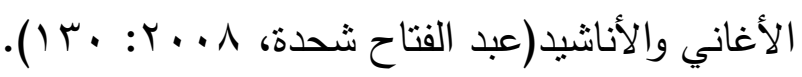

$$
\begin{aligned}
& \text { أهمية الأغاني والأناشيد للأطفال: } \\
& \text { وسيلة للأمتاع والترفية للطفل. } \\
& \text { وسيلة للتعبير عن انفعالات الطفل. } \\
& \text { وسيلة للسمو بحس الطفل الفني. }
\end{aligned}
$$

معالجة الخجل والتلعثم عند الأطفال وتعليمهم النطق الجيد للحروف والكلمات(سمير عبدالوهاب،

$$
\text { (1) } 1 \text { - I) } r \cdot \text { : } 1 \leq
$$

يساعد الطفل على فهم ثقافة المجتمع الذي يعيش فيه.

$$
\text { ينمى الثروة اللغوية. }
$$

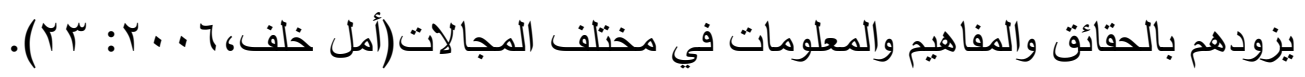

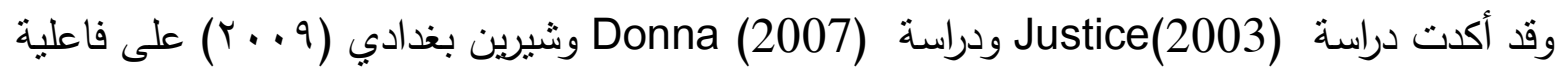
استخدام الأنشطة الموسيقية في تتمية المهارات اللغوية وإثراء المفردات اللغوية لدى الطفل، كما أكدت دراسة

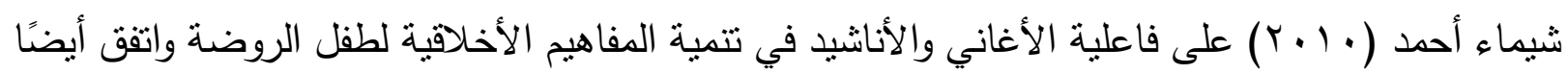
مع هذا دراسة هبة هاشم(7 ( • Y) التي أكدت على فاعلية الأغاني الثعبية في تتمية بعض المفاهيم الاجتماعية

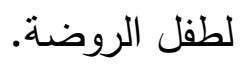

أدب الأطفال و نظرية التعلم الاجتماعي دـ "ألبرت باندورا" تؤكد نظرية باندورا على الدور الفعال للملاحظة والنماذج والقدوة في تعلم الطفل، حيث يميل الطيل الطفل

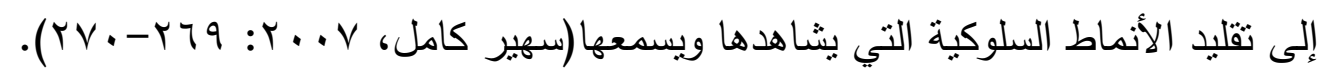
والطفل عندما يرى أو يسمع أنثال الأدب في صورة المتتوعة كقصة أو مسرحية أو أغنية يتفاعل معه

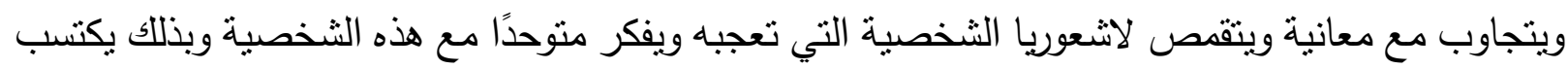

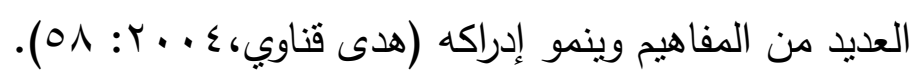


وفي برنامج البحث استخدت الباحثة عدة أنشكال لأدب الطفل مابين القصة والمسرحية والأغاني

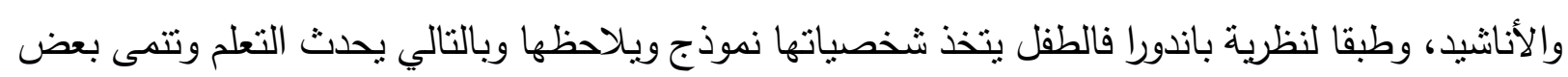
المفاهيم البيولوجية لديه.

\section{المبحث الثاني: المفاهيم البولوجية لائه}

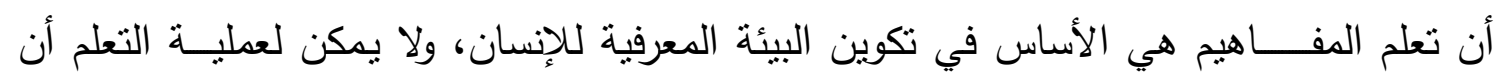

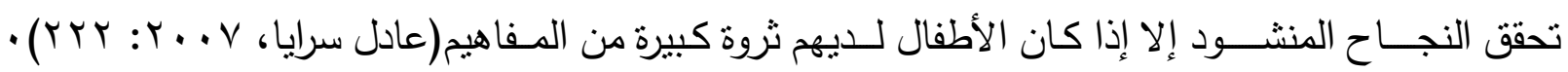

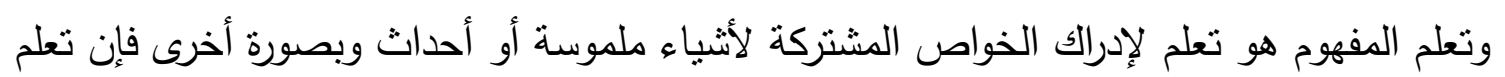
المفهوم يتضمن تصنيف الأشياء في فئات وفقًا لخصائصها المشتركة والاستجابة للخاصية المشتركة (عادل

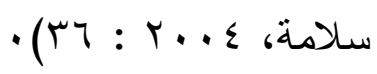

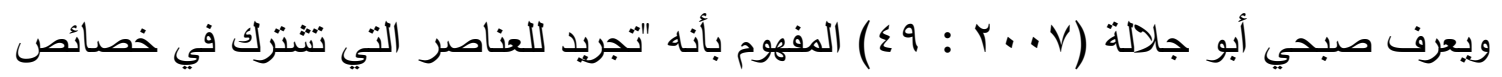

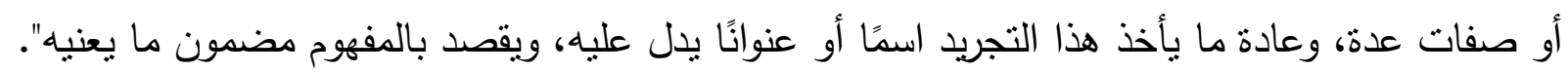

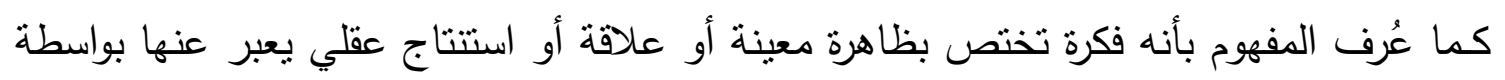

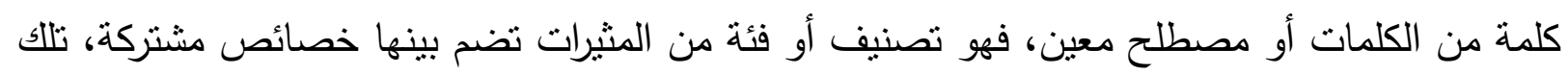

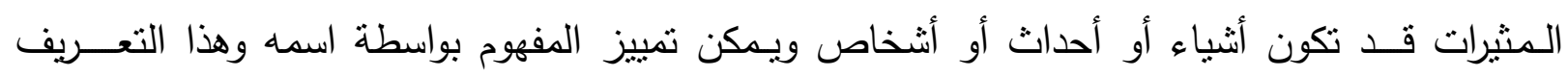

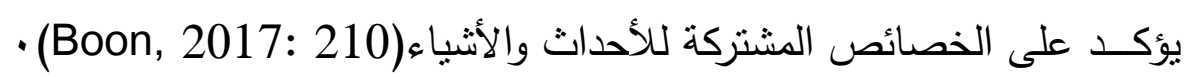
ويُعد تكوين المفاهيم أساسًا في فهم عناصر المعرفة العلمية من مبادئ وقوانين، فبناء المفهوم وتكوينه

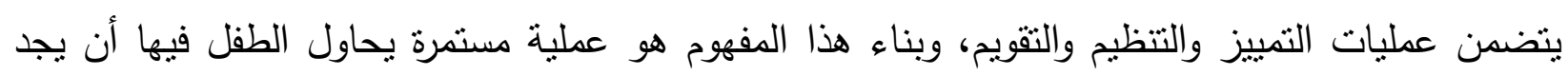

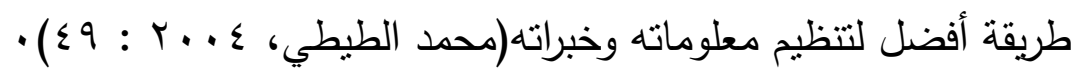
والخبرات التي يمر بها الطفل تعتبر عامل هام بسهم في تكوين المفهوم، حيث تسهم الخبرات في تكوين المفهوم بشكل أيسر ، والطفل يكتسبها من خلال التفاعل المستمر بينه وبين كل ما يحيط به من أفراد وأحداث

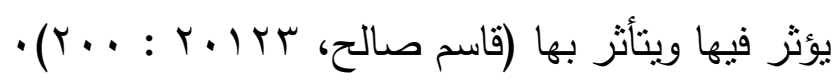
وتستخلص الباحثة مما سبق أن المفاهيم تُساعد على عملية تتظيم الخبرات التي يكتسبها الطفل في

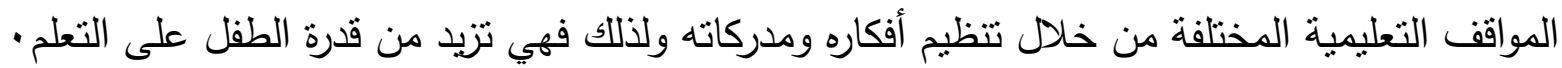

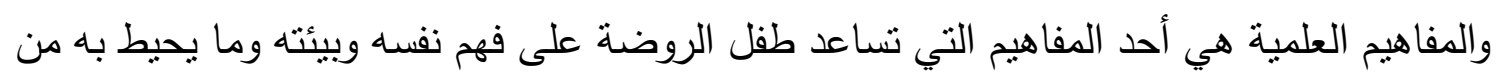

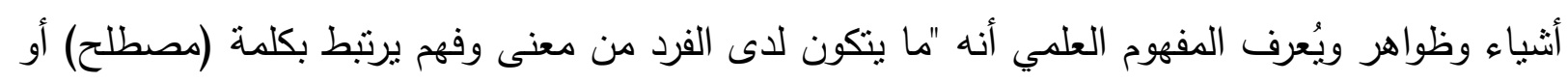

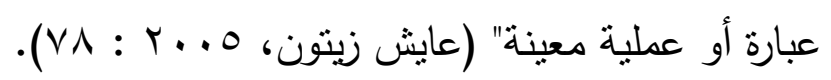

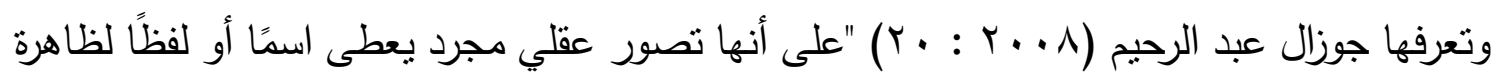

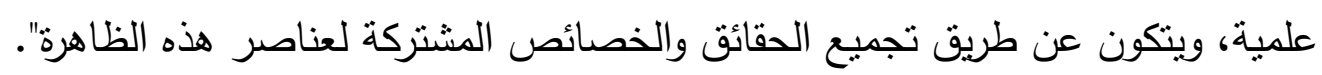


وينمو المفهوم من خلال نضج الطفل ونمو خبراته منذ بداية تعلمه حيث أن المفهوم ليس شينًا ثابنًا في ذاته فالمفاهيم العلمية ومنها البيولوجية تتطور نتيجة لنمو المعارف والحقائق العلمية (عادل سلامة،

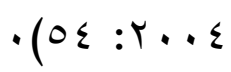

\section{أهمية تعلم المفاهيم العلمية للطفل}

أن المفاهيم العلمية التي يتعلمها الطفل يجب أن تكون مرتبطة بحياته حتي يتقبلها ويجب أن نساعده في حل مشكلات حياتية وتجيب عن استفساراته لما يحيط به في بيئته ويستطيع أن يفهم من خلالها أن لكل الكل شئ سبيًا وهدفًا. ويؤكد برونر أن تعلم الأطفال المفاهيم العلمية تساعدهم على فهم وتفسير كثير من الأشياء التي تثثير

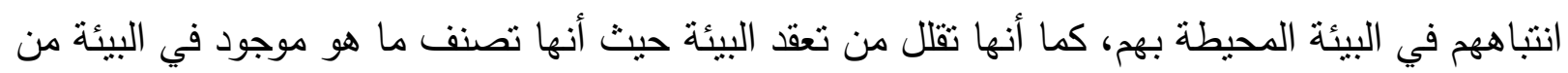

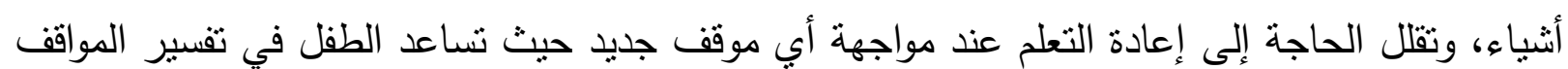
الجديدة أي أن تعلم المفاهيم يساعد على انتقال أثز التعلم، وتساعد على التخطيط والتفسير والتتبؤ (بطرس

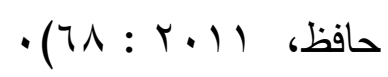

\section{مراحل تكوين المفهوم لدي الطفل}

يفسر بياجيه عملية تعلم المفاهيم العلمية حيث يرى بياجيه أن المعارف أبنية أو تراكيب عقلية وهي الئي أنظمة ذات علاقة داخلية، وهذه البنية للتراكيب هي قواعد التعامل مع المعلومات والأحداث، وينت عن طريقها

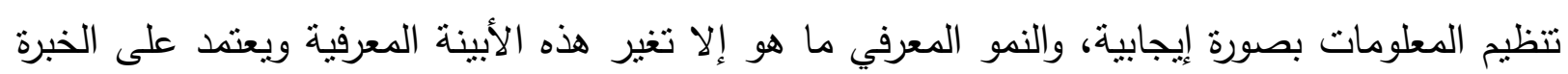
ويتم ذلك أساس آليتين عقليتين متكاملتين هما : التمثيل والمواءهة. ويقصد بالتمثيل امتصاص الطفل للخبرات الجديدة وتوزيعها على التراكيب العقلية المنظمة سابقًا بطريقة

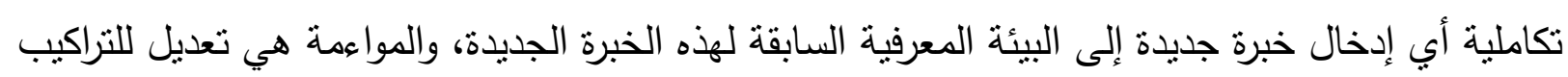
العقلية طبقا للخبرات الجديدة، فالطفل يواجه الموقف التعليمي ويتمنل الموقف الجديد أي يجعله مثل ما لديه

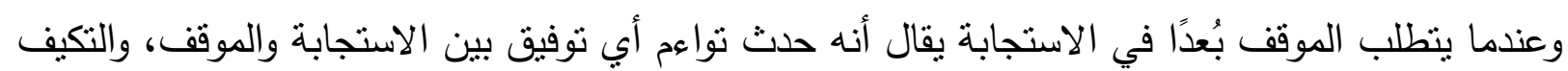

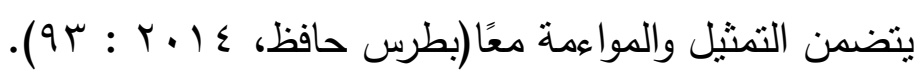

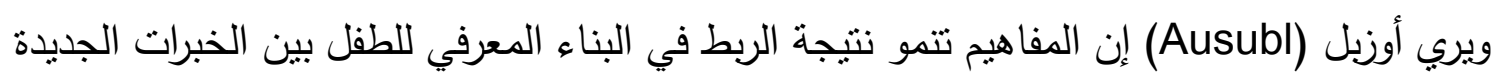

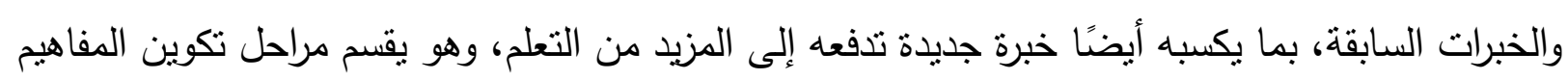

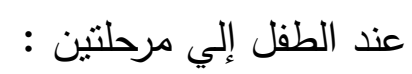
1- المرحلة الأولي: مرحلة تشكيل المفاهيم من خلال الاستكثاف لعدد كبير من المفاهيم والصفات المميزة لها التي تتدمج لتتكيل الصورة الذهنية للففهوم، وتتمو من خلاد الخبرات والتدريب.

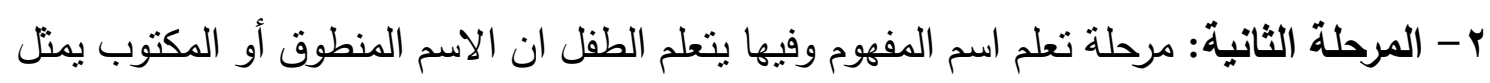

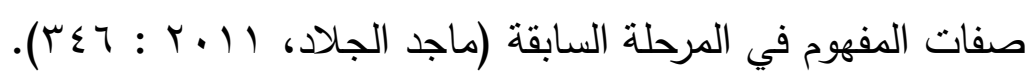


وتعتبر المفاهيم البيولوجية من المفاهيم العلمية الهامة التي ينبغي مراعاة الخطوات السابق ذكرها في

تتميتها للطفل.

وقد راعت الباحثة تلك الخطوات في إعداد البرنامج أثناء تقديم الدفاهيم البيولوجية فبدأت من الخبرات التي يعرفها الطفل وتدرجت مع الطفل إلى الخبرات الجديدة حول الدفاهيم البيولوجية ليتعرف على حقائق البئق وخصائص الكائنات الحية وعلاقتها مع بعضها ومع البيئة التي يعيش فئها. ويشير (32 : Robertson, 2009 أن المفاهيم العلمية جزء رئيسي من الحياة اليومية للطفل، ويعتمد تعلمها على مساعدة الطفل على كيفية البحث بنفسه وكيفية ملاحظة تفاصيل الأشياء وكيفية توجيهه

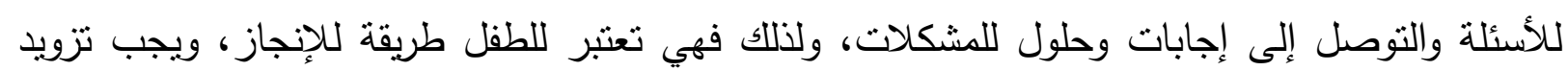

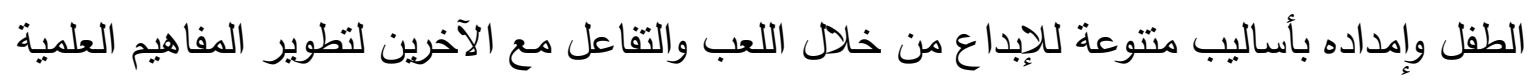

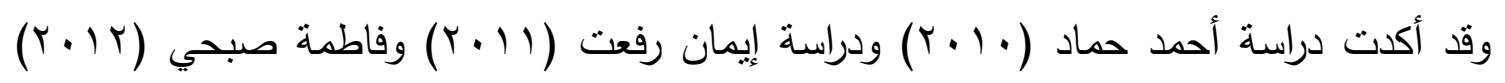

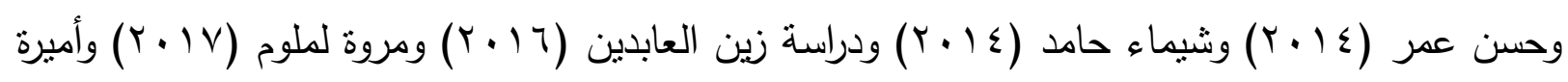

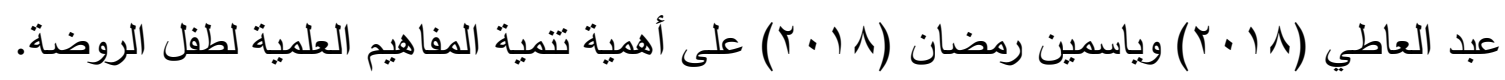

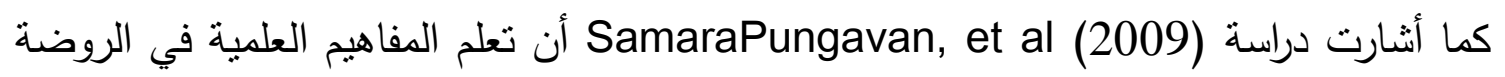
لها أهية كبيرة حيث تشبع حب الاسنطلاع والاستكثاف لدي الطفل وتجيب عن العديد من تساؤلاته.

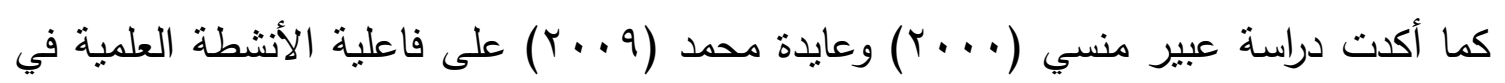

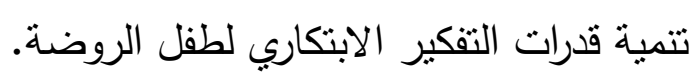
وتعتبر المفاهيم البيولوجية من الدفاهيم العلمية الهامة التي يجب الاهتمام بها وتتميتها لدى طفل

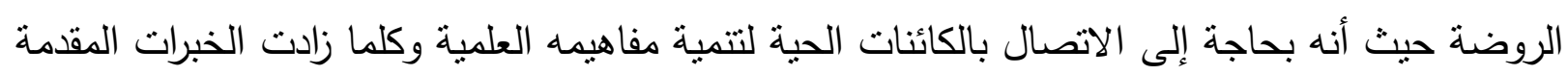

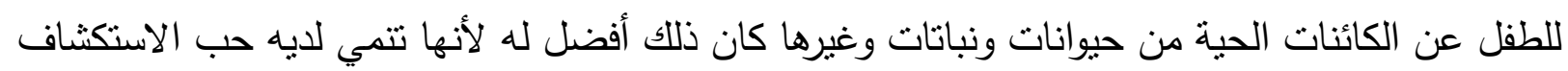

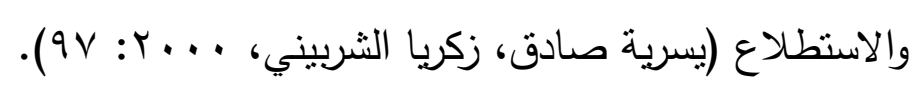
وقد أثبتت دراسة (2006) Tarlowski على أن نشأة التفكير البيولوجي لدى الطفل ينوقف على خبراتهم التي يمرون بها. و يشير (Harlen, 2000 ( 200 إلى أن الدفاهيم البيولوجية تساعد في نمو وتطوير تفكير الأطفال لأنها تثير تفكيرهم وتربطهم بالبيئة المحيطة بهم.

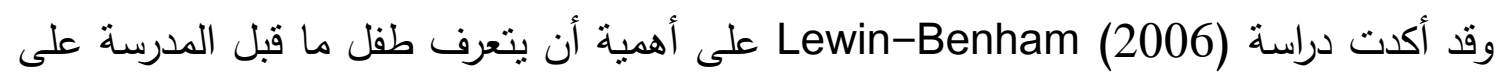
البيئة بما تضمنه من كائنات حية من حيث نوعية الحياة في كل من النبات والحيوان والإنسان وكيفية التفاعل 


\section{تعريف المفاهيم البيولوجية:}

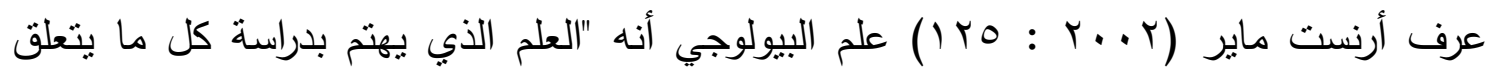

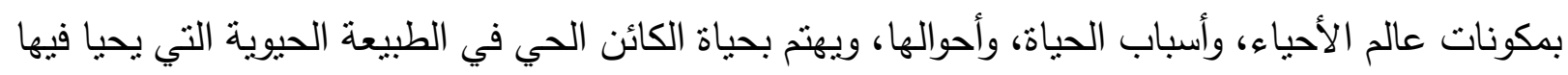

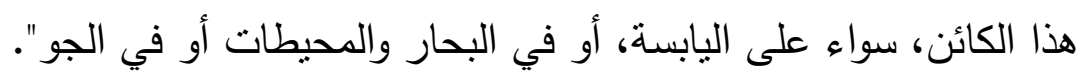

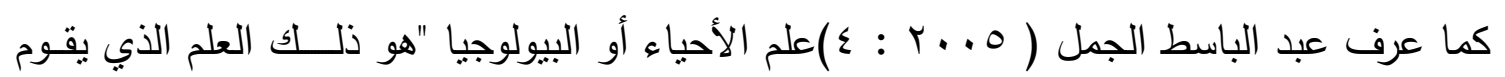

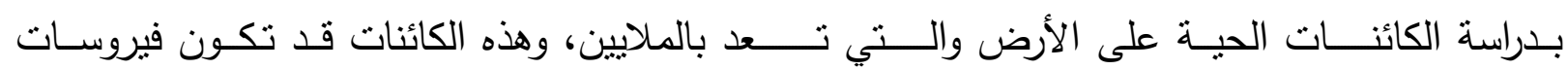
أو بكتيريـا أو نباتات أو حيوانـات أو إنسـانًا".

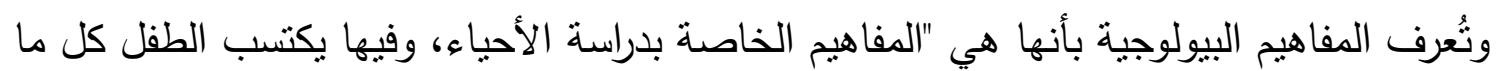

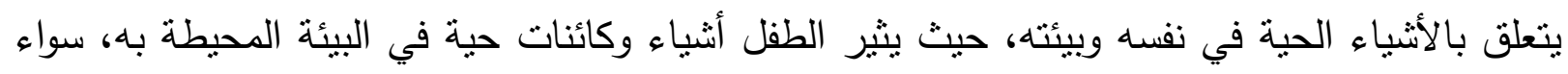

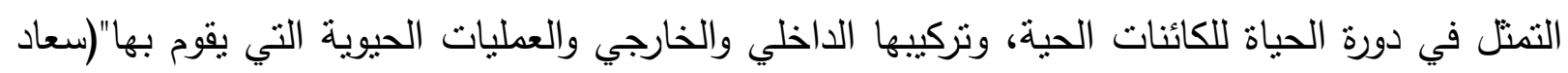

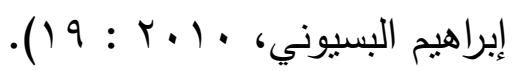

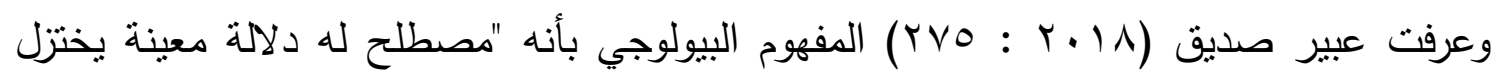

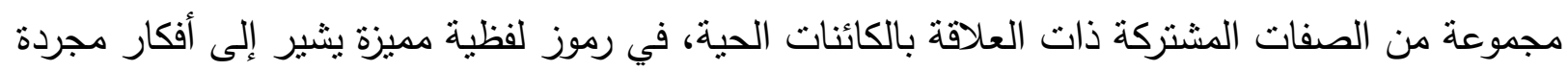
حول فئة من الموضوعات ذات العلاقة المشتركة". وقد عرفته الباحثة إجرائياً بأنه:

استتناجات عقلية يصل إليها الطفل ويكونها من خلال دراسة الحقائق المرنبطة بالكائنات الحية من حيث شكلها وتركيبها، ودورة حياتها وتُعطى مصطلحًا أو اسمًا للتعبير عنها.

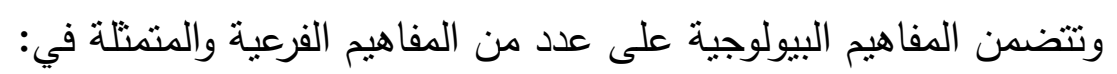

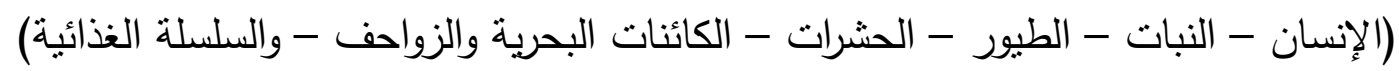

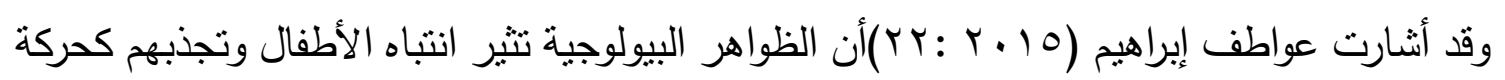

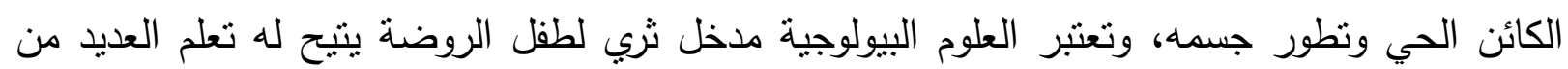
الحقائق والمهارات. ويؤكد بياجيه أن هناك مستويات لتفسير الأطفال علَيه الظواهر البيولوجية وتتدرج هذه المستويات مع

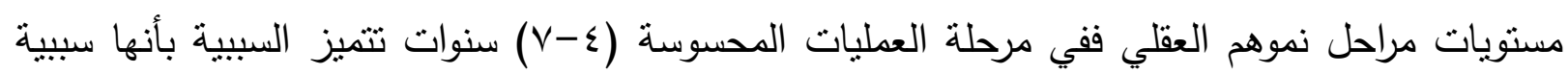
بسيطة، سبيية ربط أفعال الطفل بنتائجها على الأثباء بمعنى أن بصبح الطفل قادر على على أن يتصور العلاقة العليَّة بين أفعاله التي قام بها ونتائجها على الأثنياء. ومن خلال الظواهر البيولوجية للحيوان والنبات تتمو المهارات المتعلقة بمفهوم العليَّة لدى الطفل فمن لئل

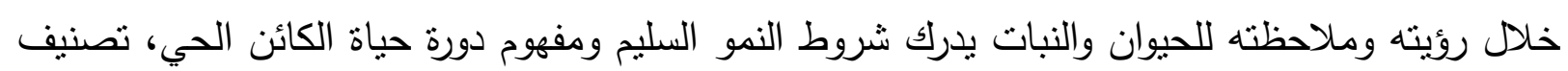

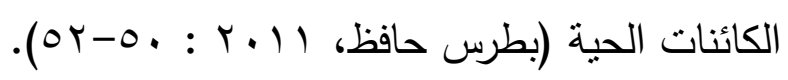


وقد أكلت الباحثة في أنثطة البرنامج على مفهوم العليَة وذللك من خلال توضيح وشرح شروط النمو السليم للكائنات الحية كالنبات وما يحتاجه من (ماء - شمس - تربة - هواء) للنمو والإنبات، أيضًا توضيح مفهوم دورة حياه الكائن الحي وفهم السلسلة الغذائية للكائنات الحية، والتمييز بين خصائص الكائنات الحية

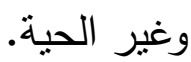

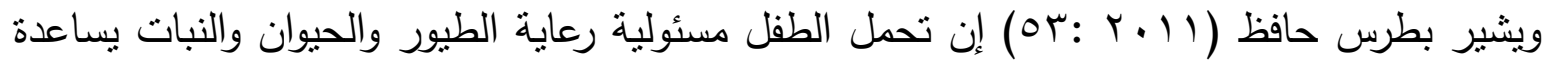
في إدراك مفهوم دورة حياة الكائنات الحية ونوعية غذائها وتصنيفها. وقد أكدت دراسة Humphryes أن اهتمام الطفل ورعايته للكائنات الحية كالحيوانات الأليفة والأسماك والنبات يعطي الطفل فرصة لتحمل المسئولية ويبني ثقة الطفل بذاته.

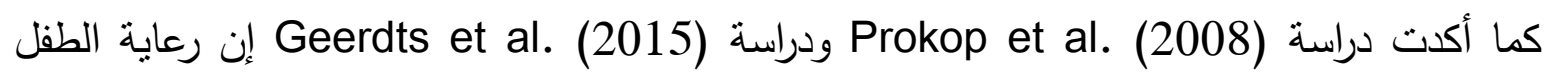
للحيوانات الأليفة يكسبه العديد من المعلومات البيولوجية حول خصائص الحيوان وأجزاء جسمه ودورة حياته ومراحل نموه. وبشأن هذا الصدد فقد أكدت دراسة كلاً من Robinson و مور دراسة إملي صادق وابراهيم

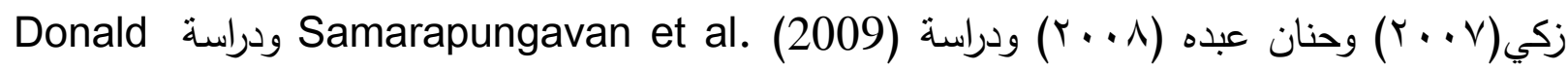

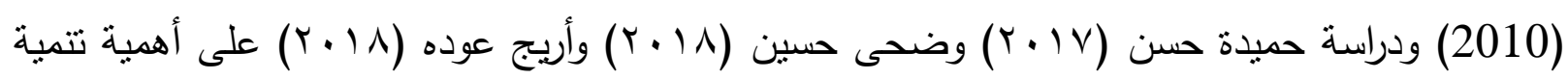
الكفاهيم البيولوجية لاي طفل الروضة.

\section{خصائص المفهوم البيولوجي:}

حيث أن الدفاهيم البيولوجية إحدى المفاهيم العلمية فهي تتميز بمايلي:

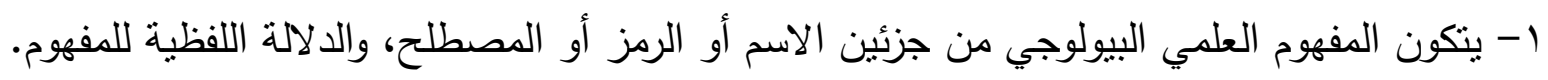

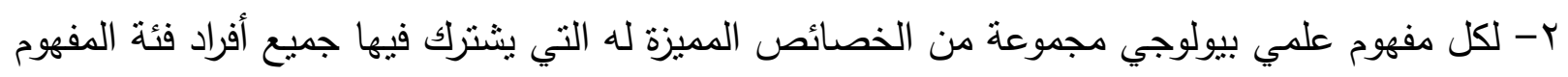

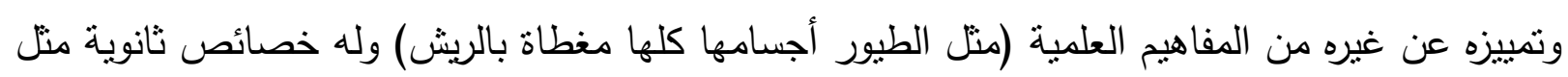
الاختلاف في المناقير والرجل والرقبة.

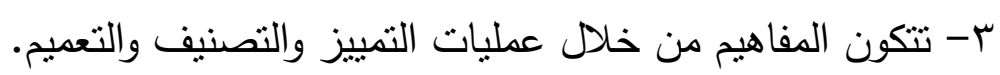
ع - تكوين المفهوم العلمي البيولوجي عملية مستمرة فيتندج في الصعوبة من مرحلة تعليمية إلى أخرى ومن الغموض إلى الوضوح، ومن المحسوس إلى المجرد ومن مفهوم علمي غير دقيق إلى مفهوم علمي دقيق الفيق

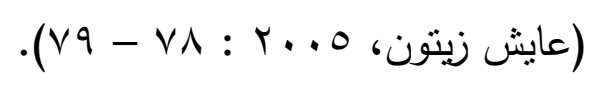

\section{تستخلص الباحثة مما سبق:}

"أن المفاهيم البيولوجية تسهل على الطفل التعامل مع البيئة لأنها تضم مجموعة من الأثياء في اسم واحد فقط وهو "اسم المفهوم البيولوجي". * ت تساعد في التعلم بشكل سليم. 
* تقلل من الحاجة إلي إعادة التعلم فالمفهوم الذي يتعلمه الطفل يستخدمه مرات عده في المواقف التعليمية دون الحاجة لتعلمها من جديد. * تتظم خبرات الطفل وتناعد على تتظيم المعلومات المتتوعة وتصنيفها بشكل يساعد على فهم العلاقات المتبادلة بينهم وجعلها ذات معني.

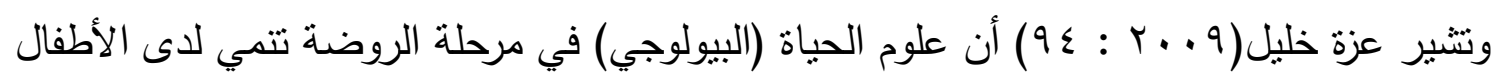

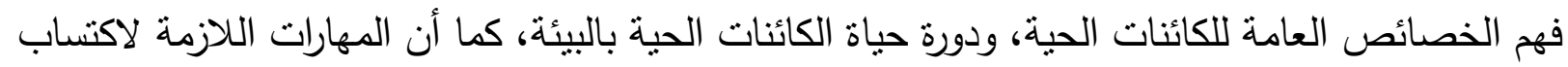

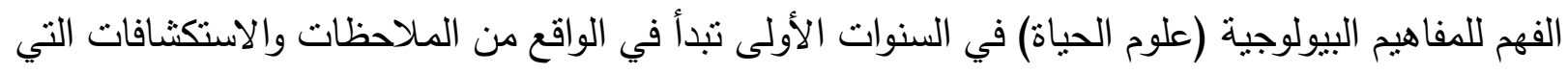

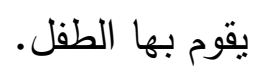
والطفل في سنوات عمره المبكرة يكون شغوف بالتعرف على الكائنات الحية التي يراها من حوله،

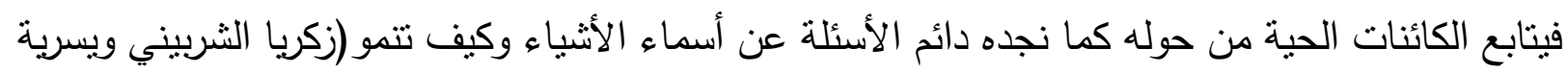

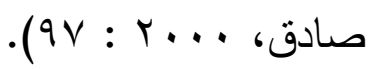
وفي هذا الثأن قد أكدت دراسة (2018) Fusaro \& Smith على أن طفل ما قبل الدراسة يحاول

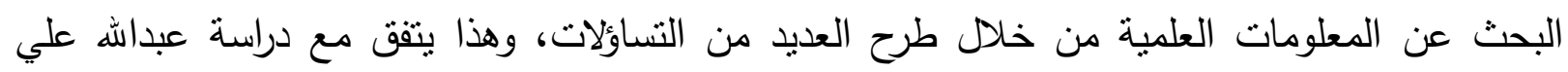

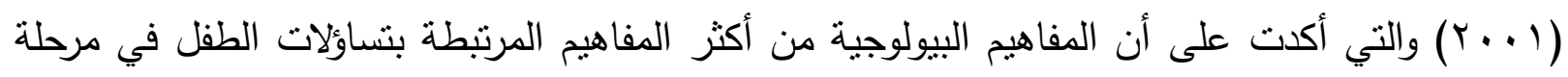

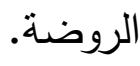

كما أثنتت دراسة (2014) . Decoster et al أن دراسة الطفل للمفاهيم البيولوجية تساعده على الإجابة عن العديد من النساؤلات لديه المرتبطة بالكائنات الحية. وفي هذا الثأن أكد (2006) Seefeldt \& Gapler على أهية دراسة الطفل للعلوم البيولوجية التي تهتم بدراسة الكائنات الحية من علم حيوان ونبات؛ حيث يمارس الطفل عمليات العلم (كالملاحظة الهن والتصنيف والإسنتناج) أثناء فحصهم الكائنات الحية، وتتطور لديهر مهارات التفكير وحل المشكلات. Mahtzicopoulos et al. ودراسة Gelman \& Brenneman (2004) وقد أكدت دراسة ولأسة

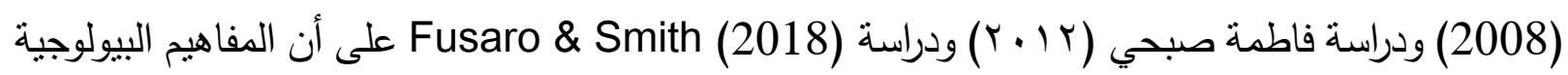
تتمي مهارات التفكير العلمي لدي الطفل (كالفهم والتتبؤ والملاحظة وجمع الأدلة والاستتناج وحل المشكلات والتفسير )

\section{وتستخلص الباحثة مماسبق :}

أن المفاهيم البيولوجية تهنم بدراسة الكائنات الحية بمختلف أنواعها وأنثالها لمعرفة الحقائق عنها

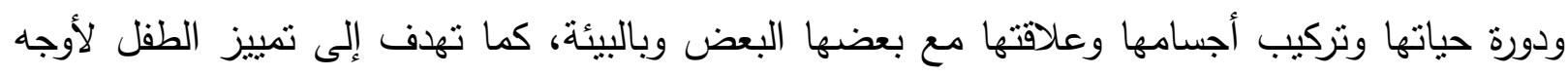
الاختلاف بين الكائنات الحية وغير الحية وبذلك فهي تناعد الطفل على التفكير وتفسير كثير من الأثياء

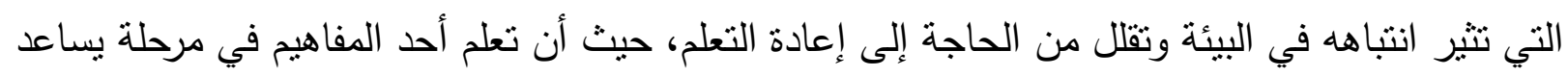
على تقسير الموقف الجديد. 


\section{الإجراءات المنهجية للبحث}

تتمثل الإجراءات المنهجية المتبعة في خطوات وإجراءات البحث وتتــــمل على المنهج والأدوات المستخدمة، والدراسة الميدانية وكذلك الأساليب الإحصائية لمعالجة البيانات.

أولاً: منهج البحث

اسـتخدمت الباحثة المنهج شـبه التجريبي لمناسـبته لطبيعة هذا البحث وذلك باسـتخدام التصـميم

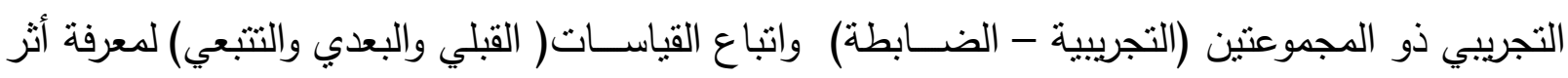
المتغير المستقل ( أدب الأطفال ) على المتغير التابع (المفاهيم البيولوجية). جدول (1)

يوضح التصميم التجريبى والقياسات القبلية والبعدية والتتبعي لمجموعات البحث.

\begin{tabular}{|c|c|c|}
\hline المجموعة الضابطة & المجموعة التجريبية & القياسات المستخدمة مجموعات الدارسة \\
\hline$\sqrt{ }$ & $\sqrt{ }$ & القياس القبلي \\
\hline$\sqrt{ }$ & $\sqrt{ }$ & برنامج الروضة \\
\hline$x$ & $\sqrt{ }$ & أنشطة أدب الأطفال \\
\hline$\sqrt{ }$ & $\sqrt{2}$ & القياس البعدي \\
\hline$x$ & $\sqrt{ }$ & القياس التتبعي \\
\hline
\end{tabular}

ثانياً: مجتمع وعينة البحث

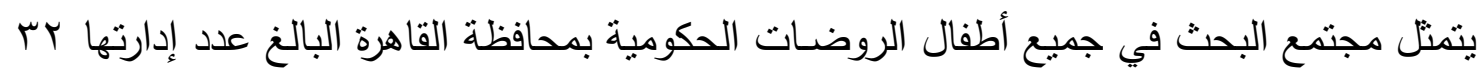
إدارة تعليمية وقد تم اختيار روضة"الثهيد أحمد حمدي" بمدرسة الثهيد أحمد حمدي الابتدائية والتابعة لإدارة

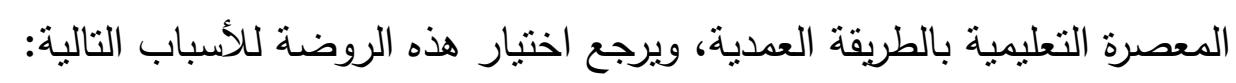

$$
\text { •ترحيب إدارة الروضة والعاملين بها وتعاونهم مع الباحثة. }
$$

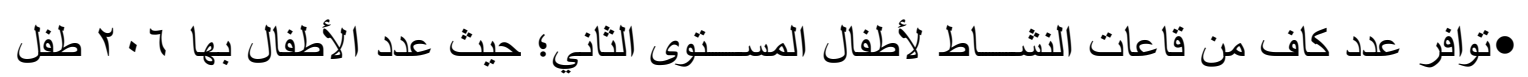

$$
\text { لضمان إمكانية الحصول على العينة. }
$$

وبلغ عدد أطفال عينة البحث إلى (•r طفلًا وطفلة) للمجموعة التجريبية، و(·ـ طفلًا وطفلة )

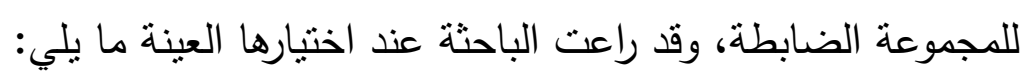

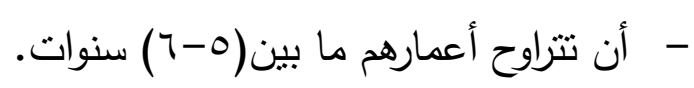

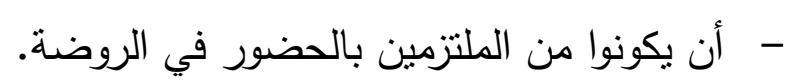
- أن لا يعانون من أى مشكلات صحية أو إعاقات جسمية تمنعهم من الحضور للإنة للروضة. 
تجانس العينة

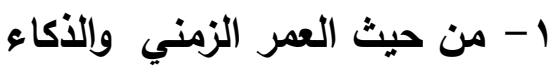

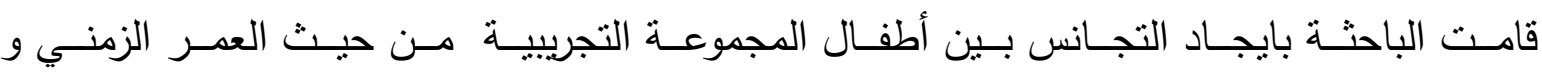

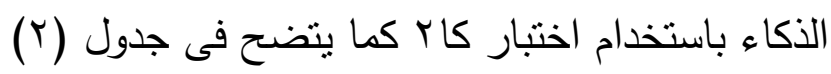

جدول (r)

التجانس بين أطفال المجموعة التجريبية من حيث العمر الزمني و الذكاء

$r \cdot=ن$

\begin{tabular}{|c|c|c|c|c|c|}
\hline \multicolumn{2}{|c|}{ حدود الدلالة } & \multirow[t]{2}{*}{ درجة حرية } & \multirow{2}{*}{ مستوى } & \multirow[t]{2}{*}{ كاי } & \multirow[t]{2}{*}{ المتغيرات } \\
\hline., .0 & $\cdot, .1$ & & & & \\
\hline $19, v$ & $r \leqslant, V$ & 11 & غير دالة & $\Lambda, \varepsilon$ & العمر الزمني \\
\hline$r 1, \xi$ & $r v, \tau$ & r. & غير دالة & 0 & الذكاء \\
\hline
\end{tabular}

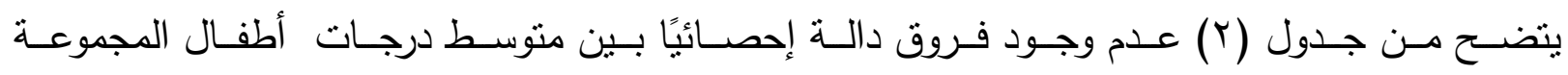

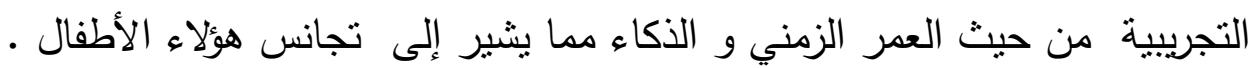

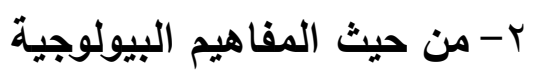

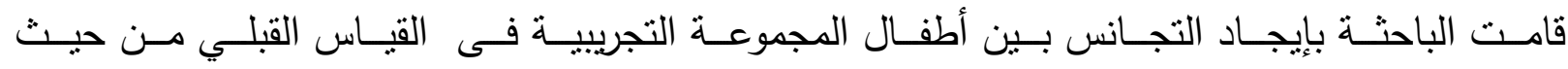
الدفاهيم البيولوجية كما يتضح فى جدول (r) بايجن

جدول (r) ( )

التجانس بين أطفال المجموعة التجريبية فى القياس القبلي

من حيث المفاهيم البيولوجية

$r \cdot=\dot{ }$

\begin{tabular}{|c|c|c|c|c|c|}
\hline \multicolumn{2}{|c|}{ حدود الدلالة } & \multirow{2}{*}{ درجة } & \multirow{2}{*}{ مستوى الدلالة } & \multirow[t]{2}{*}{ كاr } & \multirow[t]{2}{*}{ المتغيرات } \\
\hline., .0 & $\cdot, ., 1$ & & & & \\
\hline$\overline{\nabla, \Lambda}$ & $11, r$ & $\bar{\mu}$ & غير دالة & $\varepsilon, \xi$ & الإنسان \\
\hline$r, \Lambda$ & 7,7 & 1 & غير دالة & $\cdot$, OrT & النبات \\
\hline$r, \Lambda$ & 7,7 & 1 & غير دالة & .,Orr & الطيور \\
\hline 7 & $9, r$ & $r$ & غير دالة & Y, & الحشرات \\
\hline$r, \Lambda$ & 7,7 & 1 & غير دالة & $1, Y$ & الكائنات البحرية والزواحف \\
\hline 7 & $9, r$ & $r$ & غير دالة & $1, \varepsilon$ & السلسلة الغذائية \\
\hline $1 \mathrm{~V}, 0$ & $\overline{r r}$ & 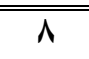 & غير دالة & $1 \cdot, r$ & الارجة الكلية \\
\hline
\end{tabular}

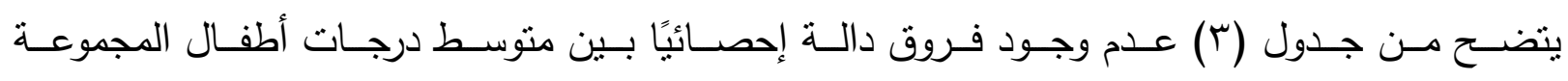
التجريبية فى القياس القبلي من حيث الدفاهيم البيولوجية. 
التكافؤ بين أطفال المجموعتين التجريبية والضابطة

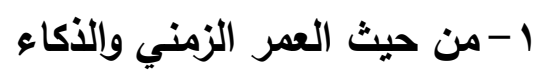

قامت الباحثة بإيجاد دلالة الفروق بين منوسط درجات أطفال المجموعتين التجريبية والضـابطة فى القياس

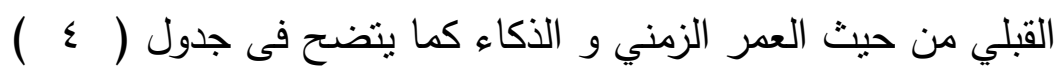

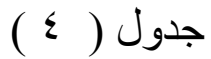

التكافؤ بين أطفال المجمو عنين التجريبية والضابطة من حيث العمر الزمني والذكاء

7 .

\begin{tabular}{|c|c|c|c|c|c|c|}
\hline \multirow[t]{2}{*}{ مستوي } & \multirow[t]{2}{*}{ 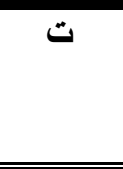 } & \multicolumn{2}{|c|}{ المجموعة الضابطة } & \multicolumn{2}{|c|}{ 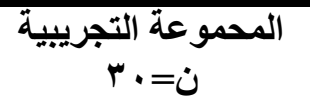 } & \multirow[t]{2}{*}{ المتغيرات } \\
\hline & & re & $T_{p}$ & $1 \varepsilon$ & Ip & \\
\hline غير دالة & $\cdot, 11 \mathrm{~V}$ & $r, r$ & 74,74 & $r, r)$ & 74,04 & العمر الزمني \\
\hline غير دالة &., 9.0 & $V, V \wedge \Lambda$ & 10,17 & $V, r r$ & $1.4, \xi$ & الأذكاء | الذاء \\
\hline
\end{tabular}

يتضـح من جدول (ع) عدم وجود فروق دالة إحصـائيًا بين متوسـط درجات أطفال المجموعتين التجريبية

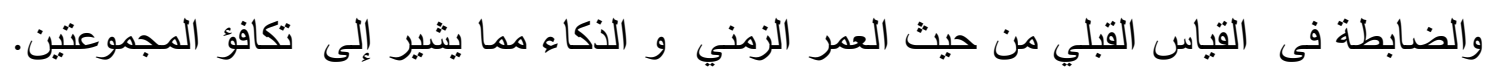
r-من حيث المفاهيم البيولوجية

قامت الباحثة بايجاد دلالة الفروق بين منوســـ درجات أطفال المجموعتين التجريبية والضـــابطة فى القياس

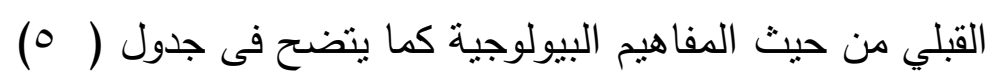

$$
\text { جدول (0) (0) }
$$

التكافؤ بين أطفال المجمو عتين التجريبية و الضابطة

$$
\text { من حيث المفاهيم البيولوجية المجية التجرية }
$$

\begin{tabular}{|c|c|c|c|c|c|c|}
\hline \multirow[t]{2}{*}{ مستوى } & \multirow[t]{2}{*}{ ت } & \multicolumn{2}{|c|}{ المجموعة الضابطة } & \multicolumn{2}{|c|}{ المحموعة التجريبية } & \multirow[t]{2}{*}{ المتغير ات } \\
\hline & & $r \varepsilon$ & $t_{p}$ & $1 \varepsilon$ & $T^{5}$ & \\
\hline غير دالة & $1, r+7$ & $1, r Y$ & $\Lambda, \vee \mu$ & $1,1 r$ & 9,1 & الإنسان \\
\hline غير دالة & $\cdot, Y Y A$ & $\cdot, 7 Y 1$ & $7, \xi$ & $\cdot, 0 \cdot \varepsilon$ & $7, \varepsilon Y$ & النبات \\
\hline غير دالة & $\cdot, 19 \mathrm{~V}$ & $\cdot, \vee \vee \vee$ & 7,OTH & $\cdot, 0 \cdot \varepsilon$ & 7,079 & الطيور \\
\hline غير دالة & $1,1 Y \wedge$ & $\cdot, 7 Y \wedge$ & $v, 1 r$ & $\cdot, \vee \vee q$ & $r, q r r$ & الحشرات \\
\hline غير دالة & $1, r \leqslant 7$ & $\cdot, V Y Y$ & 7,7 & $\cdot, \leqslant 91$ & $7, \xi$ & الكائنات البحرية والزواحف \\
\hline غير دالة & $\cdot, 101$ & $\cdot, \Lambda \cdot 0$ & 7,1 & $\cdot, \wedge r r$ & $\checkmark, \wedge r$ & السلسلة الغذائية \\
\hline غير دالة & $\cdot, \varepsilon \cdot 1$ & $1, \sqrt{1,9}$ & $\overline{\varepsilon Y, Y q}$ & 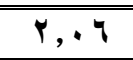 & $\varepsilon Y, \leqslant Y$ & الارجة الكلية \\
\hline
\end{tabular}

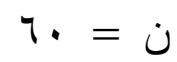

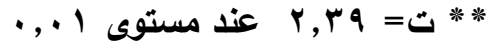

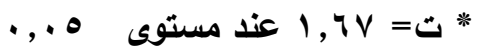


يتضـــح من جدول (0) عدم وجود فروق دالة إحصـــائيًا بين منوســــ درجات أطفال المجموعتين التجريبية والضابطة فى القياس القبلي من حيث المفاهيم البيولوجية مما يثير إلى تكافؤ المجموعتين.

\section{ثالثاً: أدوات البحث}

تستخدم الباحثة في البحث الحالي الأدوات التالية:

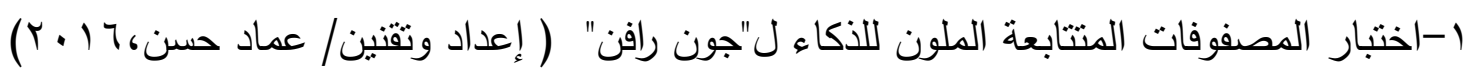
ملحق(ع)

r-استمارة استطلاع أراء السادة المحكمين لتحديد أبعاد "الدفاهيم البيولوجية"، والأثكال الأدبية المناسبة

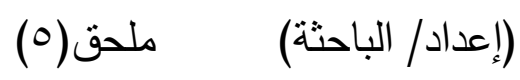
لطفل الروضة.

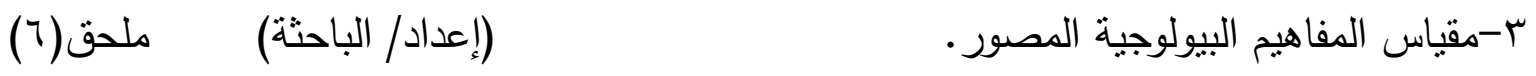

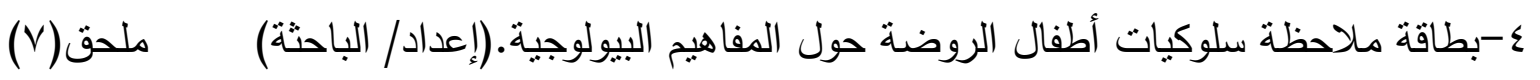

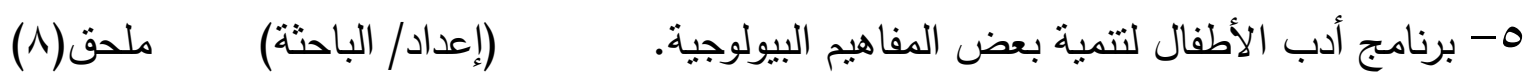

1-اختبار المصفوفات المتتابعة الملون للأكاء ل"جون رافن"

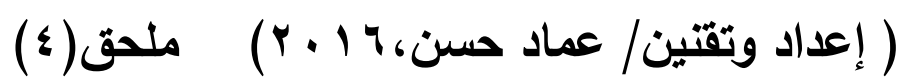

وصف الاختبار:

رأت الباحثة استخدام هذا الاختبار لمالائمته لعمر عينة البحث ويعتبر اختبار المصفوفات المتتابعة

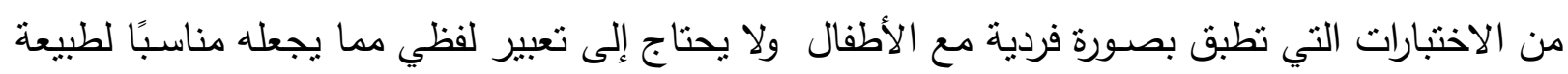

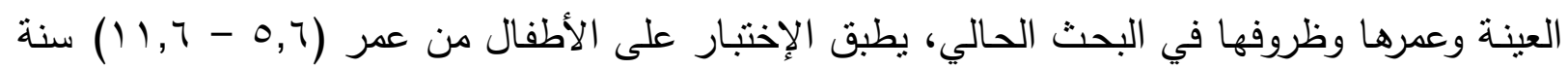

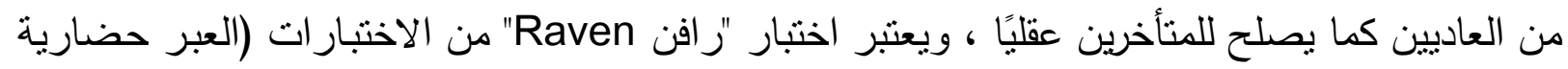
(Cross -Cultural

$$
\text { يتكون هذا الاختبار من (r) مجموعات هي: }
$$

المجموعة (أ): و النجاح فيها يعتمد على قدرة الفرد على إكمال نمط مستمر ، وعند نهاية المجموعة

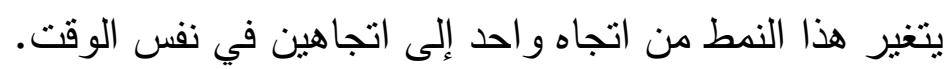

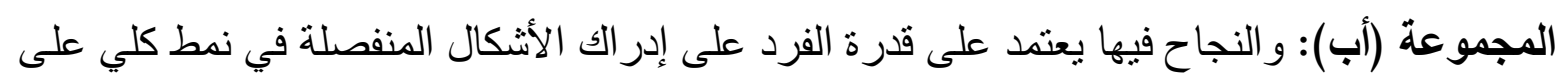
أساس الارتباط المكاني. المجموعة (ب): و النجاح فيها يعتمد على فهم الفرد للقاعدة التي تحكم التغيرات في الأشكال المرتبطة منطقياً أو مكانياً، وهي تتطلب قدرة الفرد فئه على التفكير المجرد. 
وكل مجموعة منها تتكون من "با" مصفوفة كل منها في بطاقة، وكلً منها تحتوي على "ج" مصفوفات صغيرة في أسفلها بحيث يختار المفحوص مصفوفة واحدة لتكون المكملة للمصفوفة التي بالأعلى، كما يُلاحظ أن هذه البطاقات قد صُممت بألوان مختلفة حتى تستطيع تلك البطاقات جذب انتباه الطفل المفحوص بأكبر قدر ممكن بدلا من نشتت انتباهه في أشياء أخرى. يبدأ الفاحص بإعطاء فكرة بسيطة عن المصفوفات ثم يبدأ الفاحص فتح كتيب الاختبار على الثكل الأول ويشير إلى الشكل الأسـاسي في أعلى الصفحة، قائلًا: كما ترى فإن هذا الثكل قطع منه جزء، وهذا الجزء المقطوع موجود في أحد الأجزاء المرسومة تحت الشكل؛ ويشير إلى الأجزاء في أسفل الصفحة واحدًا

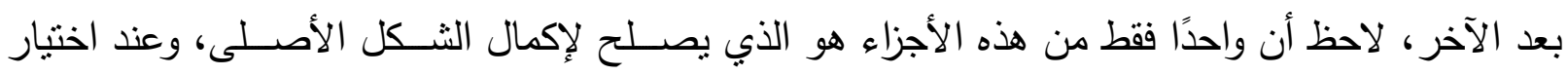
الطفل للثــكل المناسـب تعطى له درجة ( (1) وهكذا حتى ينتهى من كل الاختبار ومجموع درجات الاختبار

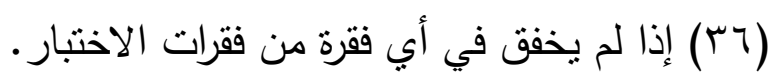

الخصائص السيكومترية للاختبار صدق الاختبار

تم حساب صدق الاختبار بأكثر من طريقة منها الصدق التلازمي حيث تراوحت معاملات الإرتباط بين اختبار المصفوفات المتتابعة الملونة واختبارات أخرى كاختبار وكسلر القسم اللفظي ما بين( اس, . -1 ع, • )،

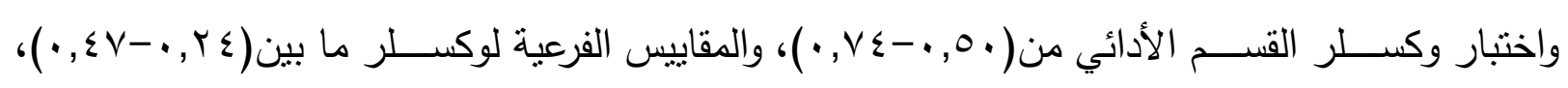

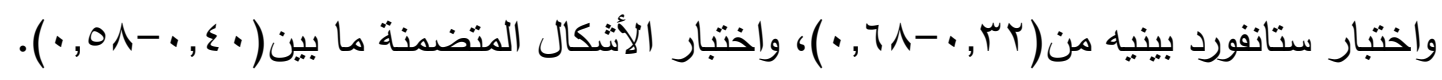

ثبات الإختبار

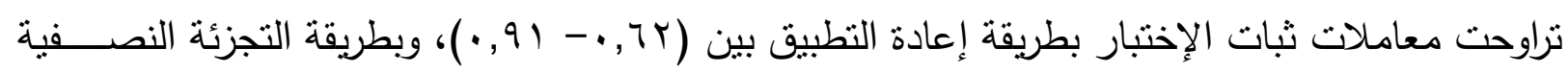
بين (

وقد قام (عماد حسـن، T 1 • Y) بتعريب وتقنين الاختبار على البيئة المصــرية حيث قام بحســاب معاملات

الارتباط بينه وبين اختبارات الذكاء الأخرى باســتخدام الصــدق التلازمي وتراوحت معاملات الارتباط ما بين(اب, . -

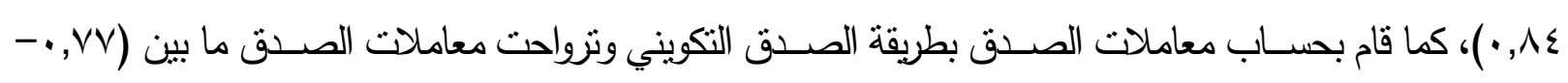
(1, • ) وجميعها قيم عالية ما يدل على صــدق الاختبار، كما قام بحسـاب معامل الثبات باســتخم معامل الاســقفرار وتوصـل إلى معامل ثبات مقداره (01, •)، كما توصـل إلى معامل ثبات بطريقة التجزئة النصـفية مقدراه ( (19 • )، كما

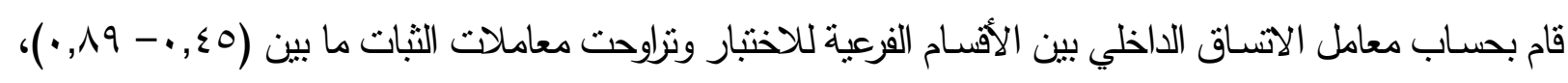
وجميعها قيم ثبات عالية مما يدل على ثبات الاختبار .

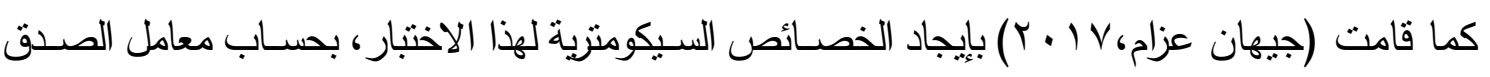
التازمي وبلغت معاملات الصدق ع V, •، وبتقدير معامل التبات بطربقة إعادة تطبيق الاختبار وبلغت معاملات الثبات 
وقامت (علا حسن،9 1 • ب) بايجاد الخصائص السيكومترية لهذا الاختبار، باستخدام الصدق التلازمى لإيجاد معاملات الارتباط بين هذا الاختبار واختبار وكسلر للأطفال فكان معامل الصدق 9 م, ، ، ومعامل الإزتباط مع اختبار

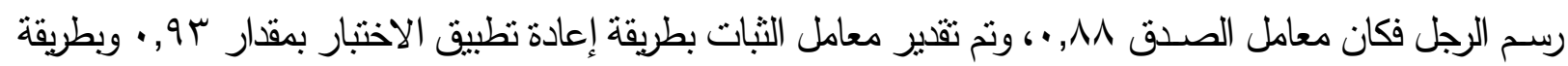
التجزئة النصفية بمقدار 97, • .

ץ - استمارة استطلاع أراء السادة المحكمين لتحديد أبعاد "المفاهيم البيولوجية"، والأثكال

إعداد/ الباحثة ملحق (0)

\section{الأدبية المناسبة لطقل الروضة.}

قامت الباحثة بإعداد قائمة "بالمفاهيم البيولوجية "وقد تم تحديدها بعد الاطلاع على العديد من "المراجع والخلفيات النظرية " ثم إعداد الاستمارة في صـورتها النهائية، وتم عرضـها على السـادة الخبراء المحكمين، وقد تم تعديل الاستمارة في ضـوء آرائهم وقد اعتبرت الباحثة " المفاهيم البيولوجية" مناسبة إذا ما حصـلت على ( •^\%) فأكثر من الآراء واتفق السـادة الخبراء على سـتة من المفاهيم البيولوجية الأكثر مناسبة لطفل الروضة وهي: (الإنسان -النبات-الطيور -الحشرات-الكائنات البحرية والزواحف-السلسلة الغذائية).

ب-مقياس المفاهيم البيولوجية المصور لأطفال الروضة. إعداد/ الباحثة ملحق (7)

- الهرف من المقياس:

يهرف تصميم المقياس إلى قياس مدى اكتساب أطفال الروضة للمفاهيم البيولوجية ويتم القياس عن طريق عرض الباحثة لمواقف المقياس المصورة على الأطفال عن طريق إجراء المقابلة الفردية لكل طفل على حدة، وعرض المواقف المصورة مع توضيح العبارات المصاحبة لها من أجل مساعدة الطفل على اختيار البديل المصور الصحيح ويتكون المقياس من (بr) موقف مقسمين على الأبعاد التالية:

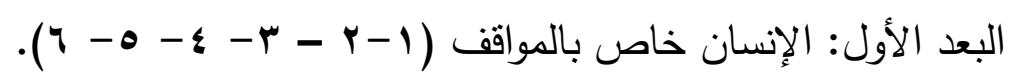

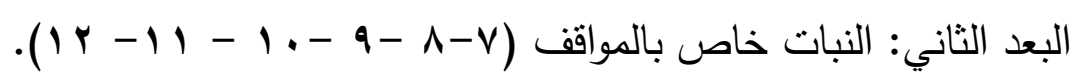

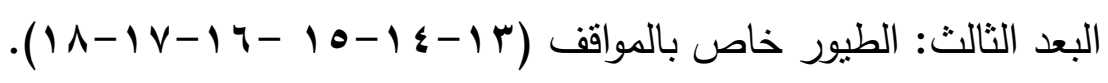

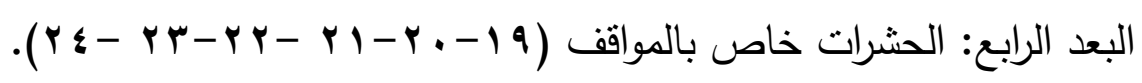

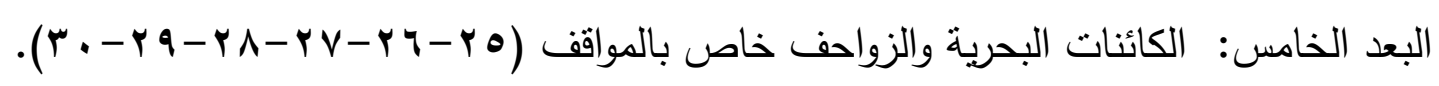

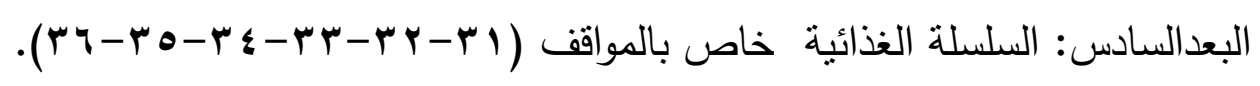
خطوات تصميم المقياس: - الاطلاع على البحوث والدراسـات الســابقة ذات الصــلة بموضـوع البحث للاســفادة منها في إعداد المقياس الحالي. - - تم وضــع التعريف الإجرائي للمفاهيم البيولوجية وتحديد أبعاده المتمثلة في (الإنسـان - النبات-الطيور -الحشرات- الكائنات البحرية والزواحف- السلسلة الغذائية) وكيفية قياسه إجرائًا. 
- قامت الباحثة بالاطلاع على عدد من المقاييس والاســنيانات التي ســـاهت بدورها في إعداد مقياس

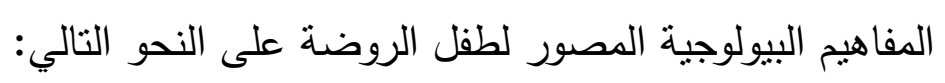

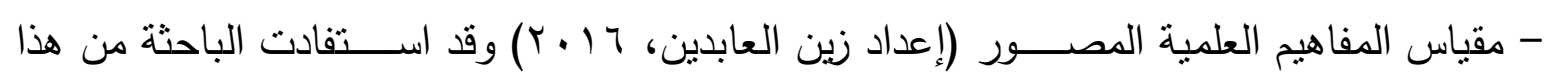

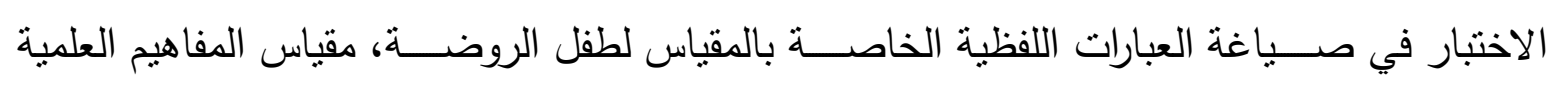

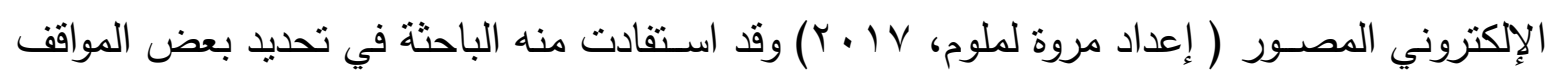

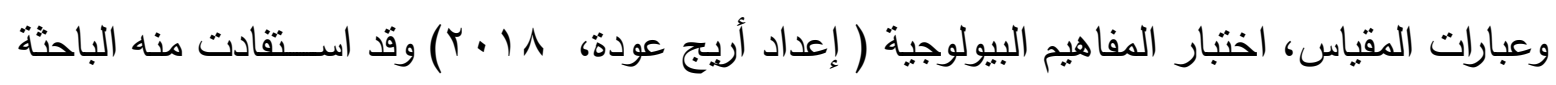
في تقـــيم ابعـاد المفـاهيم البيولوجيـة وبعض مفردات تلك الأبعاد، مقياس المفاهيم العلميـة لطفل

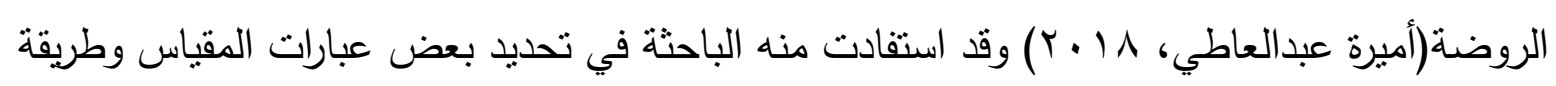

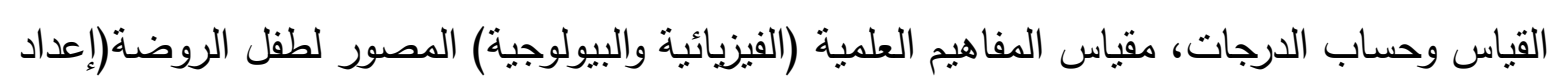

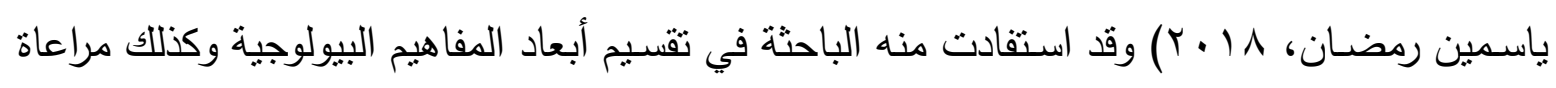

$$
\text { اتساق عبارات المقياس مع أبعاده. }
$$

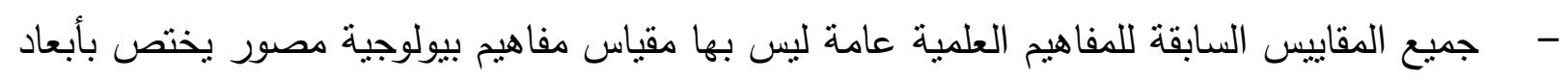
الكفاهيم البيولوجية فقط ولكنها تحنوي على بعض العبارات للمفاهيم البيولوجية، عدا مقياس أريج عودة.

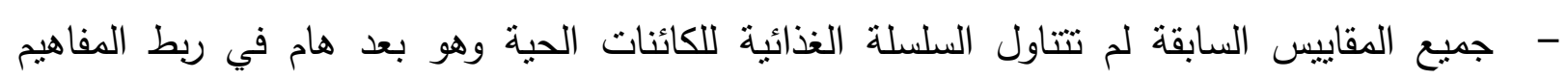
البيولوجية.

- - إعداد كل أبعاد المقياس حول المفاهيم البيولوجية، بحيث يكون مصور ليتتاسب مع طفل الروضة.

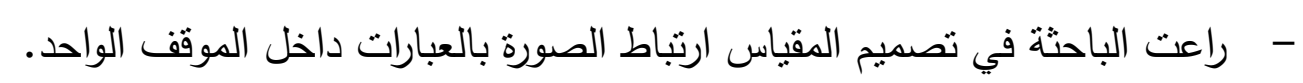
- - - راعت الباحثة في تصميم المقياس أن تكون بنوده مرتبطة بييئة الطفل.

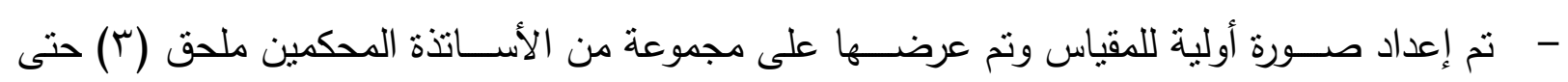
وصل إلى صورته النهائية ملحق (†). 
وتم تعديل مواقف المقياس من قبل الأساتذة المحكمين على النحو التالي:

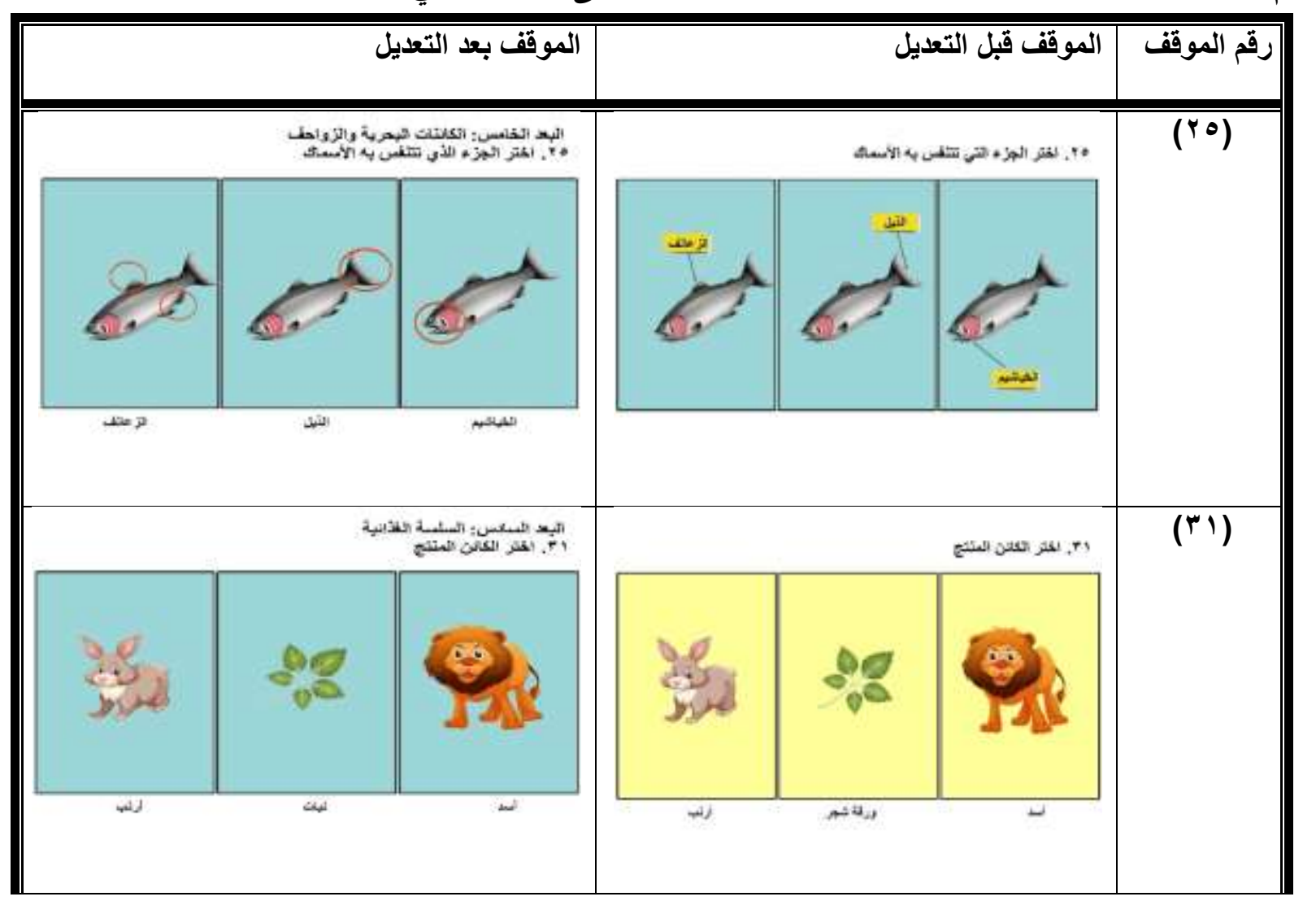

تعليمات المقياس:

- - تعرض الباحثة البطاقات المصسورة المكونة للمقياس على الطفل مع توجيه السؤال والاختيارات الخاصـة به بصوت واضح، ثم تطلب من الطفل اختيار الإجابة إما بالذكر أو بالإشارة على الصورة المعبرة عن بنه إجابته.

- زمن تطبيق المقياس: - قامت الباحثة بتحديد (•r دقيقة) لكل طفل، وذللك كمنوسـ للزمن الذي استتغرقه الأطفال في التجربة الاستطلاعية. طريقة تصحيح المقياس:

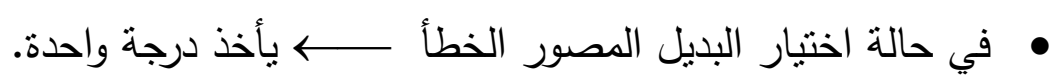

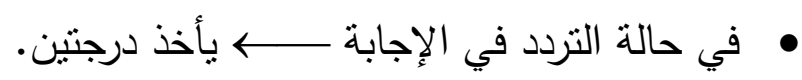

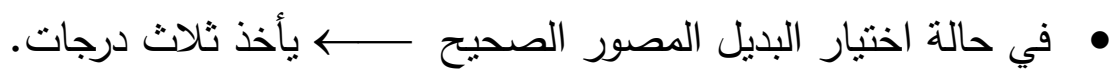
وتتدرج الدرجة الكلية للمقياس كحد أدنى (؟ب) درجة وكحد أعلى (1 • (1) درجة. 
الخصائص السيكومترية لمقياس المفاهيم البيولوجية المصور لأطفال الروضة أولاً: معاملات الصدق الصنق صدق المحكمين: قامت الباحثة بعرض المقياس على مجموعة من الســادة المحكمين المتخصــصــين في المجالات التربوية

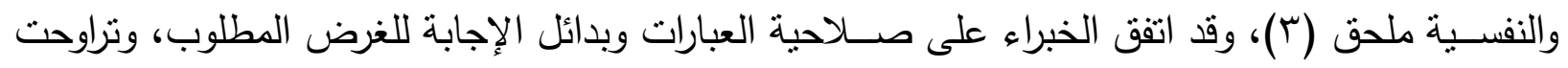

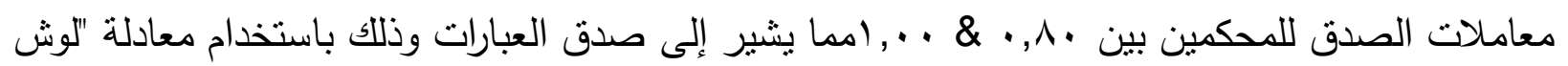
.Lawshe"

\section{جدول( 4}

يوضح معامل اتفاق السادة المحكين على مقياس المفاهيم البيولوجية المصور لطقل الروضة

\begin{tabular}{|c|c|c|}
\hline معامل الاتفاق & الأبعاد & م \\
\hline .69. & الإنسان & 1 \\
\hline 16. & النبات & $r$ \\
\hline 16. & الطيور & $r$ \\
\hline .69 & الحشرات & $\varepsilon$ \\
\hline$\cdot ، \wedge$. & الكائنات البحرية والزواحف & 0 \\
\hline $16 \ldots$ & السلسة الغذائية & 7 \\
\hline
\end{tabular}

الصدق العاملي:

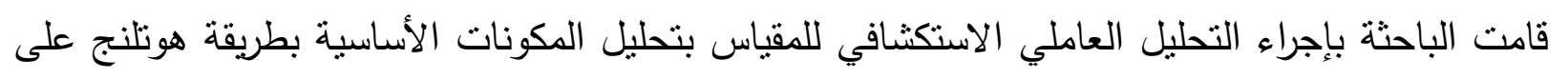

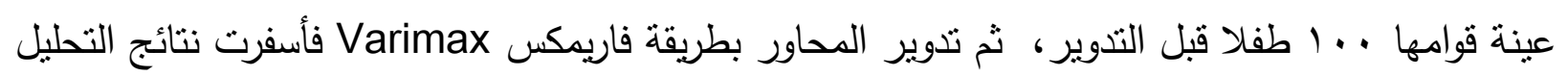

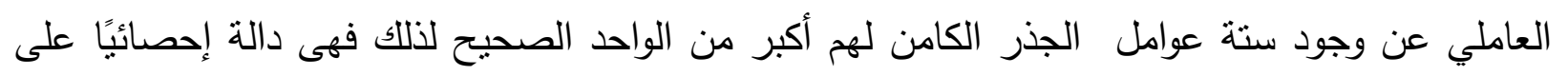

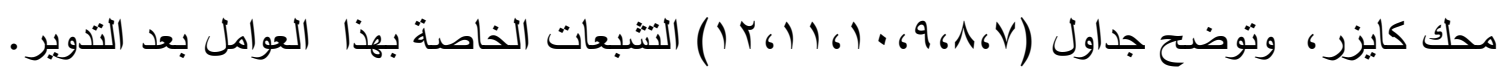
جاول (V) التثبعات الخاصة بالعامل الأول

الإنسان

\begin{tabular}{|c|c|c|}
\hline التشبعات & العبارة & العبارة \\
\hline$\cdot, 94$ & اختر الحاسة التي نستطيع من خلالها التمييز بين الحلو والمالح & 1 \\
\hline$\cdot, 9$. & اختر الحاسة التي تساعنا في التميز بين الناعم والخشن & $\bar{r}$ \\
\hline$\cdot, \wedge 0$ & ما العضو المسئول عن هضم الطعام؟ & $r$ \\
\hline$\cdot, \Delta r$ & اختر العضو المسئول عن التنفس في جسمنا & $\varepsilon$ \\
\hline$\cdot, \mathrm{V \mu}$ & ما الحاسة التي نحدد بها الرائحة السيئة ورائحة الأزهار؟ & 0 \\
\hline$\cdot, \mathrm{VT}$ & أين الكائن الغير حي في هذه الصورة؛ & 7 \\
\hline$\% 1 \leqslant, 94$ & نسبة التباين & \\
\hline $0, \mathrm{rV}$ & 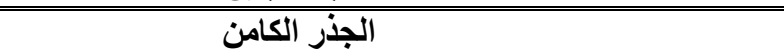 & \\
\hline
\end{tabular}

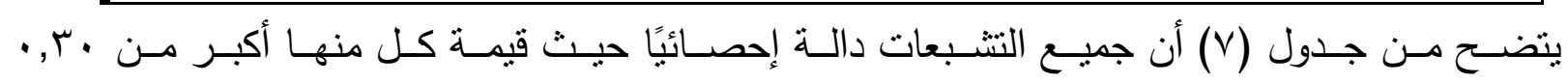
على محك جيلفورد. 


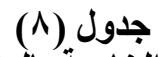

التثبعات الخاصة بالعامل الثانى

النبات التاصنات

\begin{tabular}{|c|c|c|}
\hline التشبعات & 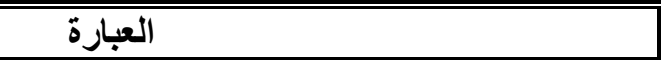 & رقم العبارة \\
\hline$\cdot, 9$. & أول جزء في النبات ينمو ويكون تحت التربة فما هو؟ & $\mathrm{V}$ \\
\hline$\cdot, \wedge 9$ & تحتاج البذور لتتبت وتنمو إلى & $\Lambda$ \\
\hline$\cdot, \wedge \mathrm{T}$ & جزء من النبات يقوم بحمل الأوراق فما هو؟ & 9 \\
\hline., 00 & أين تنمو ثمار البطاطس؟ & 1. \\
\hline$\cdot, \Sigma \mathrm{V}$ & ثمرة بذور ها من الخارج فما هي؟ & 11 \\
\hline$\cdot r$. & جزء من النبات يقوم بعملية البناء الضوئي فما هو؟ & Ir \\
\hline$\% 99,99$ & نسبة التباين & \\
\hline$r, 09$ & الجذر الكامن & \\
\hline
\end{tabular}

جدول (9) جلون

التشبعات الخاصة بالعامل الثالث

الطيور بالعام

\begin{tabular}{|c|c|c|}
\hline التشبعات & 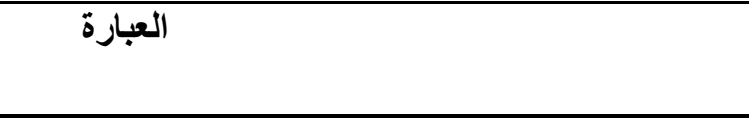 & رالعبارة \\
\hline$\cdot, \mathrm{V} \varepsilon$ & من الطيور التي لا تطير & 1T \\
\hline$\cdot, \mathrm{v} \cdot$ & من الطيور الجارحة & $1 \leqslant$ \\
\hline$\cdot, 7 \wedge$ & من الطيور التي يمكنها السباحة & 10 \\
\hline$\cdot, 0 \leqslant$ & من أكبر الطيور حجمًا وأسرعها في الجري & 17 \\
\hline$\cdot, 0$ & من الطيور المائية لها مجاديف تساعدها على السباحة & IV \\
\hline$\cdot, \pi r$ & يتميز بمنقار حاد وصلب وعينان ومخالب حادة فما هو؟ & 11 \\
\hline$\%$ & نسبة التباين & \\
\hline$r, v q$ & الجذر الكامن & \\
\hline
\end{tabular}

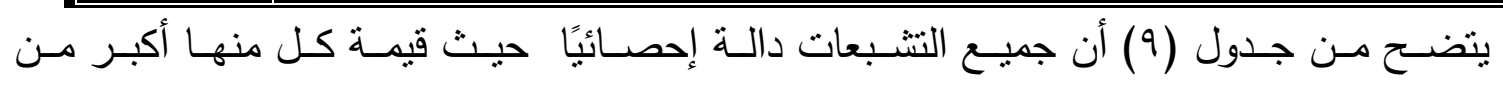

. ب, · على محك جيلفورد.

جدول (1) (1)

التشبعات الخاصة بالعامل الر ابع التمات

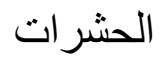

\begin{tabular}{|c|c|c|}
\hline التشبعات & 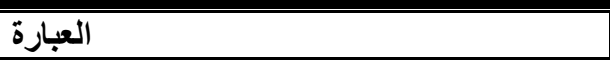 & رقم العبارة \\
\hline$\overline{., V T}$ & اختر الحشرة التي نأخذ منها العسل & 19 \\
\hline$\cdot, 71$ & اختر الحشرة الضارة & r. \\
\hline., 00 & اختر الحشرة التي تصنع خيوط الحرير & YI \\
\hline$\cdot$, . 1 & أين تعيش النحلة؟ & Tr \\
\hline$\cdot, 49$ & تتحول اليرقة إلى & rr \\
\hline.,$\leqslant 7$ & لايها ستة أرجل وقرنين استثعار فما هي؟ & Y \\
\hline$\% \vee \vee, \vee$ & نسبة التباين & \\
\hline$\overline{Y, 0 \leq}$ & الجذز الكامن & \\
\hline
\end{tabular}




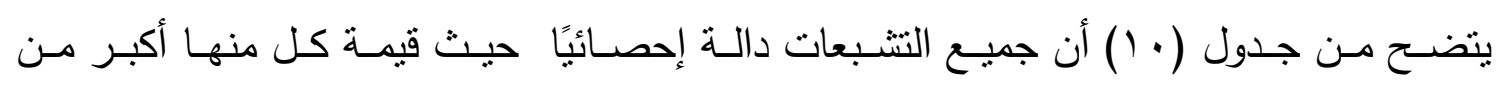

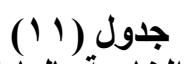

• اب, · على محك جيلفورد.

التثبعات الخاصة بالعامل الخامس

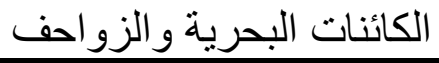

\begin{tabular}{|c|c|c|}
\hline التشبعات & 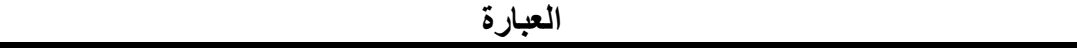 & 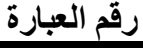 \\
\hline$\cdot, 71$ & اختر الجزء الأي تثنفس به الأسماك & ro \\
\hline$\cdot, 7 \varepsilon$ & اختر الجزء الأي يساعد السمكة على الحركة في الماء & r \\
\hline$\cdot, \mathrm{OV}$ & من الزواحف ويغطي جسمي قوقعة، ليس لي أسنان فمن أكون؟ & rV \\
\hline$\cdot, 00$ & كائن بحري من الثييات المائية له رئة ليتنفس ويلد، فما هو؟ & rᄉ \\
\hline$\cdot$, ro & من الزواحف ولايه أسنـان قوية ويغطي جسمه حر اشف ويعيش في البر والماء، فما هو؟ & rq \\
\hline . & كائن بحري لايه ثمان أزرع وثلاث قلوب ويفرز سحابة سوداء من الحبر، فما هو؟ & r. \\
\hline$\%$ & نسبة التباين & \\
\hline$r, r \varepsilon$ & 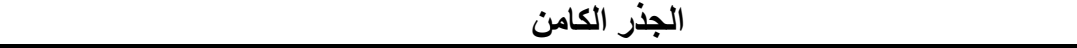 & \\
\hline
\end{tabular}

يتضــح مـن جـدول (1) أن جميـع التشـبعات دالـة إحصـائيًا حــث قيمـة كـل منهـا أكبـر مـن

• اب, · على محك جيلفورد.

جدول (r)

التشبعات الخاصة بالعامل السادس (1) الغاسلة

السلسلة الغذائية

\begin{tabular}{|c|c|c|}
\hline التشبعات & العبارة & رقم العبارة \\
\hline$\cdot, \mathrm{N}$ & اختر الكائن المنتج & rI \\
\hline$\cdot, 7 \varepsilon$ & اختر الكائن المستهلك & rr \\
\hline$\cdot, \varepsilon \mathrm{V}$ & تبدأ السلسلة الغذائية بكائن منتج ذاتي التغذية، فما هو؟ & $r \mu$ \\
\hline$\cdot, \Sigma$. & اختر الحيوان آكل اللحم & $\Gamma \leq$ \\
\hline$\cdot$ & اختر الكائن الحي الذي يتغذى على النباتات & ro \\
\hline e,r & اختر الصورة التي تكون السلسلة الغذائية & $r 7$ \\
\hline$\% 0, \wedge 4$ & نسبة التباين & \\
\hline$r, 11 r$ & الجذر الكامن & \\
\hline
\end{tabular}

يتضـح مـن جدول (Y I ) أن جميـع النشـبعات دالـة إحصـائيًا حبـث قيمـة كل منهـا أكبر مـن

• ب, · • على محك جيلفورد.

ثانياً: معاملات الثبات لمقياس المفاهيم البيولوجية

قامــت الباحثـة بايجـاد معـاملات الثبـات بطريقتهي الفـا كرونبـاخ وإعـادة التطبيـق على عينـة قوامهـا

. . . .

ا-بطريقة القا كرونباخ

قامت الباحثة بإيجاد معامالات الثبات لمقياس المفاهيم البيولوجية بطريقة الفا كروذباخ كما يتضـــح في

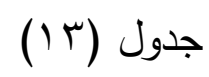




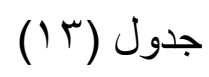

معاملات الثبات لمقياس المفاهيم البيولوجية

بطريقة الفا كرونباخ الغياخ

\begin{tabular}{|c|c|}
\hline معاملات الثبات & الأبعاد \\
\hline$\overline{\cdot, \mathrm{V})}$ & الإنسان \\
\hline$\cdot, \mathrm{v}$. & 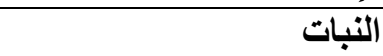 \\
\hline$\cdot, \mathrm{Vq}$ & 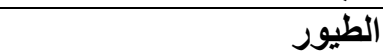 \\
\hline$\cdot, \mathrm{VT}$ & 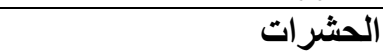 \\
\hline$\cdot, \times 4$ & الكائنات البحرية والزواحف \\
\hline$\cdot, \mathrm{V} \wedge$ & السلسلة الغذائية \\
\hline$\cdot, V Y$ & الارجة الكلية \\
\hline
\end{tabular}

يتضح من جدول (r ا ) أن قيم معاملات الثبات مرتفعة مما يذل على ثبات المقياس.

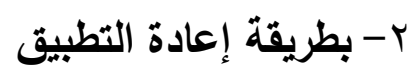

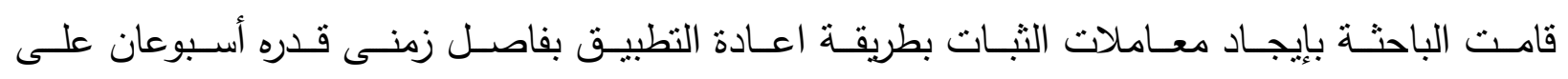

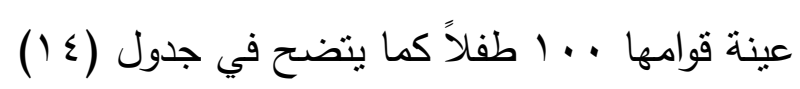

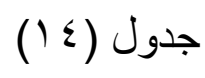

معاملات الثبات لمقياس المفاهيم البيولوجية (1) إعلية

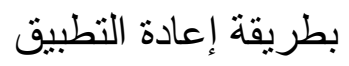

\begin{tabular}{|c|c|}
\hline معاملات الثبات & الأبعاد \\
\hline$\overline{., 91}$ & الإنسان \\
\hline$\cdot, 9$ & 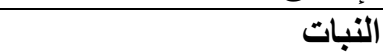 \\
\hline., 94 & الطيور \\
\hline$\cdot, 9 Y$ & الحشر ات - ات \\
\hline$\cdot, 91$ & الكائنات البحرية والزواحف \\
\hline$\cdot, 9 \leqslant$ & السلسلة الغذائية \\
\hline 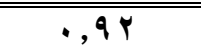 & الارجة الكلية \\
\hline
\end{tabular}

يتضح من جدول (ع ا ) أن قيم معاملات الثبات مرتقعة مما يدل على ثبات المقياس. وفيما يلي عرض لإحدى مواقف المقياس: لئحرن 


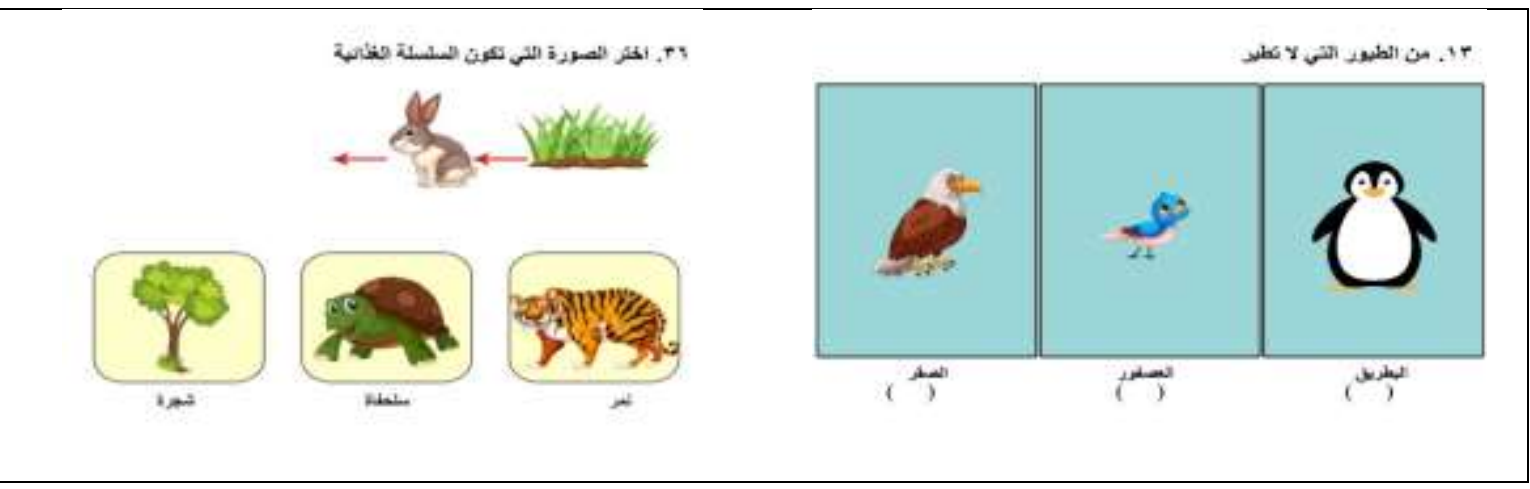

ع - بطاقة ملاحظة سلوكيات الأطفال حول المفاهيم البيولوجية إعداد/ الباحثة ملحق (v)

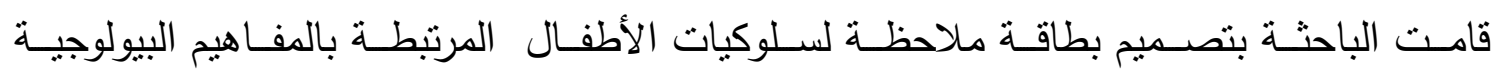

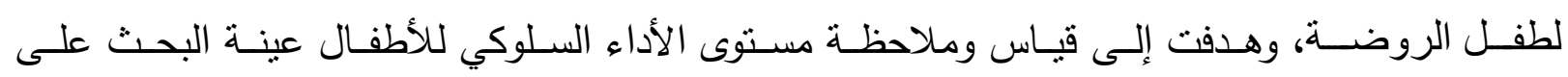
أبعاد المفاهيم البيولوجية. خطوات تصميم بطاقة الملاحظة: - - تحديد أهداف استمارة الملاحظة. - تحديد السلوكيات المر اد قياسها وتحديدها في عبار ات بالبطاقة وصياغتها.

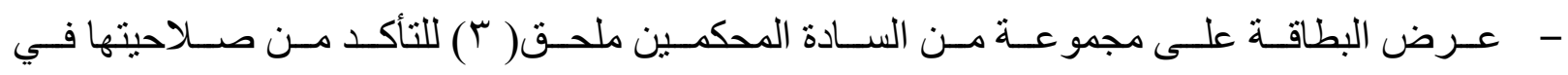
ملاحظة سلوكيات الأطفال . - - مساب المعاملات العلمية لبطاقة الملاحظة. وبناء على ذلك قامت الباحثة بالآتي: تقيم سلوك الأطفال المرتبط "بالمفاهيم البيولوجية" قبل تطبيق أنتطة البرنامج.

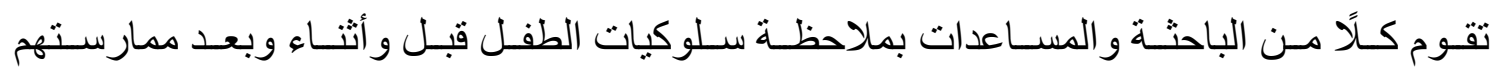

$$
\text { لأنشطة البرنامج. }
$$

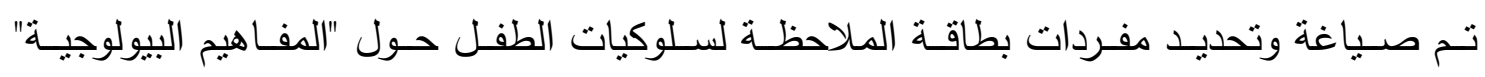
وقد تكونت بطاقة الملاحظة من (•r مفردة) مقسمة على ستة أبعاد:

$$
\begin{aligned}
& \text { البعد الأول: الإنسان (1-0) } \\
& \text { البعد الثاني :النبات(الإن- الإندان (1) } \\
& \text { البعد الثالث : الطيور (1) :10 (1) }
\end{aligned}
$$

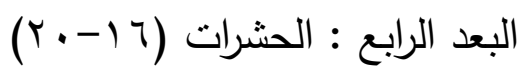

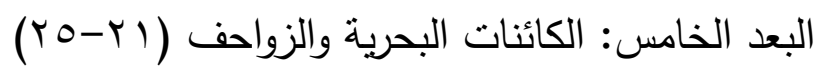

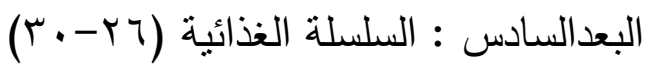


- وقد راعت الباحثة وضوح العبارات ودقتها في وصف السلوك المراد ملاحظته.

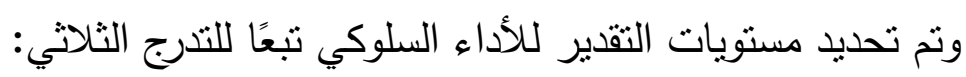
دائما = r درجات، أحيانًا = درجتان، نادرًا = درجة واحدة.

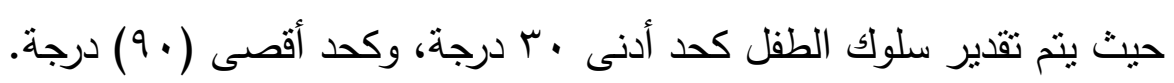

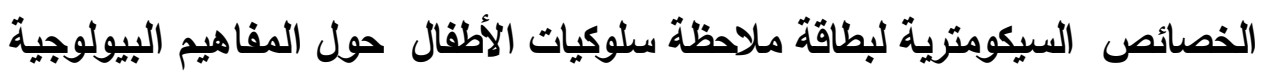

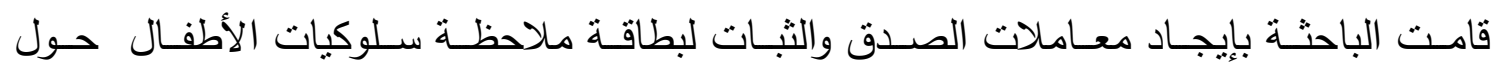

المفاهيم البيولوجية وذلك على عينة قوامها ـ . . 1 طفلًا.

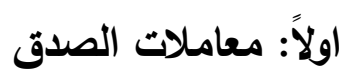

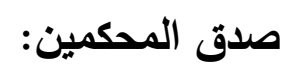

قامت الباحثة بحساب صدق المحكمين " لبطاقة ملاحظة سلوكيات الأطفال حول المفاهيم البيولوجية " وإيجاد

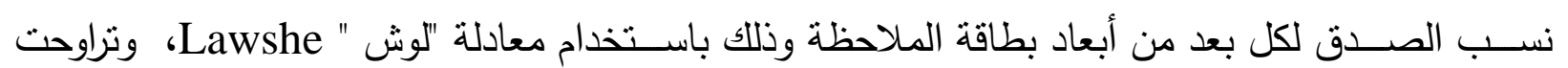

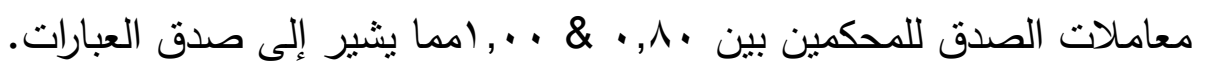

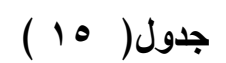

يوضح معامل اتفاق السادة المحكمين على أبعاد بطاقة ملاحظة سلوكيات الأطفال المرتبطة بالمفاهيم البيولوجية

\begin{tabular}{|c|c|c|}
\hline معامل الآفاق & أبعاد بطاقة الملاحظة & $\overline{5}$ \\
\hline .69. & الإنسان & 1 \\
\hline $1, \ldots$ & النبات & $r$ \\
\hline .99. & الطيور & $r$ \\
\hline$\cdot$ •`^. & الحشرات & $\varepsilon$ \\
\hline .199 & الكائنات البحرية و الزواحف & 0 \\
\hline $1, \ldots$ & السلسلة الغذائية & 4 \\
\hline
\end{tabular}

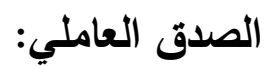

قامت الباحثة باجراء التحليل العاملي الاستكثافى للبطاقة بتحليل المكونات الأساسية بطريقة هوتلنج

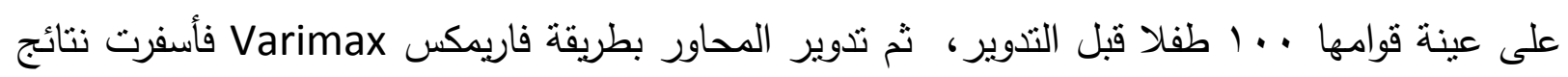
التحليل العاملي عن وجود ستة عوامل الجذر الكامن لهم أكبر من الواحد الصحيح لذللك فهى دالة إحصائيًا

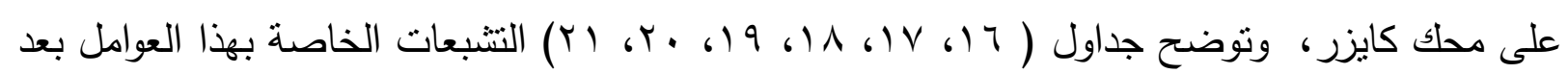

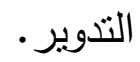


جدول (17 )

التثبعات الخاصة بالعامل الأول

الإنسان

\begin{tabular}{|c|c|c|}
\hline التشبعات & العبارة & العبارة \\
\hline., $9 \varepsilon$ & يربط بين الحواس وأعضائها في جسم الإنسان & $\bar{T}$ \\
\hline., 94 & يذكر أهمية الرئتين للانسان & $r$ \\
\hline$\cdot, 94$ & يحدد الجهاز المسئول عن الهضم & $\mu$ \\
\hline., 94 & يميز بين عمليتين الثهيق والزفير & $\varepsilon$ \\
\hline$\cdot, 94$ & يذكر خصائص الكائن الحي & 0 \\
\hline $\begin{array}{c}r \wedge,\{r \\
\%\end{array}$ & نسبة التباين & \\
\hline 11,04 & الجذر الكامن & \\
\hline
\end{tabular}

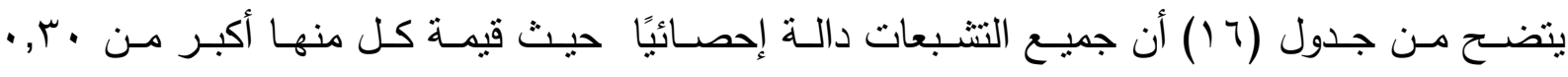

جدول (IV)

على محك جيلفورد.

التثبعات الخاصةُ بالعامل الثاني

النبات الثاهة

\begin{tabular}{|c|c|c|}
\hline التشبعات & 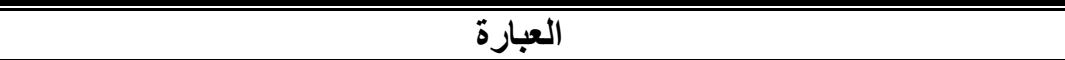 & رقم العبارة \\
\hline$\cdot, 97$ & ئذكر ما تحتاجة البذور للإنبات & 7 \\
\hline$\cdot, 97$ & يأكر مكونات أجزاء النبات & $\mathrm{V}$ \\
\hline$\cdot, 94$ & يحدد أهمية ووظيفة أجزاء النبات & $\Lambda$ \\
\hline$\cdot, 94$ & يميز بين بعض النباتات التي تنمو ثمارها تحت الارض أو فوق الارض & 9 \\
\hline$\cdot, \wedge \mathrm{T}$ & يحدد مكان تواجد البذور لبعض النباتات(داخل الثمرة-خارج الثمرة-داخل قرون) & 1. \\
\hline $\begin{array}{c}17,04 \\
\%\end{array}$ & نسبة التباين & \\
\hline$\varepsilon, 97$ & الجذر الكامن & \\
\hline
\end{tabular}

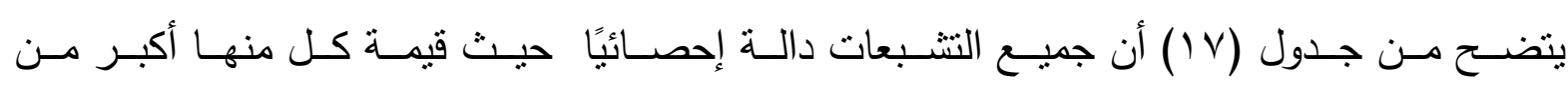

جدول (1) جاهعل

• ب, · على محك جيلفورد.

التشبعات الخاصةُ بالعامل الثالث

الطيور بالعامر

\begin{tabular}{|c|c|c|}
\hline التشبعات & 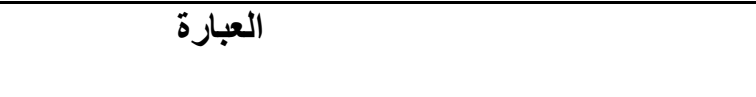 & رقلعارة \\
\hline$\cdot, 9 \vee$ & يحدد الطيور التي لاتطير & 11 \\
\hline$\cdot, 94$ & يذكر السمات المميزة للطيور.(لها ريش.أجنحة وتبيض) & Ir \\
\hline$\cdot, 7 \varepsilon$ & يحدد الطيور الجارحة & ir \\
\hline$\cdot, \leqslant \wedge$ & يأكر طعام كل طائر & $1 \leqslant$ \\
\hline$\cdot, \varepsilon r$ & يميز الطيور المائية & 10 \\
\hline$\% \wedge, \vee \vee$ & نسبة التباين & \\
\hline r, & الجذر الكامن & \\
\hline
\end{tabular}




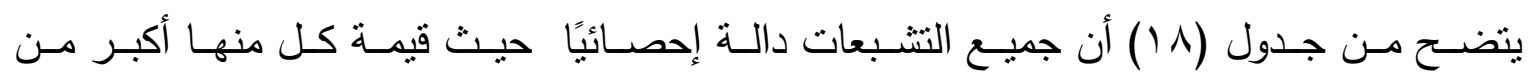

جدول (19 (1)

• ا., · على محك جيلفورد.

التشبعات الخاصةٌ بالعامل الرابع

الحشر ات باتعامل

\begin{tabular}{|c|c|c|}
\hline التشبعات & العبارة & رقم العبارة \\
\hline$\overline{e, \mathrm{~V}_{0}}$ & يذكر أجزاء جسم الحشرة & 17 \\
\hline$\cdot, \mathrm{v}$. & يذكر دورة حياة بعض الحشرات & IV \\
\hline$\cdot$, TV & يميز بعض الحثرات النافعة & 11 \\
\hline., $0 \mathrm{~V}$ & يذكر بعض الحشر ات الضارة & 19 \\
\hline$\cdot, r$. & يذكر منتجات بعض الحشرات النافعة & $r$ r. \\
\hline$\% \%^{0, Y^{4}}$ & نسبة التباين & \\
\hline 1,01 & الجذر الكامن & \\
\hline
\end{tabular}

يتضـح مـن جدول (9 ( ) أن جميـع النشـبعات دالـة إحصـائيًا حيـث قيمـة كل منهـا أكبر مـن

• اب, · على محك جيلفورد.

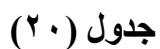

التثبعات الخاصة بالعامل الخامس

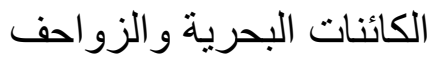

\begin{tabular}{|c|c|c|}
\hline التثبعات & 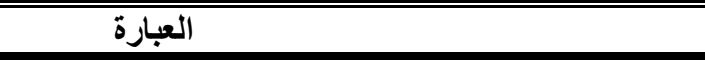 & رقم العبارة \\
\hline$\cdot, \wedge \varepsilon$ & يحدد الجزءالمسئول عن التففس في الأسماك & YI \\
\hline$\cdot, \mathrm{VO}$ & ئكر أجزاء جسم السمكة & rY \\
\hline$\cdot, \mathrm{TV}$ & يذكر خصائص الثذييات البحرية & $r r$ \\
\hline., $\mathrm{OV}$ & يذكر الخصائص المميزة للأخطبوط & $r \leq$ \\
\hline$\cdot, r$. & يأكر خصائص بعض الزواحف( التمساح والسلحفاه) & ro \\
\hline$\% \leqslant, \leqslant 9$ & نسبة التباين & \\
\hline $1, r \varepsilon$ & الجذر الكامن & \\
\hline
\end{tabular}

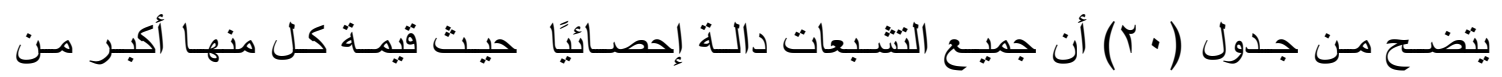

• آ, · على محك جيلفورد.

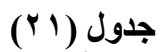

التثبعات الخاصة بالعامل السادس

السلسلة الغذائية

\begin{tabular}{|c|c|c|}
\hline التشبعات & 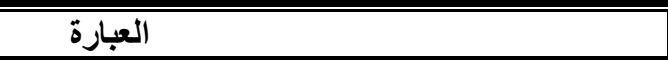 & رقم العبارة \\
\hline 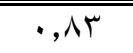 & يحدد الكائن المنتج في السلسة الغذائية & $\overline{r q}$ \\
\hline$\cdot, \mathrm{V} \leqslant$ & يحدد الكائن المستهلك في السلسة الغذائية & $r V$ \\
\hline ז4, & يذكر بداية السلسة الغذائية & rᄉ \\
\hline$\cdot, 0 \mathrm{~V}$ & يكون سلسة غذائية & rq \\
\hline$\cdot, \mu 4$ & يميز بين الكائنات الحية آكلة اللحوم وآكلة النبات & $r \cdot$ \\
\hline$\% \leqslant,+1$ & نسبة التباين & \\
\hline $1, r$ & الجذر الكامن & \\
\hline
\end{tabular}

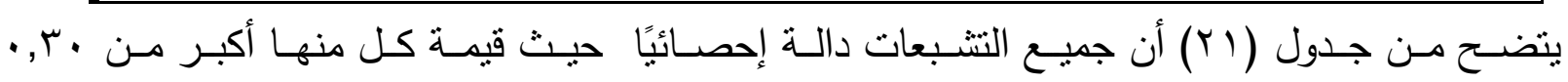
على محك جيلفورد. 
ثانياً: معاملات الثبات لبطاقة ملاحظة سلوكيات الأطفال حول المفاهيم البيولوجية

قامـت الباحثـة بإيجـاد معـاملات الثبـات بطريقتى الفـا كرونبـاخ واعـادة التطبيـق على عينـة قوامهـا

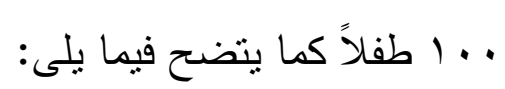

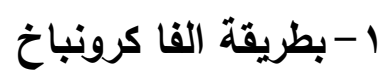

قامت الباحثة بإيجاد معاملات الثبات لبطاقة ملاحظة سلوكيات الأطفال حول الدفاهيم البيولوجية بطريقة

$$
\text { الفا كرونباخ كما يتضح في جدول (Yr) }
$$

جدول (rr)

معاملات الثبات لبطاقة ملاحظة سلوكيات الأطفال حول المفاهيم البيولوجية بطريقة الفا كرونباخ

\begin{tabular}{|c|c|}
\hline معاملات الثبات & الأبعاد \\
\hline$\cdot, \mathrm{VY}$ & الإنسان \\
\hline$\cdot, \wedge$. & 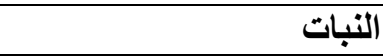 \\
\hline$\cdot, \mathrm{v} 0$ & 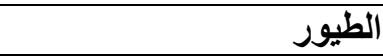 \\
\hline$\cdot, \mathrm{V})$ & الحشرات \\
\hline$\cdot, \mathrm{Vq}$ & الكائنات البحرية والزواحف \\
\hline$\cdot, \mathrm{VT}$ & السلسلة الغذائية \\
\hline$\overline{\theta, \Lambda Y}$ & الارجة الكلية \\
\hline
\end{tabular}

يتضح من جدول (rr) أن قيم معاملات الثبات مرتفعة مما يذل على ثبات المقياس.

r- بطريقة إعادة التطبيق

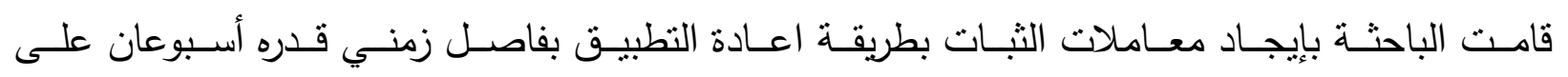

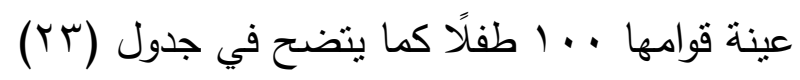
جدول (rr)

معاملات الثبات لبطاقة ملاحظة سلوكيات الأطفال حول المفاهيم البيولوجية بطريقة إعادة النطبيق

\begin{tabular}{|c|c|}
\hline معاملات الثبات & الأبعاد \\
\hline., $9 \leqslant$ & الإنسان \\
\hline$\cdot, 9 Y$ & 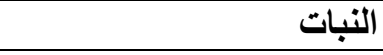 \\
\hline., 90 & الطيور \\
\hline$\cdot, 94$ & الحشرات \\
\hline$\cdot, 9 \leqslant$ & الكاننات البحرية و الزواحف \\
\hline$\cdot, 9 Y$ & السلسلة الغذائية \\
\hline., 94 & الارجة الكلية \\
\hline
\end{tabular}


يتضح من جدول (Tr) أن قيم معاملات الثبات مرتفعة مما يدل على ثبات المقياس.

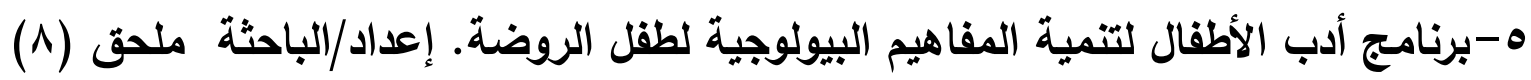

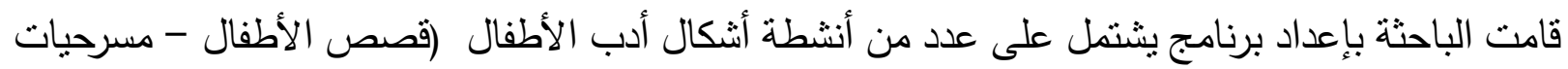

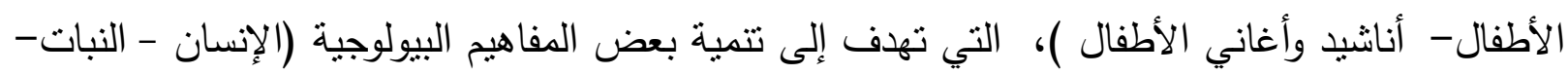

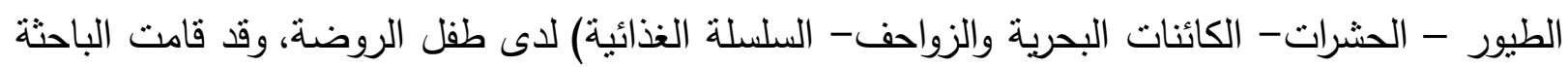

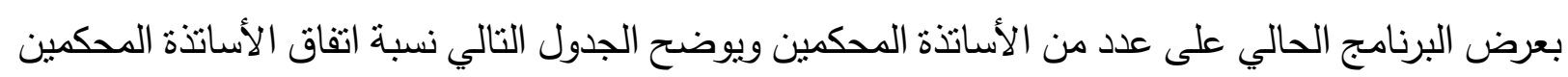
على وحدات البرنامج.

جدول (Y)

يوضح معامل اتفاق الأساتذة المحكمين على وحدات برنامج أدب الأطفال

\begin{tabular}{|c|c|}
\hline معامل الاتفاق & مكونات البرنامج \\
\hline$\% 9$. & | ل الإنسان \\
\hline$\% 1 \ldots$ & النبات \\
\hline$\%^{\wedge}$. & الطيور \\
\hline$\% 1 \ldots$ & | ل الحشرات \\
\hline$\% 9$. & الكائنات البحرية و الزواحف \\
\hline$\% 9$. & السلسلة الغذائية \\
\hline
\end{tabular}

الهرف العام للبرنامج:

تتمية بعض المفاهيم البيولوجية لدى طفل الروضة من خلال برنامج قائم على أنشطة أدب الأطفال.

الأهداف الإجرائية للبرنامج:

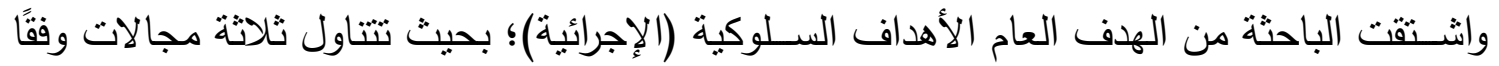

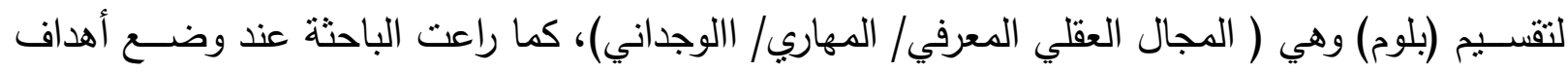

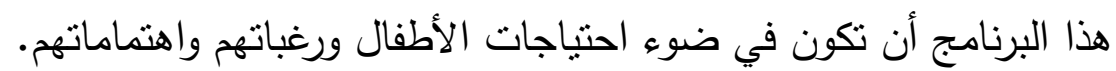

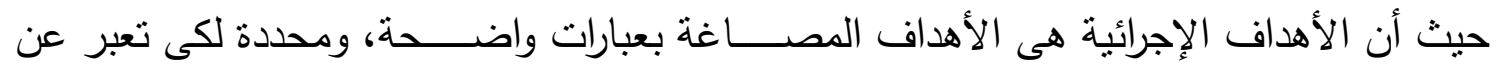
السلوك الذي يقوم به الطفل ولابد أن تتوافر بها الأه مجموعة من الثراف الثروط وهى :

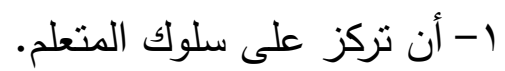

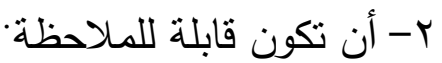

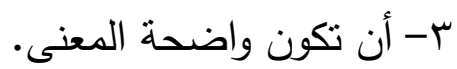

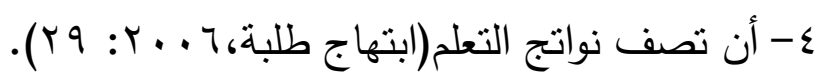
حيث يهدف برنامج أنشـطة أدب الأطفال لتتمية الدفاهيم البيولوجية إلى تحقيق الأهداف السـلوكية

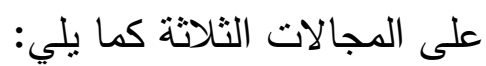




\section{أولاً: الأهداف السلوكية في المجال العقلي المعرفي:}

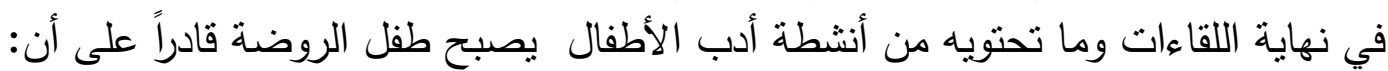

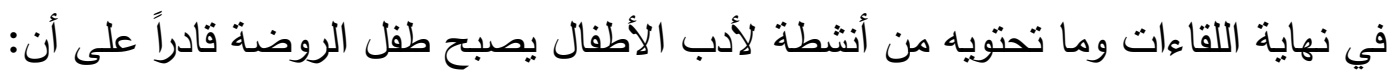
ا ـ. يذكر وظيفة كل حاسة من الحواس الخمسة r. بميز بين وظيفة كل جهاز من أجهزة الجسم.

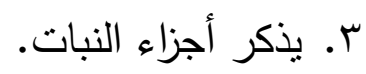
ع. يرتب أجزاء النبات بتسلسلها المنطقي. ه. يذكر اسم الحشرات الواردة بالمسرحية.

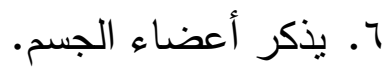
V. يصل بين الكائن الحي ومنتجه. ^. بربط بين الطائر وغذائه.

9. يرتب السلسلة الغذائية بطريقة صحيحة.

ثانياً: الأهداف السلوكية في المجال المهاري (النفسحركي):

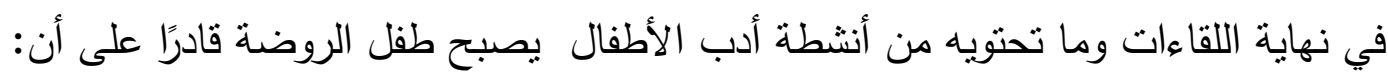
ا ـ يؤدي المهام التي تطلبها منه الباحثة. r r r بحكي القصة بمفرده. r. بل بلون الصورة المعروضة أمامه. ـ. يغني كلمات الأغنية بطريقة صحيحة. ه. يؤدي المهام التي تطلبها منه الباحثة. 7. بحكي القصة بمفرده. V. يقلد حركات الباحثة مع الأغنية. ^. يشارك أصدقائه في تمثيل المسرحية. ثالثاً: الأهداف السلوكية في المجال الوجداني (الاجتماعي والانفعالي):

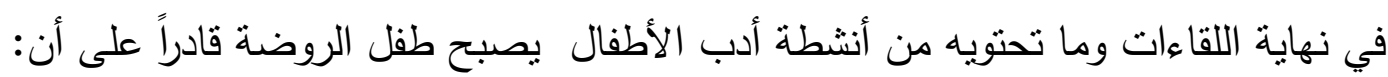

$$
\text { 1. 1. بصغي لشرح الباحثة باهنمام. }
$$

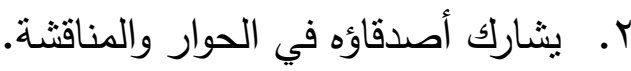
r. بـتمتع مع زملائه في العمل التعاوني. ع. يبدي الطفل إعجابه بأنواع الآلات الموسيقية المختلفة. ه. يشارك زملاءه في الغناء. T. بتعاون مع أصحابه في تثنثل أحداث القصة. أسس بناء البرنامج: عند تصميم البرنامج قامت الباحثة بوضع مجموعة من الأسس وهي: 
- - أن يكون المحتوى مرتبط بالهدف الذي صمم من أجله البرنامج.

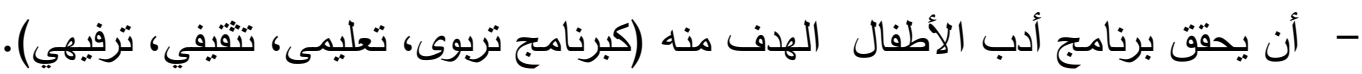

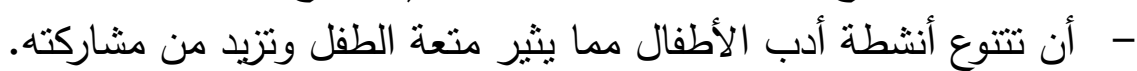

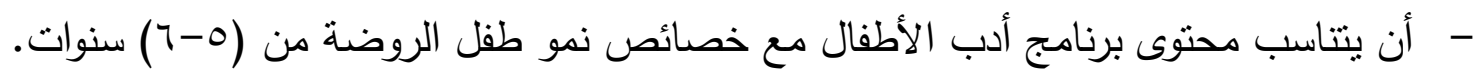

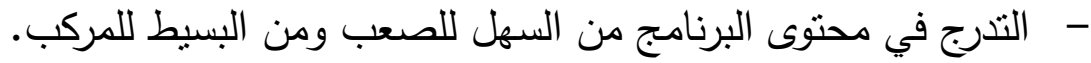

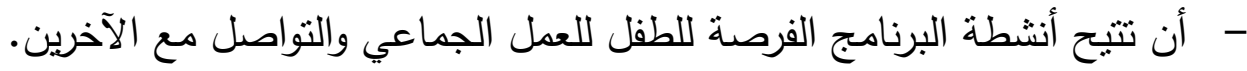

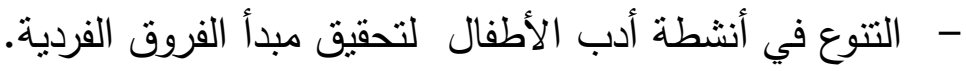

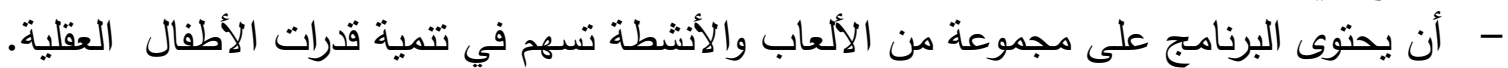

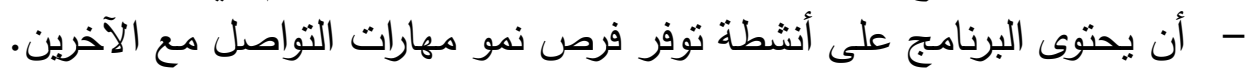
- - استخدام مبدأ التعزيز لتتجيع الأطفال على أداء الأنشطة. - - مراعاة طرق الثقويم المناسبة للنشاط.

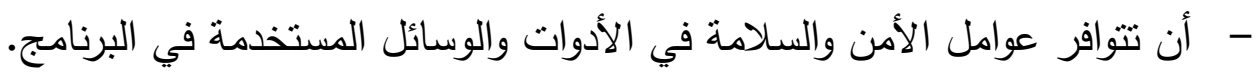

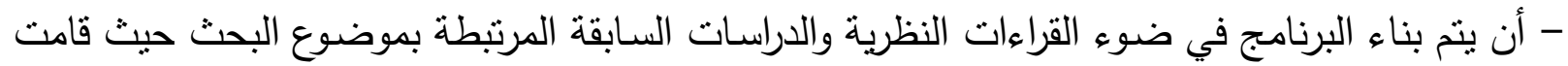

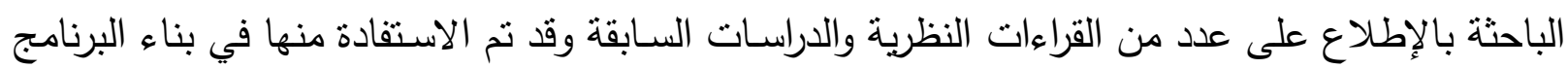

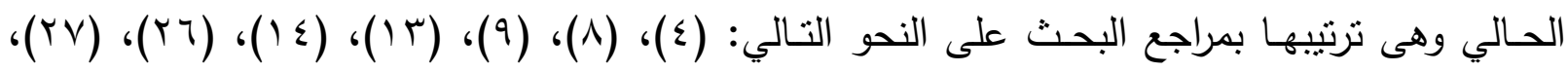

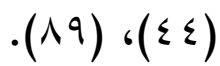

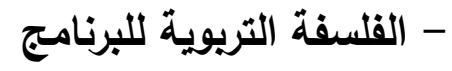

تتبثق الفلسفة التربوية للبرنامج الحالي من فلسفة المجتمع الذي يعيش فيه الطفل من ضرورة وحتمية تتمية المفاهيم البيولوجية لما لها من أثز إيجابي في تحقيق النمو الثنامل والتقافة العلمية؛ بمعرفة الكائنات

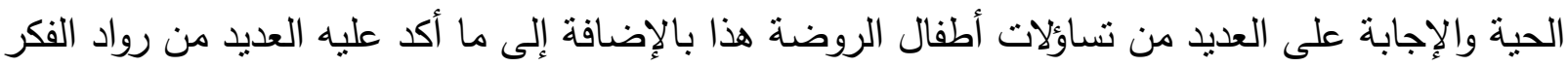

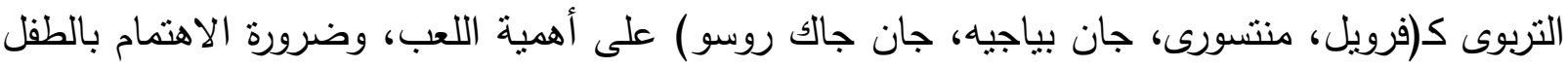

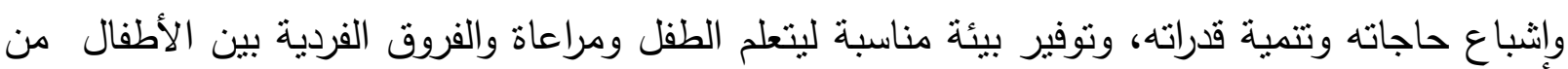
خلال تقديم الأنشطة المنتوعة. وقد أكدت "ماريا منتسوري" على أهمية اللعب كمذل رئيسي للتعليم وهذا ما يتتاسب بدرجة كبيرة مع أطفال

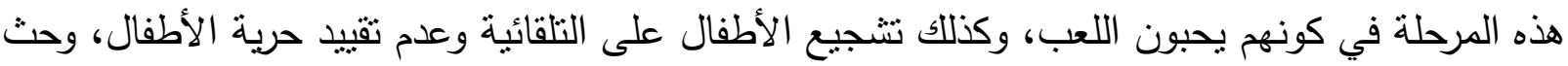

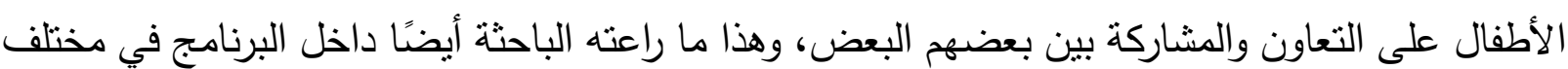

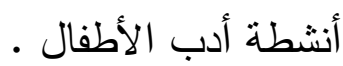
وقد تبنت الباحثة (نظرية التعلم الاجتماعي) لباندورا (Bandora) وتعتمد هذه النظرية على تعلم

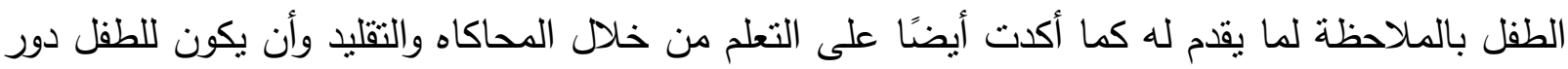

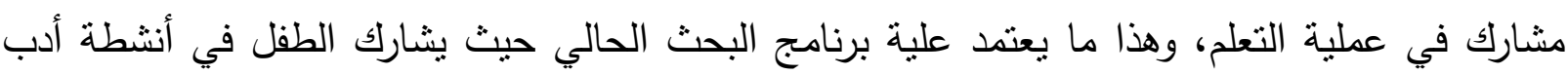
الأطفال التى تتنوع بين(قصص الأطفال - مسرحيات الأطفال-أغاني وأنانيد الأطفال). 
وقد أكد "ثورنديك" خلال نظريته على التعلم بالمحاولة والخطأ، أن الموقف التعليمي يكون ناجحًا

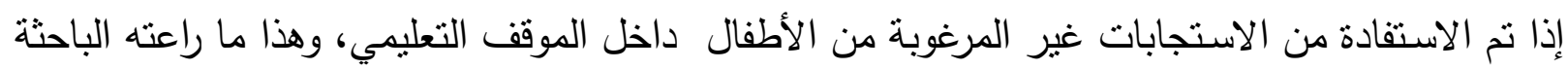

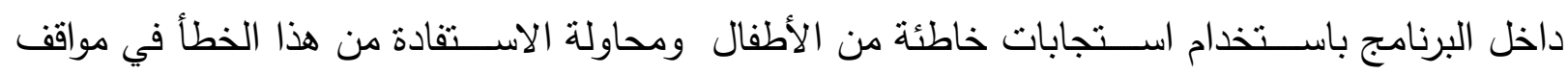
تعليمية مختلفة داخل أنشطة البرنامج.

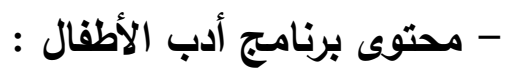

يتكون برنامج أدب الأطفال من (جب) لقاء، وكل لقاء يحتوي على نثـاط من أنشـة أدب الأطفال يعقب كل نثـاط تطبيقات تربوية وقد روعي في تقديمها الفروق الفردية، ومراعاة التبسيط والإثارة والنتشويق، وينقسم البرنامج الحالي إلى ستة وحدات رئيسية: الوحدة الأولى: وتتضمن مفهوم الإنسان.

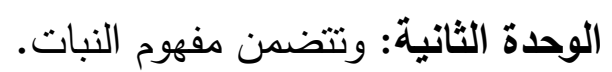

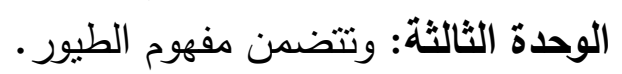
الوحدة الرابعة: وتتضمن مفهوم الحشرات.

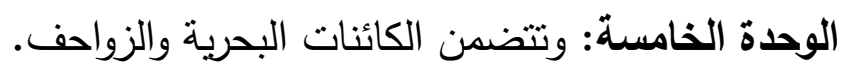

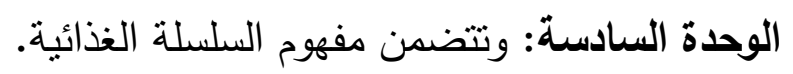

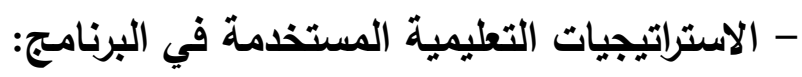

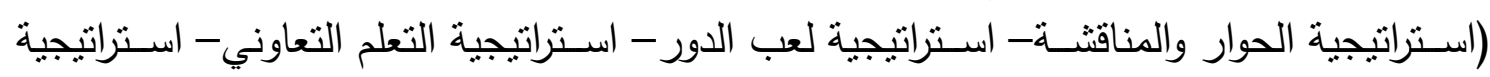

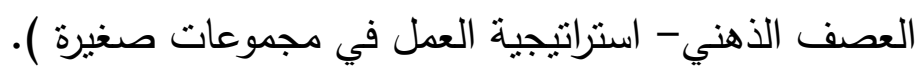
- الأدوات والوسبائل المستخدمة في البرنامج: قصـص ألبوم - مسـرح عرائس - عرائس منتوعة- آلات موسيقية إئية إيقاعية- بطاقات مصـورة- أقلام

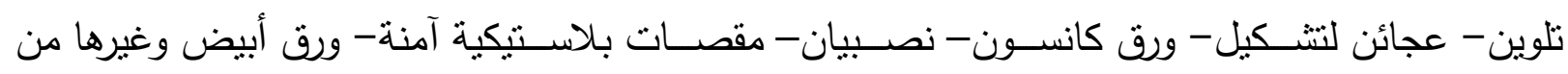

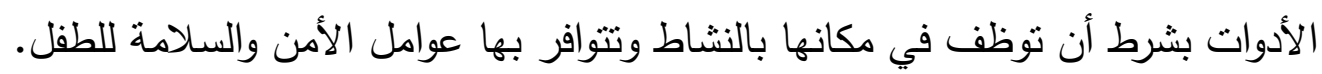

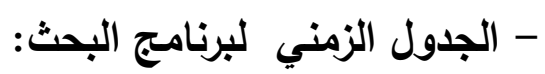

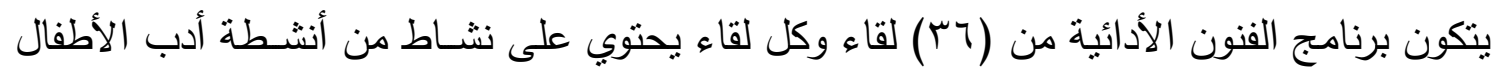

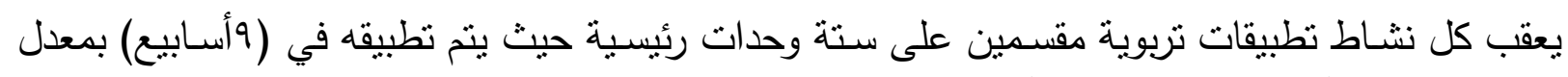

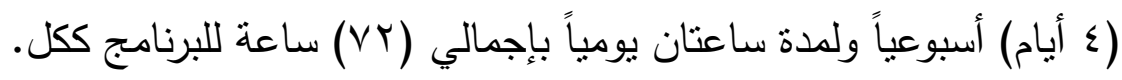

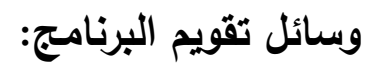
تتوعت وسـائل التقويم المســتخدمة للحكم على مدى نجاح البرنامج وتحديد جوانب القصــور التي تتطلب تحسين أو تعديل على النحو التالي:

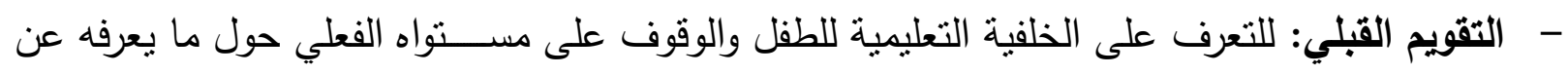

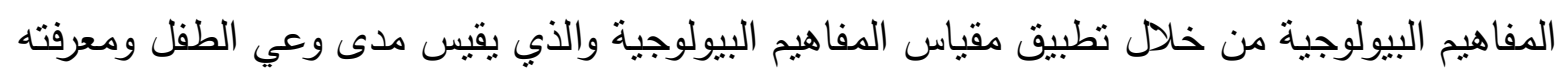
بتلك المفاهيم. - التقويم المرحلي: وهو تقويم مصــــاحب من بداية البرنامج وحتى نهايته ويتم هذا النوع من التقويم من 
- ملاحظة سلوك الأطفال اليومى أثناء تأدية الأنشطة بهدف التعرف على مدى تجاوب الأطفال للخبرات

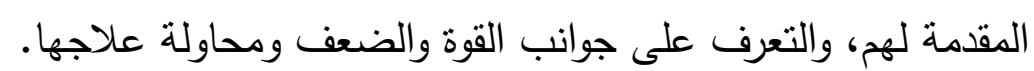

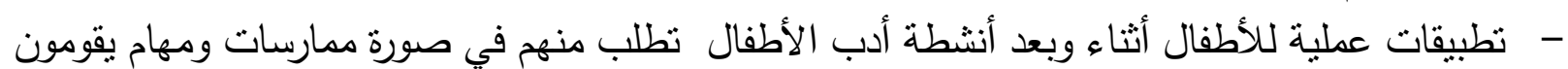
بأدائها في صورة فردية وجماعية.

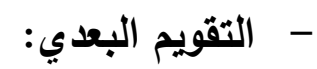
ويكون من خلال إعادة تطبيق مقياس الدفاهيم البيولوجية وبطاقة الملاحظة الذي تم تطبيقهما قبل

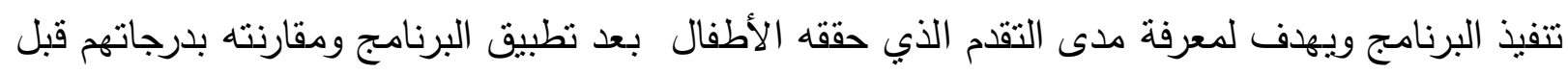
التطبيق. وفيما يلي عرض لإحدى أنثطة أدب الأطفال للبرنامج: اسم النثاط: مسرحية الحواس الخمسة نوع النشاط: مسرحي

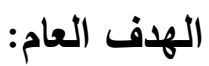

تتمية معرفة الطفل بأهمية الحواس الخمسة. الأهداف السلوكية: بعد الإنتهاء من النشاط بستطيع الطفل أن: ا ـ يذكر وظيفة كل حاسة من الحواس الخمسة. r. بوضح أهمية الحواس للأنسان. r. ب. بناقش الباحثة في أحداث المسرحية. ع. يبدي رأيه في شخصيات المسرحية. ه. يختار اسم جديد للمسرحية. T. يركب كل حاسة في مكانها الصحيح. V. يرسم الحاسة التي يفضلها. ^. يلون الحواس بألوان جميلة ومتتاسقة. 9. يختار أحد الحواس ليوضح أهميتها. المواد والأدوات: المسرح المستخدم: مسرح عرائس. شخصيات المسرحية: نوسة، الأنف، العين، الفم، الأذن، اليد. الايكور المستخدم: خلفية لحديقة بها أثجار وزهور مدة النشاط المسرحي: • r ا دقيقة خطوات النشاط: أولاً مرحلة الإعداد والتهيئة ( • د دقيقة) 
- - تبدأ الباحثة بإعداد المسرح والخلفيات. - تقوم الباحثة بإعداد المكان وجلسـة الأطفال لتصبح مناسبة للعرض، والتأكد بأن جميع الأطفال يمكنهم

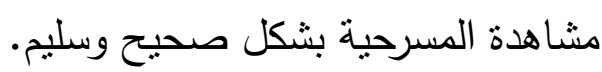

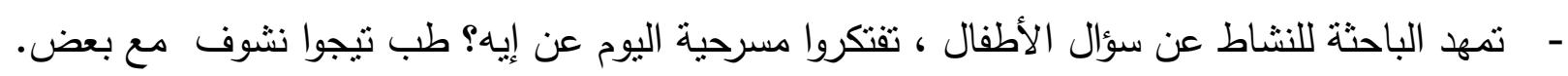
ثانيا: مرحلة التنفيذ: ( • ب دقيقة) النص الدرامي المقترح كانت نوسـة قاعدة بتلعب في الحديقة، سمعت أصـوات عالية ومتداخلة فنظرت فوجدت أصدقاءها

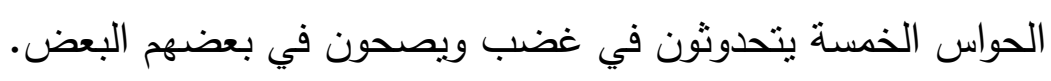

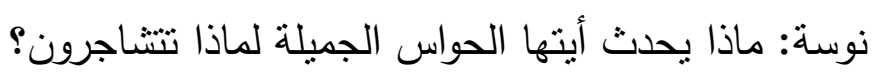
الأذن: أنا الأجمل أنا الأفضل أنا الأحسن بين الحواس.

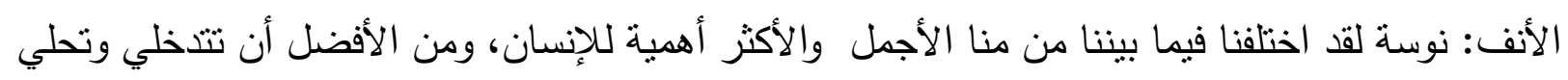
هذا الصراع وتختاري من الأفضل بينا. نوسة : إذن فلتتقام كل حاسة منكم وتذكر مميزاتها وأهميتها حتى تكون الأفضل.

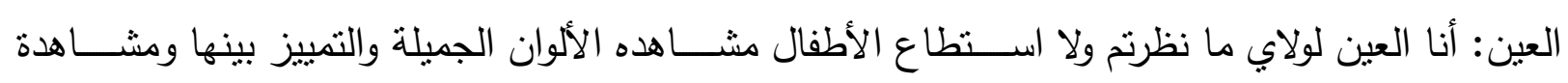
الكائنات الحية المختلفة من الأشخاص والأثجار والحيوانات والطيور والطبيعة الساحرة والرسوم الدتحركة. باقي الحواس: با لكي من مغرورة.

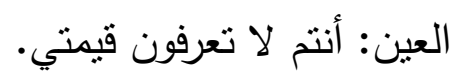

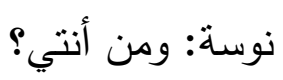

الأذن: أنا الأذن ومن لا يعرفني؟ لولاي ما سمعت الناس الأصوات واستطاعت أن تمييز بينها.

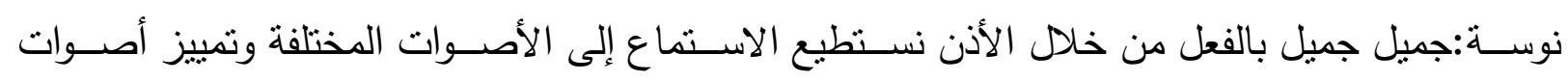
الكائنات. - الكات الأذن: ليس هذا فقط ومن خلالي يمكن تميز الأصـوات المرتفعة والمنخفضة والحادة والغليظة وأنا ضرورية جدًا للنظر . ندان. نوسة: وكيف ذلك أيتها الأذن الجميلة؟

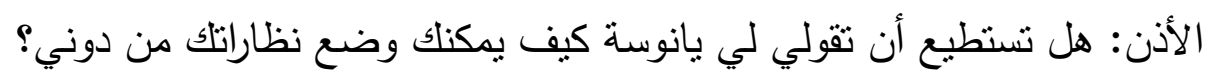

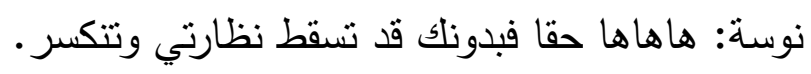
باقي الحواس: يا لكي من مغرورة يا لكي من مغرورة. الأذن: ابتعدو عني ابتعدوا عني انتوا لا تقدروني لذللك لا أريد أن أكون معكم. نوسة: ومن أنتي؟ الأنو الأنف: أنا الأنف؟ ومن آن؟؟ 
نوسة: أهلا أيتها الأنف هل يمكن أن تحديثنا عن دورك وأهميتك. الأنف: أنا المسئولة عن التتفس وشم الروائح والتمييز بينها الروائح الجيدة والكئن الكريهة.

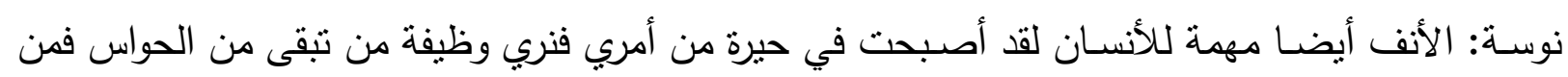
سيتقدم الأن؟ ن الأن اللسـان: لا نسألني من أنا، أنا اللسـان والمسئول عن تذوق الطعام والتمييز بين الأطعمة المختلفة كالحلو والحامض والمر ، لذلك أنا الأهم أنا الأهم. نوسة بالفعل باللسان نميز الأطعمة الحلو من العصائر والحامضة مثل الأل الليمون وغيرها، الأن لم يتبقي غير حاسة واحدة مين يا أصدقائي يعرفها.

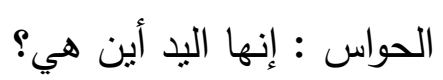

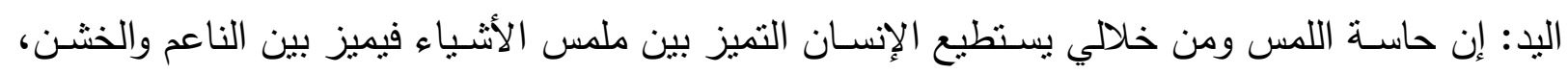

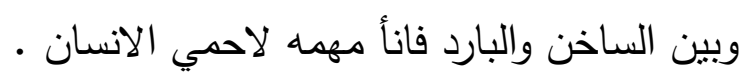

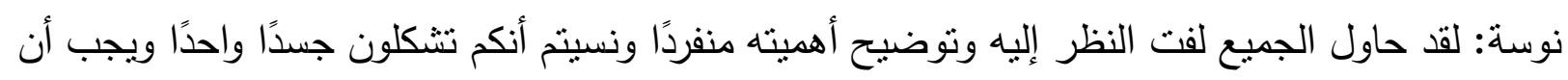

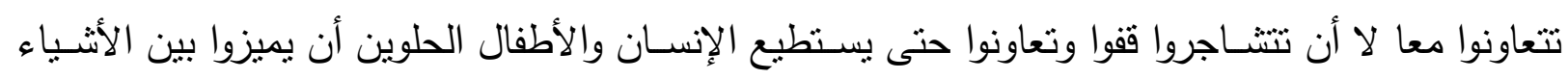

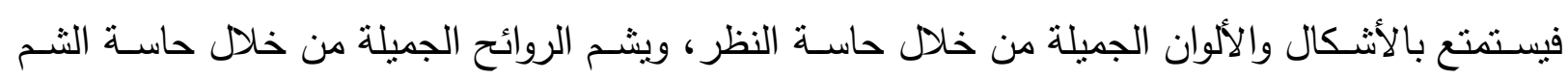

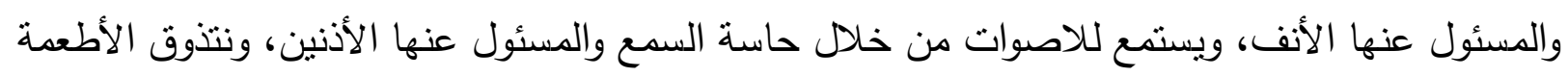

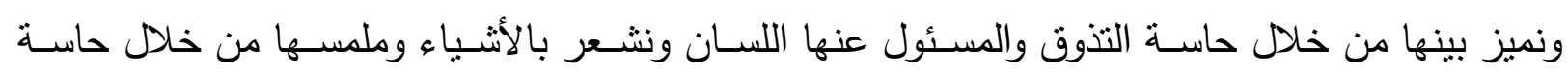
اللمس والمسئول عنها اليد، أصدقائًا كلكم مفيدون ويجب ألفأ والن تتعاونوا معًا. الحواس الخمسة:كلنا الأجمل كلنا الأفضل كلنا الأحسن.

ثالثا: مرحلة التقويم: ( • و دقيقة)

نشاط (1) نشالتا: مرعاط

نوع النشاط: لغوي مدة النشاط (· ب دقيقة) المواد والأدوات: لوحة وبرية، بطاقات عليها صور للحواس، بطاقات لوظائف الحواس. خطوات تنفيذ النشاط: تناقش الباحثة الأطفال حول مضـــون الموقف المسـرحي وتعطي لهم الفرصـــة للتعبير عن رأيهم

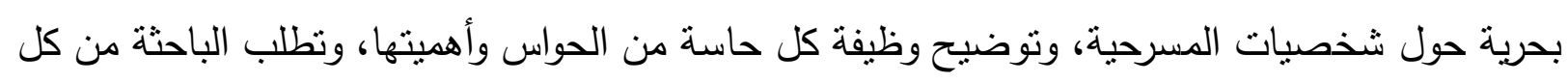

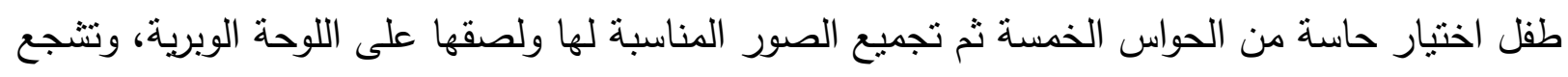
الباحثة الأطفال على المناقثة من خلادل البطاقات. نشاط (Y): ن (ب) نوع النشاط: فني مدة النشاط (• (r) دقيقة

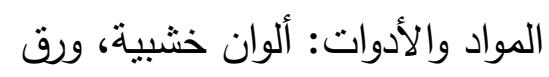




\section{خطوات تنفيذ النشاط:}

تقوم الباحثة بتتظيم جلسة الأطفال ثم تقوم بتوزبع الأوراق البيضاء على الأطفال وأقلام التلوبن وتطلب منهم رسـم الحواس ثم تلوينها بالألوان التي يفضــلونها، وتعطي لهم الوقت الكافي وبعد إنتهاء الأطفال تشــأل كل طفل عن الحاسة التي رسمها ولماذاوما هي وظيفتها ثم تقوم بمساعدتهم في لصقها علي اللوحة. وفيما يلى بعض الصور التي توضت مشاركة الأطفال عينة البحث في البرنامج الحالي:
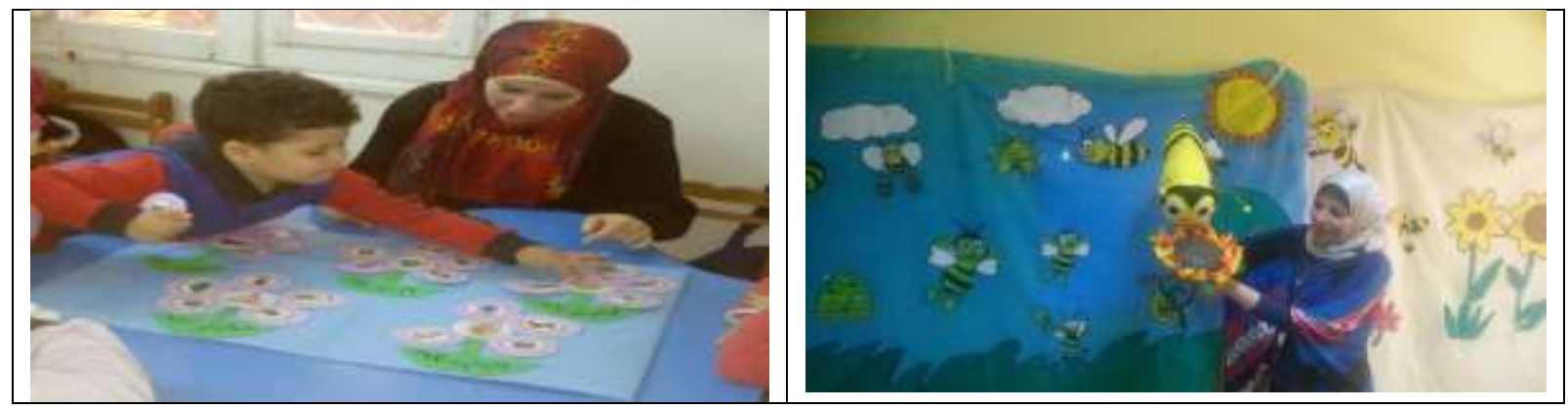

- - التجرية الاستطلاعية الأولى:

قامت الباحثة بإجراء تجربة اســنطلاعية لتجربة أدوات البحث والتأكد من صـــلاحيتها في القياس، حيث قامت بتطبيقها على ( . . () طفل وطفلة من مجتمع البحث ومن دون عينة البحث الأصـــلية لإجراء

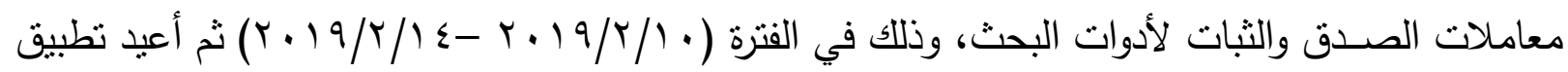
أدوات البحث (المقياس واسـتمارة الملاحظة) مرة أخرى بعد (0 (1) يوم للتحقق من ثبات الأدوات، كما قامت الباحثة بتدريب اثتان من الزميلات المسـاعدات(د.أميرة عمر -د.رانيا الدسـوقي) على كيفية تطبيق المقياس

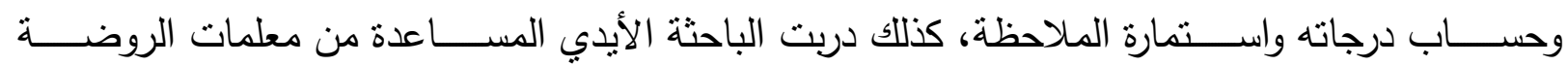
المتخصصات لمساعدة الباحثة في الأعمال الإدارية لتسجيل قوائم الأطفال وملاحظة سلوكياتهم. - - التجرية الاستطلاعية الثانية:

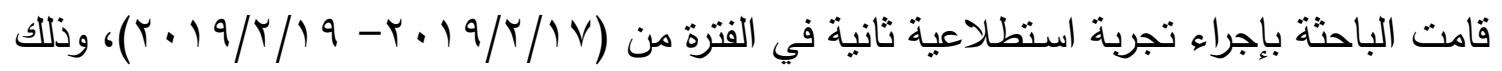

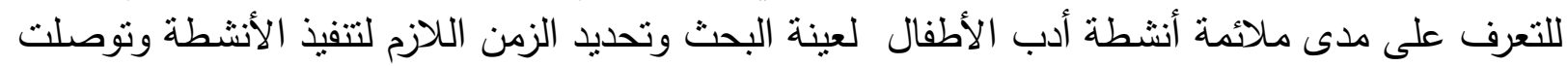

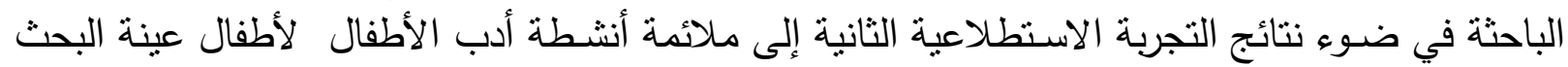

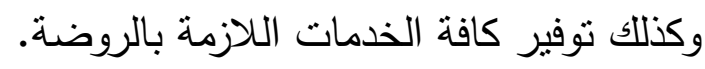
- القياس القبلي: قامت الباحثة بإجراء القياســـات القبلية لعينة البحث على "مقياس المفاهيم البيولوجية وبطاقة

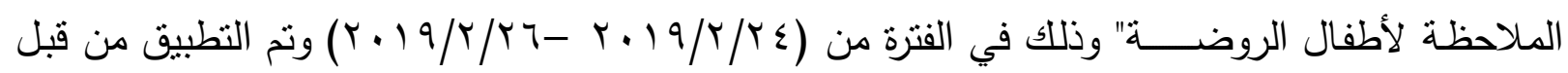

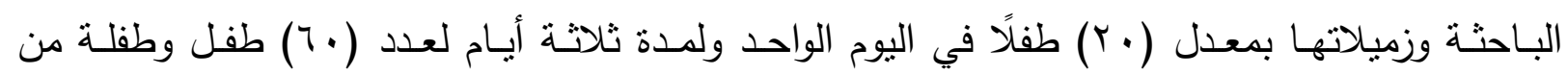
المجموعتين التجربيية والضابطة مجموعة لمدة اساعات يوميًا. - تطبيق برنامج أنشطة أدب الأطفال :

قامت الباحثة بتطبيق البرنامج المقترح والذي يتكون من ستة وحدات رئيسية تتضمن كل وحدة ستة

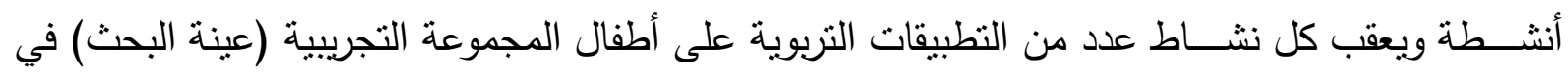




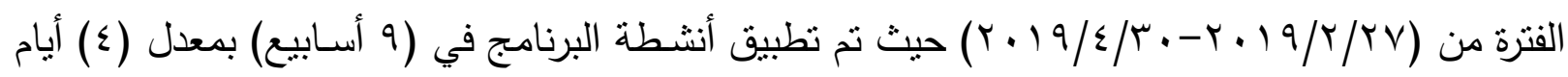

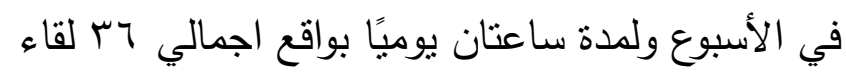
- القياس البعدي: - الاسبوع ولمدا:

قامت الباحثة بإجراء القياس البعدي لعينة البحث على مقياس الدفاهيم البيولوجية وبطاقة الملاحظة

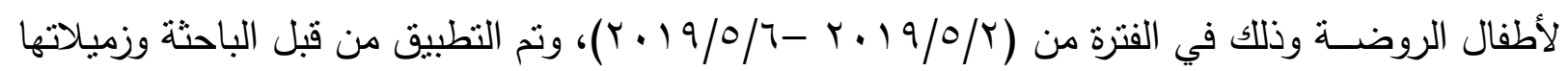

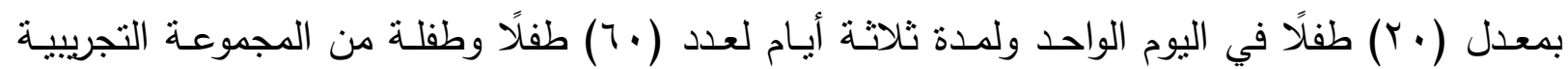
والضابطة لمدة ثلات ساعات يوميًا. - القياس التتبعي: قامت الباحثة بإجراء القياس التتبعي للمجموعة التجريبية على مقياس المفاهيم البيولوجية وبطاقة

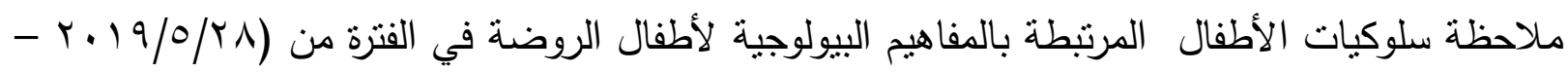

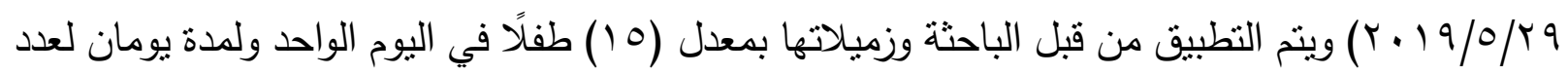

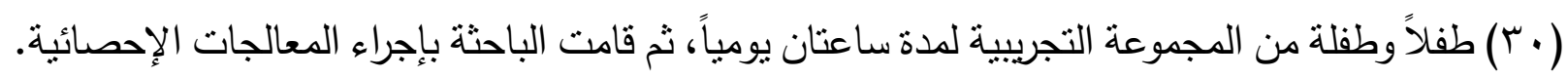

- المعالجات الإحصائية: - المانية للتجانس بين أفراد العينة 1- اختبار كا'.

للتحقق من الكفاءة السيكومترية للمقياس

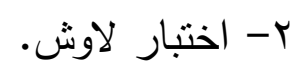

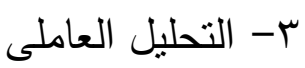
ع- معامل ألفا - كرونباخ.

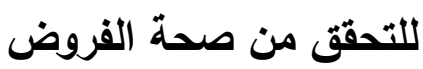
ه- اختبار (t. test) لدراسـة الفروق بين متوســـات درجات الأطفال في القياسـين القبلي والبعدي للأطفال. 1- معادلة "بلالك" لحساب نسبة الكسب المعدل (Blake Gain Ratio). V- مريع ايتا

تفسير ومناقشة نتائج البحث الفرض الاول ينص الفرض الاول على أنه : الفرض الاول

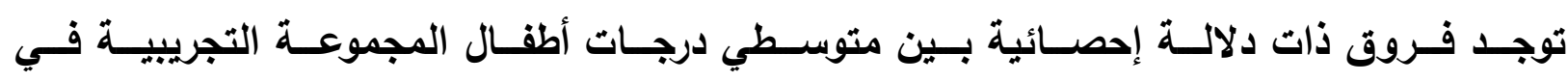

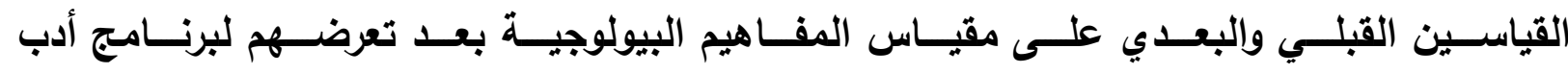
الأطفال لصالح القياس البعدي. 


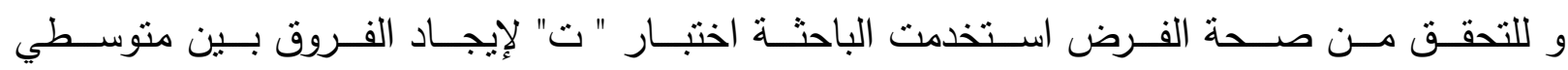

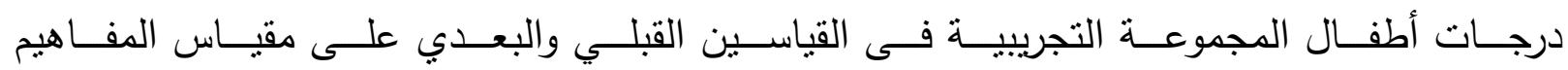

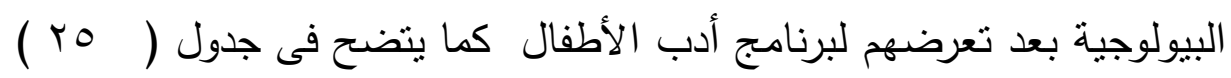
جدول ( ro )

الفروق بين منوسطي درجات أطفال المجموعة التجريبية فى القياسين القبلي والبعدي على مقياس المفاهيم البيولوجية بعد تعرضهم لبرنامج أدب الأطفال

$$
\text { r. }
$$

\begin{tabular}{|c|c|c|c|c|c|c|c|}
\hline \multirow[t]{2}{*}{ حجم الأثر } & \multirow[t]{2}{*}{ مربع ايتا } & \multirow[t]{2}{*}{ اتجاه الدلالة } & \multirow[t]{2}{*}{ مستوى } & \multirow[t]{2}{*}{ ت } & \multicolumn{2}{|c|}{ 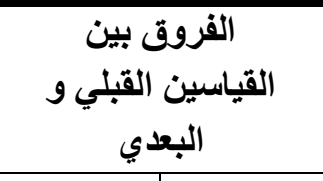 } & \multirow[t]{2}{*}{ المتغير ات } \\
\hline & & & & & مج ح ف & م ف & \\
\hline كبيز & $\cdot, 91$ & فى التجاه القياس & 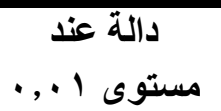 & $r \wedge, \wedge \varepsilon$ & $1, r_{1}$ & ג, & الإنسان \\
\hline كبيز & $\cdot, 99$ & فى الجاه القياس & مستوى دالة عند . . . & $79, \cdot 1$ & $\cdot, q \cdot v$ & $1 \cdot, 9 \mu r$ & النبات \\
\hline كبيز & $\cdot, 99$ & فى الجاه القياس & 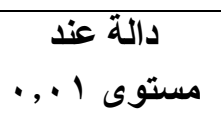 & $7 V, \leqslant 9$ & $\cdot, \wedge \wedge q$ & $1 \cdot, 97$ & الطيور \\
\hline كبيز & $\cdot, 99$ & فى الجاه القياس & 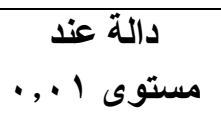 & $0 \leqslant, Y q$ & $1, .9$ & $1 \cdot, 7$ & الحشرات \\
\hline كبيز & $\cdot, 99$ & فى اتجاه القياس & 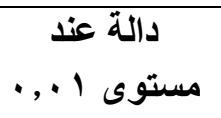 & $7 \varepsilon, 79$ & - , QYY & $1 \cdot, 9$ & والزائنات البحرية \\
\hline كبيز & $\cdot, 99$ & فى الجاه القياس & 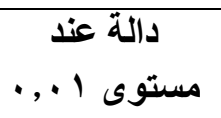 & $\Delta Q, r Y$ & $\cdot, q \wedge \vee$ & $1 \cdot, v$ & السلسلة الغذائية \\
\hline كبيز & $\cdot, 99$ & فى الجاه القياس & 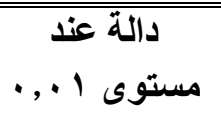 & $\overline{l Y \cdot, \Lambda}$ & r,Arq & IY,OY & الارجة الكلية \\
\hline
\end{tabular}

ت = r r r r عند مستوى I, I,

ت = צ ז, 1 عند مستوى

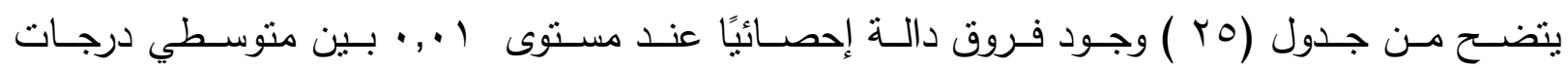

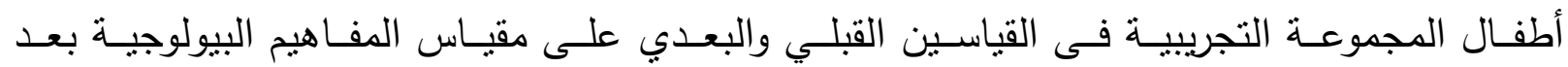
تعرضهم لبرنامج أدب الأطفال في اتجاه القياس البعدي.

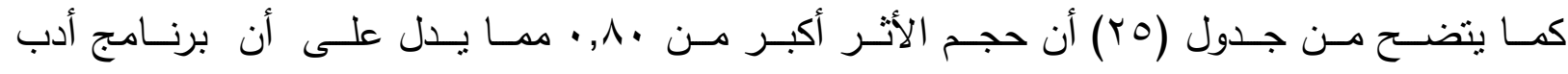

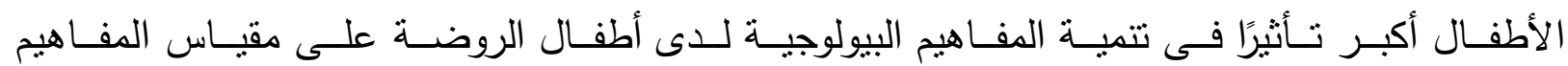
البيولوجية بعد تطبيق البرنامج.

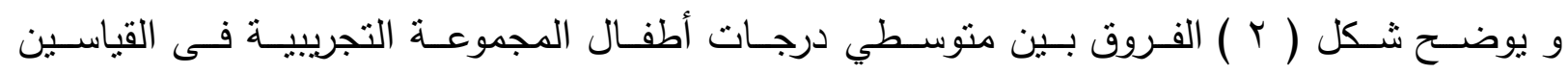
القبلي والبعدي على مقياس المفاهيم البيولوجية بعد تعرضهم لبرنامج أدب الأطفال . 


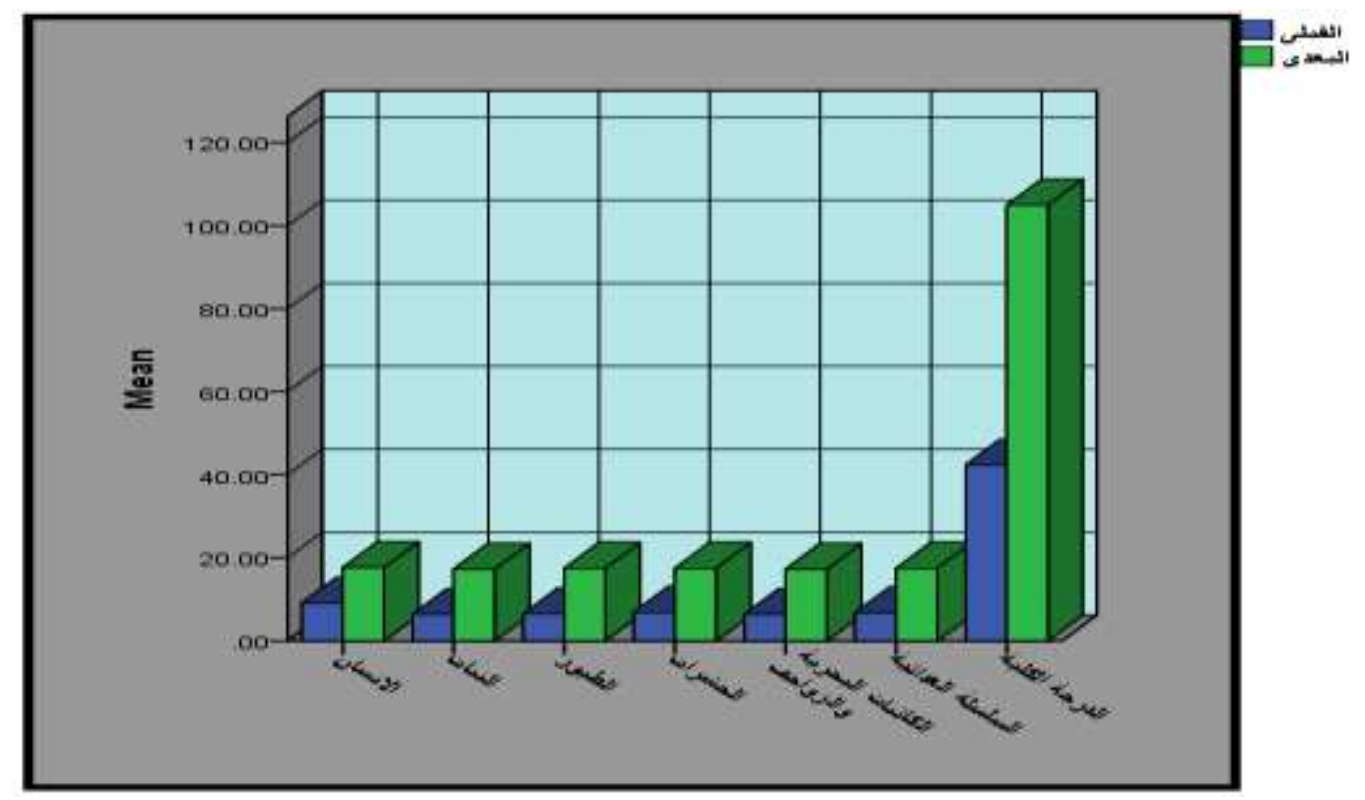

\section{شكل (r)}

الفروق بين متوسطي درجات أطفال المجموعة التجريبية فى القياسين القبلي والبعدي على مقياس المفاهيم البيولوجية

$$
\text { بعد تعرضهم لبرنامج أدب الأطفال }
$$

و للتأكـد مـن فعاليـة برنـامج أدب الأطفـال فـى تتميـة المفـاهيم البيولوجيـة بـين القياسـين القبلـي

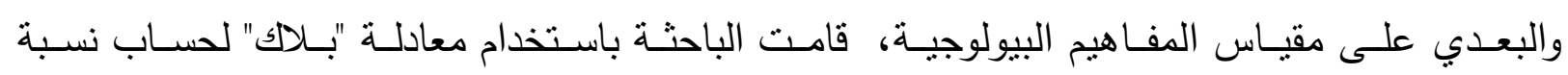

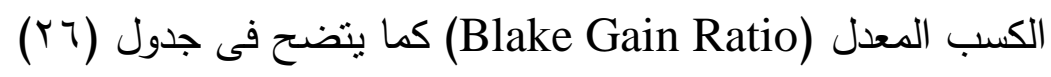

$$
\text { جدول (rT) }
$$

نتائج معادلة "بالاك" لفاعلية برنامج أدب الأطفال فى تتمية المفاهيم البيولوجية

\begin{tabular}{|c|c|c|c|c|c|}
\hline الدلالة & نسبة الكسب & النهاية العظمى & المتوسط & المجموعة & المتغيرات \\
\hline \multirow[t]{2}{*}{ ذات فاعلية } & \multirow[t]{2}{*}{$1, \leqslant \varepsilon$} & \multirow[t]{2}{*}{11} & $I r, Y \Lambda$ & البعدي & \multirow[t]{2}{*}{ الإنسان } \\
\hline & & & 9,1 & القبلي & \\
\hline \multirow[t]{2}{*}{ ذات فاعلية } & \multirow[t]{2}{*}{1,00} & \multirow[t]{2}{*}{11} & $1 Y, .0$ & البعدي & \multirow[t]{2}{*}{ النبات } \\
\hline & & & $7, \leqslant T$ & القبلي & \\
\hline \multirow[t]{2}{*}{ ذات فاعلية } & \multirow[t]{2}{*}{1,04} & \multirow[t]{2}{*}{11} & 11,94 & البعدي & \multirow[t]{2}{*}{ الطيور } \\
\hline & & & 7,07 & القبلي & \\
\hline \multirow[t]{2}{*}{ ذات فاعلية } & \multirow[t]{2}{*}{$1,0 \leqslant$} & \multirow[t]{2}{*}{11} & $1 Y, \leqslant \Lambda$ & البعدي & \multirow[t]{2}{*}{ الحشرات } \\
\hline & & & 7,94 & القبلي & \\
\hline \multirow[t]{2}{*}{ ذات فاعلية } & \multirow[t]{2}{*}{$1,0 \leq$} & \multirow[t]{2}{*}{11} & 11,90 & البعدي & \multirow{2}{*}{ والزائنات البحرية } \\
\hline & & & $7, \xi$ & القبلي & \\
\hline \multirow[t]{2}{*}{ ذات فاعلية } & \multirow[t]{2}{*}{1,00} & \multirow[t]{2}{*}{11} & $1 Y, \xi$ & البعدي & \multirow[t]{2}{*}{ السلسلة الغذائية } \\
\hline & & & $\checkmark, \wedge r$ & القبلي & \\
\hline \multirow[t]{2}{*}{ ذذات فاعلية } & \multirow{2}{*}{1,01} & \multirow[t]{2}{*}{$1 \cdot 1$} & $V \leqslant, 10$ & البعدي & \multirow[t]{2}{*}{ الارجة الكلية } \\
\hline & & & $\varepsilon Y, \varepsilon r$ & القبلي & \\
\hline
\end{tabular}
بين القياسين القبلي والبعدي على مقياس المفاهيم البيولوجية 


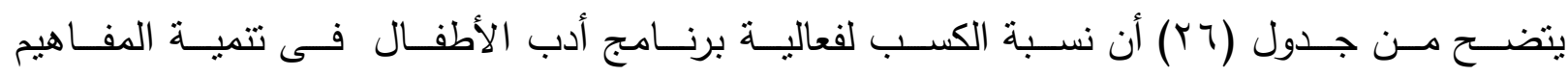

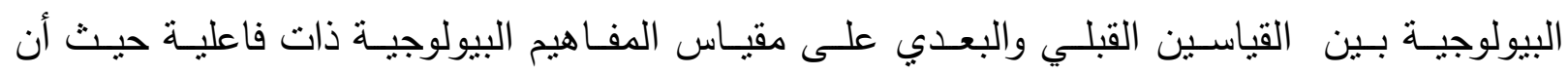

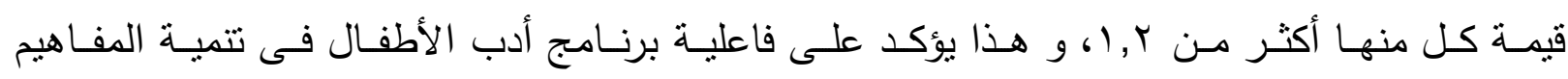
البيولوجية.

تعزو الباحثه هذه النتيجة إلى نجاح برنامج البحث الحالي بما يتضمنه من (قصص الأطفال -

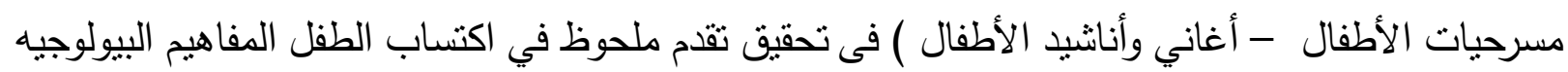

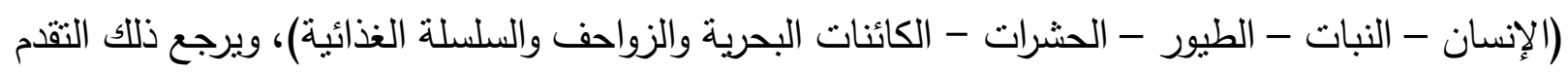

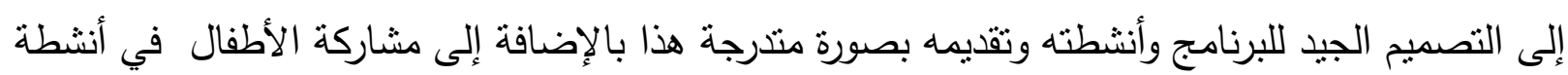

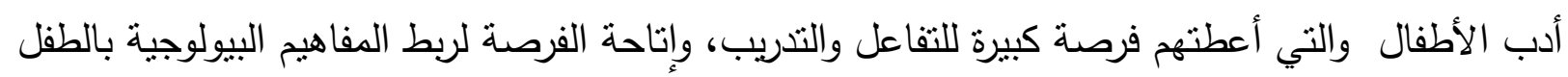

وبيئته.

وهذا يتفق مع ما أكدت عليه دراسة كلا من (Sackes, 2009) التي أثنارت إلى فاعلية أدب الطفل

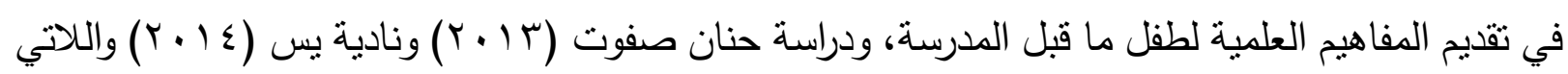
أكدا على أهمية أدب الأطفال في تتمية المفاهيم التاريخية لمصر الفرعونية والمفاهيم الإيجابية لاي طفل الروضة.

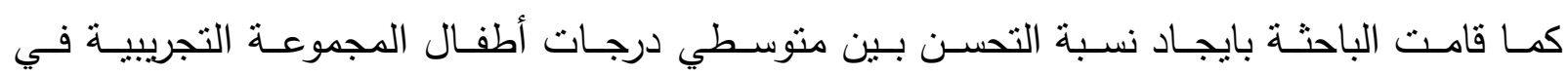

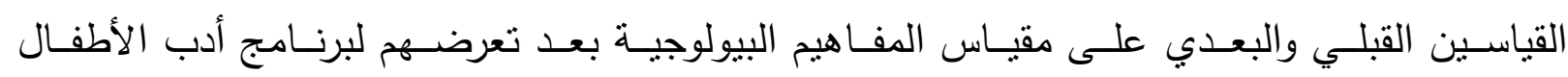

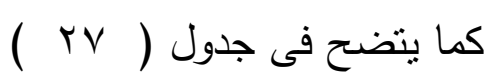

$$
\text { جدول ( ) ( ) }
$$

نسبة التحسن بين منوسطي درجات أطفال المجموعة التجريبية فى القياسين القبلي والبعدي على مقياس

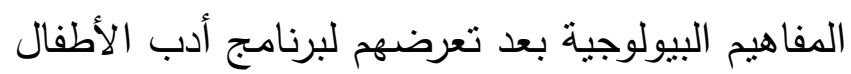

\begin{tabular}{|c|c|c|c|}
\hline التحسبة & القبلي & البجدياس & المتفيرات \\
\hline$\% \leqslant \wedge, 0$ & 9,1 & IV,V & الإنسان \\
\hline$\% 4$ & $7, \xi$ & $\overline{l v, r}$ & النبات \\
\hline$\%$ \% & 7,0 & $i v, 0$ & الطيور \\
\hline$\% \curlyvee, 0$ & 8,9 & IV,O & الحشرات \\
\hline$\% 4 r$ & $\checkmark, \xi$ & $i v, r$ & الكائنات البحرية والزوواحف \\
\hline$\% \square, 1$ & 8,1 & $i v, 0$ & السلسلة الغذائية \\
\hline 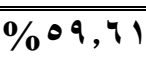 & $\varepsilon r, \xi$ & 1.0 & الارجة الكلية \\
\hline
\end{tabular}

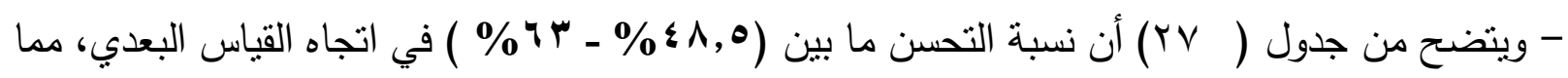
يؤكد على نجاح برنامج أدب الأطفال بما يتضمنه من (قصص الأطفال- مسرحيات الأطفال- أغاني وأناشيد 
الأطفال) وظهر ذلك في أسئلة الأطفال واستجاباتهم ففي بداية التطبيق لم يستطع الطفل تكوين سلسلة غذائية ومع التدريب والأنشطة تمكن الأطفال من تكوين سلاسل غذائية، حيث ردد الطفل (أ. م) عبارة يلا نعمل السلسلة الغذائية وبدايتها كائن منتج، كذلك أيضًا أنثاء فترة تتاول الطعام ردد أحد الأطفال إحنا بنأكل بفمنا

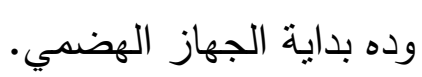
وتعزو الباحثة هذا التحسن إلى الدور الفعال للبرنامج وما يتمتع به من تتظيم للمحتوى بشكل واضح

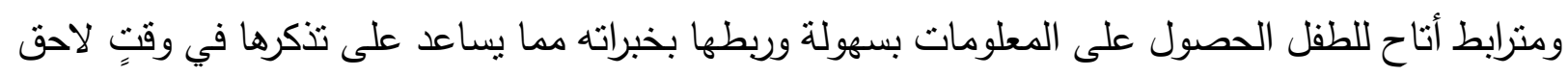
هذا بالإضافة إلى تتوع الاستراتيجيات التعليمية وتتوع أنثطة البرنامج وتدرجها في تقديم المفهوم (المعلومة)

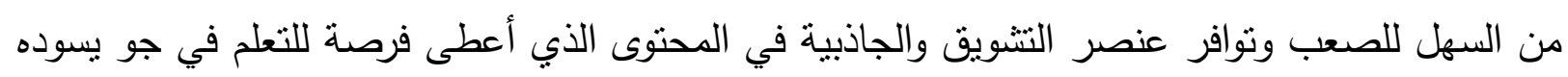
البهجة والراحة النفسية. وهذا يتقق على ما أكدت عليه دراسة (Enciso et al, 2010) والتي أكدت على أن أدب الأطفال

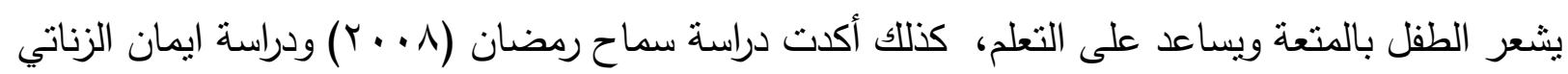

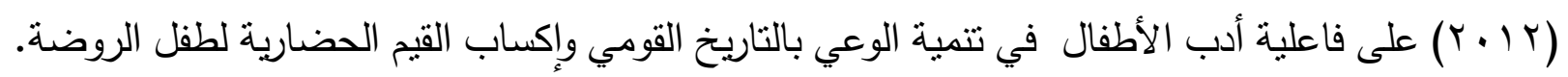
وتخلص الباحثة مما سبق إلى تحقق صحة الفرض الأول. الفرض الثانى

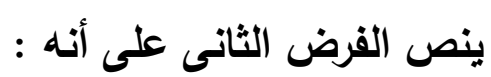

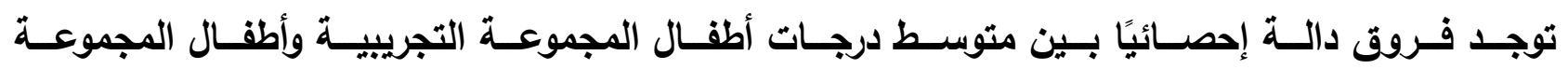

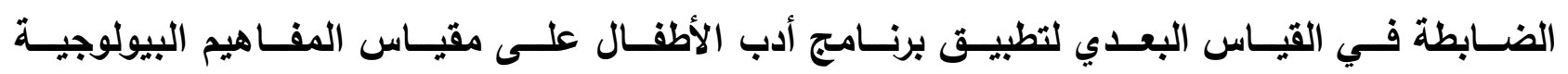
لصالح المجموعة التجريبية. و للتحقق من صحة الفرض استخدمت الباحثة اختبار " ت"لايجاد الفروق بين متوسط درجات أطفال المجموعة التجريبية وأطفال المجموعة الضـــابطة، في القياس البعدي لنطبيق برنامج أدب الأطفال على مقياس الدفاهيم البيولوجية كما يتضح فى جدول (rV) 


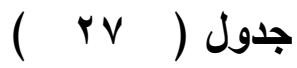

الفروق بين متوسط درجات أطفال المجموعة التجريبية وأطفال المجموعة الضابطة، في القياس البعدي لتطبيق برنامج أدب الأطفال على مقياس المفاهيم البيولوجية

$7 \cdot=\dot{0}$

\begin{tabular}{|c|c|c|c|c|c|c|c|c|c|}
\hline \multirow[t]{2}{*}{ حجم الأثر } & \multirow[t]{2}{*}{ مربع ايتا } & \multirow[t]{2}{*}{ اتجاه الدلالة } & \multirow[t]{2}{*}{ مستوى الالاية } & \multirow[t]{2}{*}{ ت } & \multicolumn{2}{|c|}{ الضابطة المجة } & \multicolumn{2}{|c|}{ التجريبية } & \multirow[t]{2}{*}{ المتغيرات } \\
\hline & & & & & $r \varepsilon$ & $t^{p}$ & ع & م & \\
\hline كبير &., 90 & التجريبية & دالة عند مستوى & $r v, 11$ & $1, r$ & $\Lambda, \wedge \mu$ & $\cdot, 0 Y$ & $I V, V Y$ & الإنسان \\
\hline كبير & $\cdot, 91$ & التجريبية & دالة عند مستوى & $\Delta \leqslant, V \Psi$ & $\cdot, \vee \wedge$ & $\neg, V r$ & $\cdot, v_{1}$ & IV,rq & النبات \\
\hline كبير & $\cdot, 91$ & التجريبية & دالة عند مستوى & $T V, Y \leq$ &., $0 \leqslant$ & Y, r & $\cdot, V T$ & $I V, O r$ & الطيور \\
\hline كبير & $\cdot, 9 \mathrm{~V}$ & التجريبية & دالة عند مستوى & $\varepsilon r, O r$ & $\cdot, 9 \mathrm{~V}$ & $V, \varepsilon r$ & $\cdot, \wedge 1$ & $I V, O M$ & الحشرات \\
\hline كبير & $\cdot, 91$ & التجريبية & دالة عند مستوى & $\Delta \leqslant, O Y$ & $\cdot, V Y$ & 7,7 & $\cdot, \vee \vee q$ & IV,r & والزائنات البحرية \\
\hline كبير & $\cdot, 91$ & التجريبية & دالة عند مستوى & $\theta \&, \varphi_{0}$ & $\cdot, \wedge$ & $V, r q$ & • & IV,OT & السلسلة الغذائية \\
\hline كبير &., 99 & التجريبية & دالة عند مستوى & IYV,rY & $1,7 \varepsilon$ & $\overline{\varepsilon r, r}$ & $r, \cdot \Lambda$ & 1.0 & الارجة الكلية \\
\hline
\end{tabular}

ت = Y, Y Y

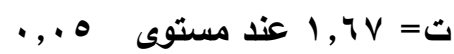

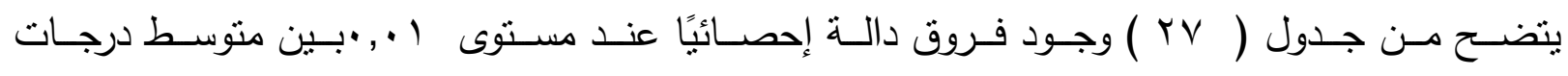

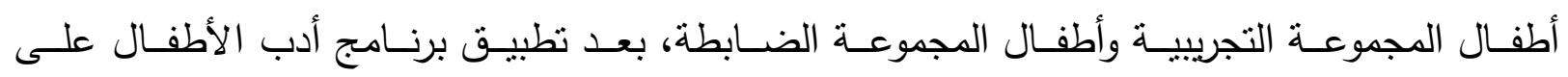
مقياس المفاهيم البيولوجية لصالح المجموعة التجريبية.

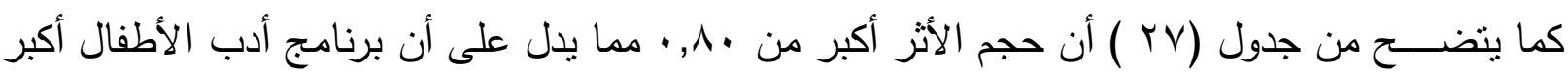

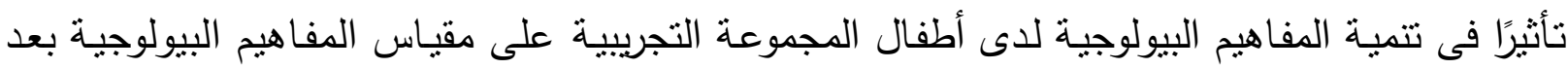
تطبيق البرنامج.

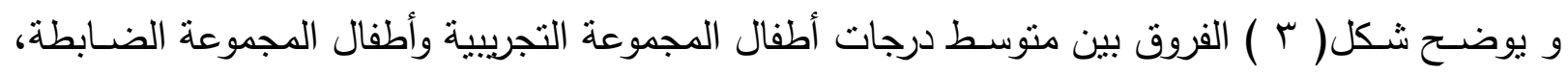
بعد تطبيق برنامج أدب الأطفال على مقياس الدفاهيم البيولوجية. 


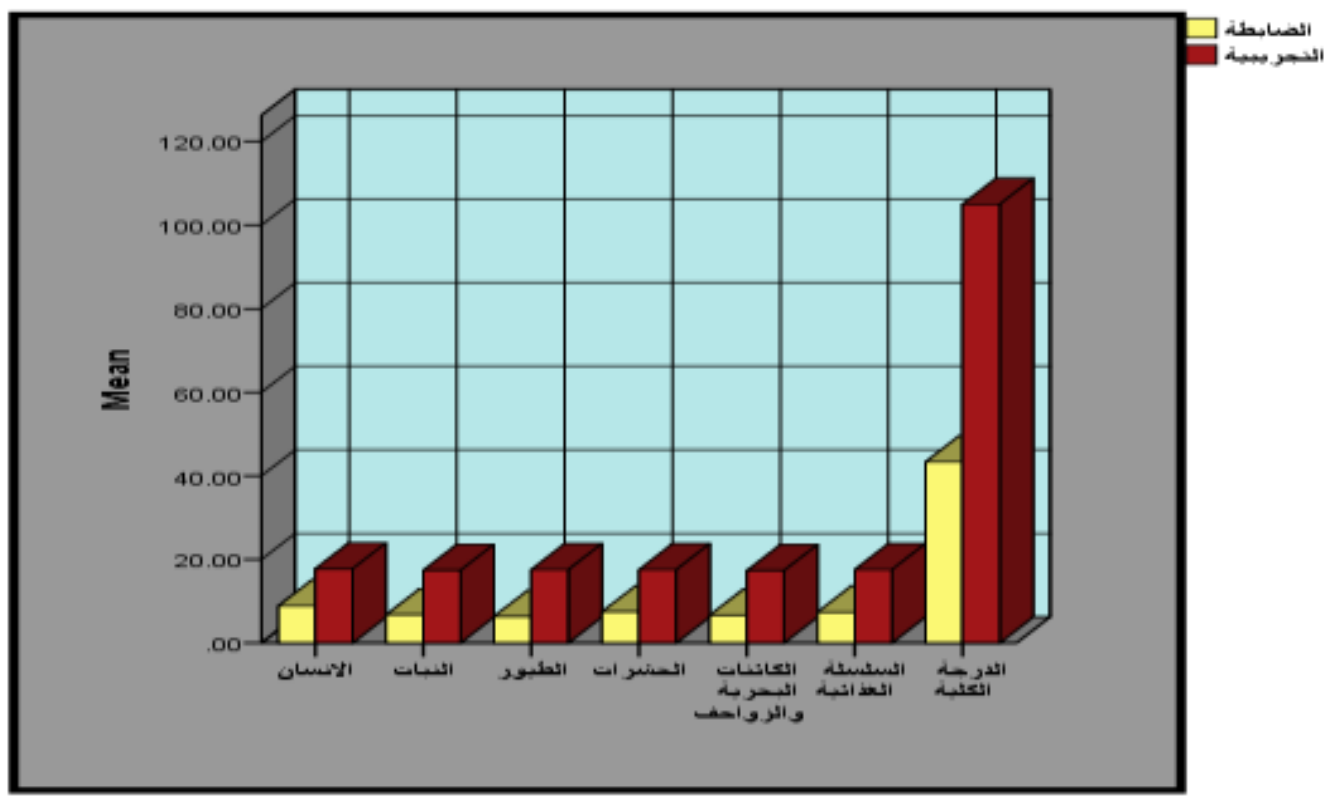

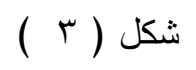

الفروق بين متوسط درجات أطفال المجموعة التجريبية وأطفال المجموعة الضابطة، بعد نطبيق برنامج أدب الأطفال على مقياس المفاهيم البيولوجية

و للتأكد من فعالية برنامج أدب الأطفال فى تتمية المفاهيم البيولوجية لدى أطفال المجموعة التجريبية على مقياس المفاهيم البيولوجية، قامت الباحثة باسـتخدام معادلة "بلاكك" لحسـاب نسـبة الكسـب المعدل

(rᄉlake Gain Ratio)

جدول (rᄉ)

نتائج معادلة "بالك" لفاعلية برنامج أدب الأطفال فى تتمية المفاهيم البيولوجية

لاى أطفال المجموعة التجربيية على مقياس المفاهيم البيولوجية

\begin{tabular}{|c|c|c|c|c|c|}
\hline |الدلالة & نسبةٌ الكسب & النهاية العظمى & المتوسط & المجموعة & المتغيرات \\
\hline \multirow[t]{2}{*}{ ذات فاعلية } & \multirow[t]{2}{*}{$1, \leqslant 7$} & \multirow[t]{2}{*}{11} & $I r, Y \Lambda$ & التجريبية & \multirow[t]{2}{*}{ الإنسان } \\
\hline & & & $\Lambda, \wedge r$ & الضابطة & \\
\hline \multirow[t]{2}{*}{ ذات فاعلية } & \multirow[t]{2}{*}{1,04} & \multirow[t]{2}{*}{11} & $1 Y, .0$ & التجريبية & \multirow[t]{2}{*}{ النبات } \\
\hline & & & $\checkmark, V Y$ & الضابطة & \\
\hline \multirow[t]{2}{*}{ ذذات فاعلية } & \multirow[t]{2}{*}{1,01} & \multirow[t]{2}{*}{11} & 11,94 & التجريبية & \multirow[t]{2}{*}{ الطيور } \\
\hline & & & T, & الضابطة & \\
\hline \multirow[t]{2}{*}{ ذات فاعلية } & \multirow[t]{2}{*}{1,01} & \multirow[t]{2}{*}{11} & $I Y, \varepsilon \wedge$ & التجريبية & \multirow[t]{2}{*}{ الحشرات } \\
\hline & & & $V, \varepsilon r$ & الضابطة & \\
\hline \multirow[t]{2}{*}{ ذذات فاعلية } & \multirow[t]{2}{*}{1,04} & \multirow[t]{2}{*}{11} & 11,90 & التجريبية & \multirow{2}{*}{ والكائنات البحرية } \\
\hline & & & 7,7 & الضابطة & \\
\hline \multirow[t]{2}{*}{ ذات فاعلية } & \multirow[t]{2}{*}{1,01} & \multirow[t]{2}{*}{11} & $1 Y, \leqslant 0$ & التجريبية & \multirow{2}{*}{ السلسلة الغذائية } \\
\hline & & & $V, r q$ & الضابطة & \\
\hline \multirow[t]{2}{*}{ ذذات فاعلية } & \multirow{2}{*}{$1,0 Y$} & \multirow[t]{2}{*}{$1 \cdot 1$} & $V \leqslant, 10$ & التجريبية & \multirow[t]{2}{*}{ الارجة الكلية } \\
\hline & & & $\varepsilon r, r$ & الضابطة & \\
\hline
\end{tabular}




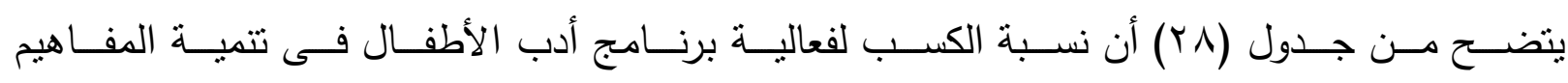

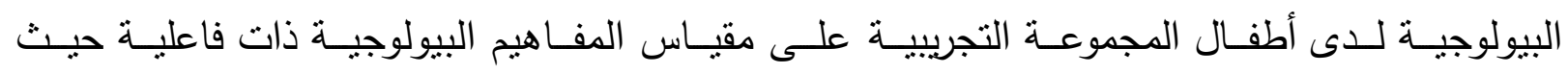

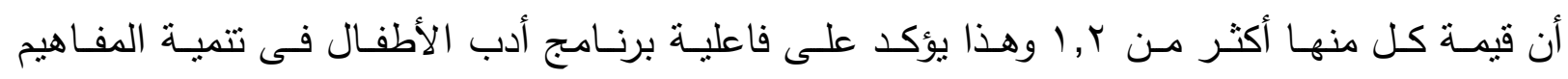
البيولوجية لدى أطفال المجموعة التجريبية على مقياس المفاهيم البيولوجية.

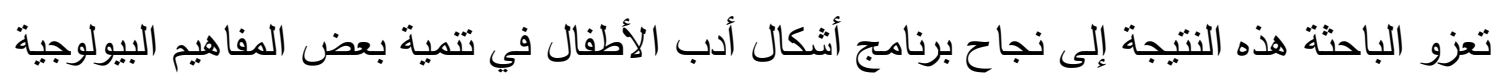

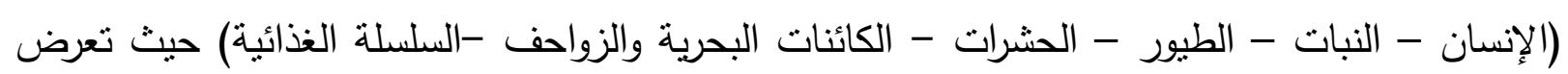

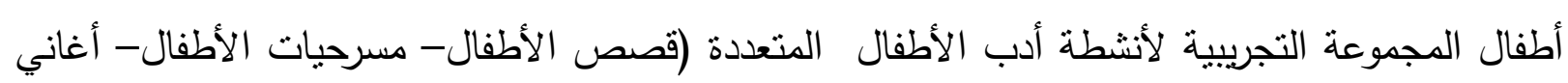

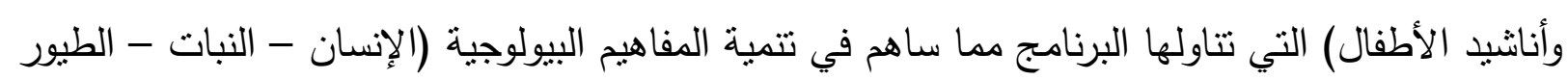

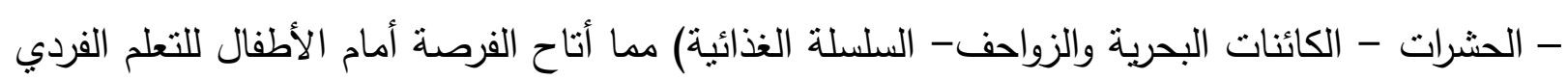

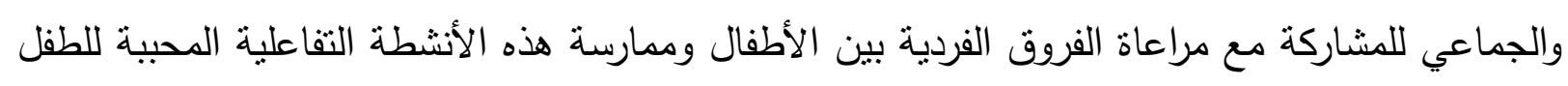
في جو يسوده المرح والترفيه. في حين لم تطرق أطفال المجموعة الضابطة لمتل هذه الأنشطة الني تهنم بالمفاهيم البيولوجية

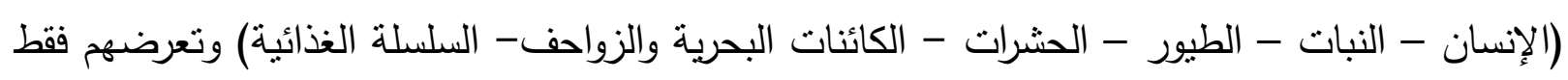
لأنشطة برنامج الروضة التقليدي. وتتفق هذه النتائج مع ما أنشار إليه الإطار النظري والدراسات السابقة حيث أكد سمير عبد الوهاب

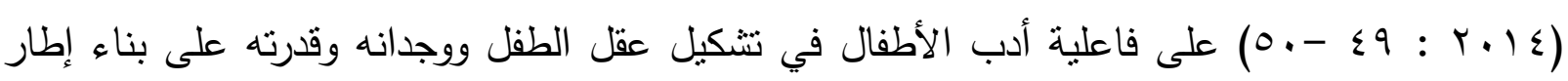
معرفي لدي الطفل.

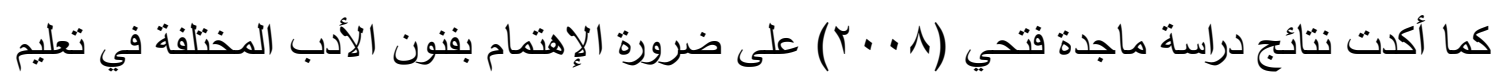

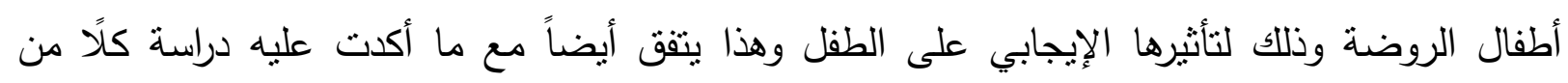

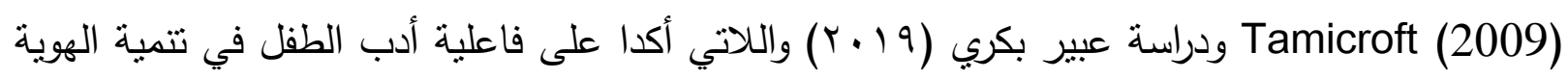
الثقافية والمهارات الحياتية لطفل الروضة. وتخلص الباحثة مما سبق إلى تحقق صحة الفرض الثاني. ينص الفرض الثالث على انه :

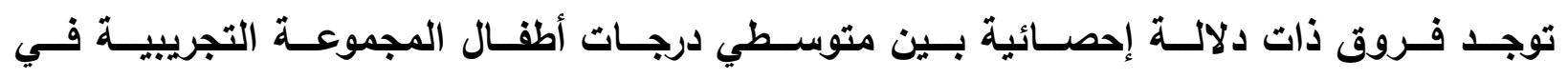

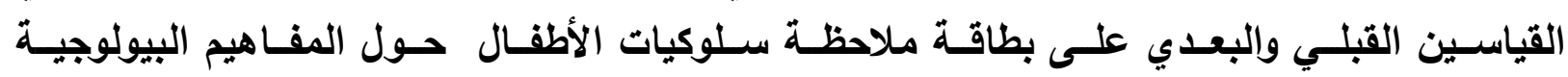
بعد تعرضهم لبرنامج أدب الأطفال لصالح القياس لطاف البعدي. 


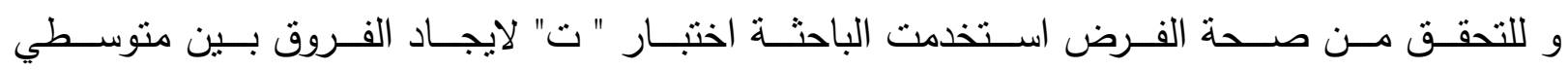

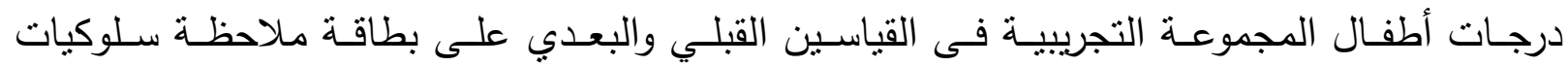

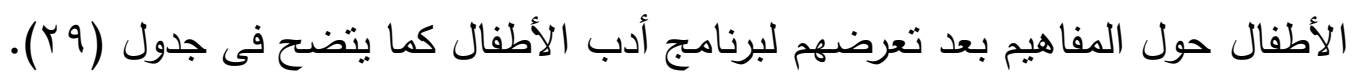

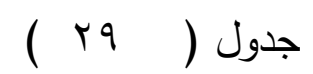

الفروق بين متوسطي درجات أطفال المجموعة التجريبية فى القياسين القبلي والبعدي على بطاقة ملاحظة سلوكيات الأطفال حول المفاهيم بعد تعرضهم لبرنامج أدب الأطفال

$$
r \cdot=\dot{0}
$$

\begin{tabular}{|c|c|c|c|c|c|c|c|}
\hline \multirow[t]{2}{*}{ حجم الأثر } & \multirow[t]{2}{*}{ مربع ايتا } & \multirow[t]{2}{*}{ اتجاه الدلالة } & \multirow[t]{2}{*}{ مستوى } & \multirow[t]{2}{*}{ ت } & \multicolumn{2}{|c|}{ 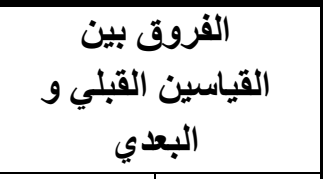 } & \multirow[t]{2}{*}{ المتغيرات } \\
\hline & & & & & مجج حف & م ف & \\
\hline كبير & $\cdot ., 99$ & فى الجباه القياس & 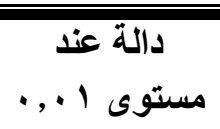 & $O V, \Lambda Y$ & $\overline{\cdot ?, \wedge \wedge}$ & $\overline{Q 9, r r}$ & الإنسان \\
\hline كبير & $\cdot, 99$ & فى الجباه القياس & مستوى دالة عذد. & $r \cdot, Y$ & $\cdot, \Lambda \mu$ & 9,17 & النبات \\
\hline كبير &., 99 & فى الجباه القياس & مستوى ل ا.., . & $v_{1, \varepsilon}$ & $\cdot, \mathrm{VI}$ & $9, \Gamma 4$ & الطيور \\
\hline كبير & $\cdot, 99$ & فى الجاه القياس & مستوى ل .., . & $v 1, \varepsilon$ & $\cdot, V Y$ & $9, \xi$ & الحشرات \\
\hline كبيز &., 99 & فى الجباه القيّاس & مستوى لدالة عـد. & $v \cdot, q$ & $\cdot, V Y$ & $9, \leqslant \psi$ & والزاناحف البحرية \\
\hline كبير & $\cdot, 99$ & فى اتجاه القياس & مستوى 1 .,. & $\checkmark \backslash, \wedge \Lambda$ & $\cdot, \mathrm{V}_{1}$ & $9, r 4$ & السلسلة الغذائية \\
\hline كبير &., 99 & فى الجباه القياس & مستوى لد الد. . & $\backslash \wedge \wedge, r \wedge$ & $\overline{1, T Y}$ & $04, \cdot r$ & |الدرجة | \\
\hline
\end{tabular}

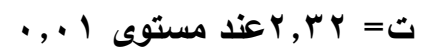

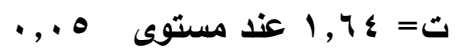

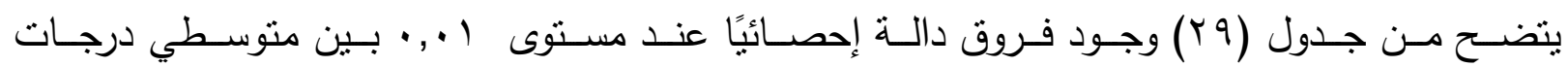

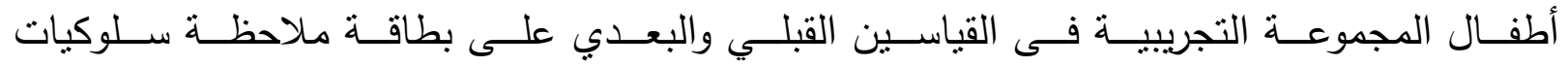
الأطفال حول المفاهيم بعد تعرضهم لبرنامج أدب الأطفال فى اتجاه القياس البعدي.

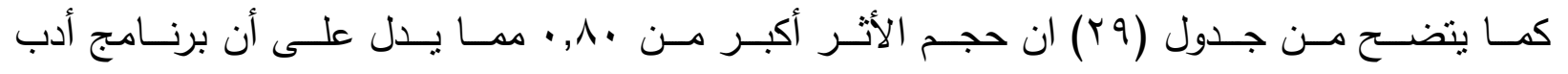

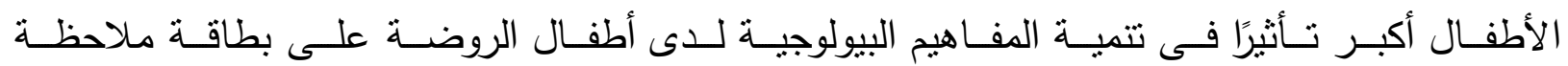
سلوكيات الأطفال حول المفاهيم بعد تطبيق البرنامج. 
و يوضـح شـكل ( ع ) الفـروق بـين متوسـطي درجـات أطفـال المجموعـة التجريبيـة فـى القياسـين

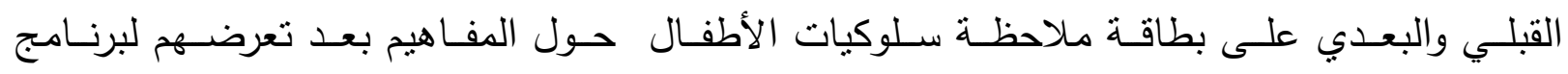

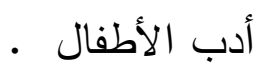

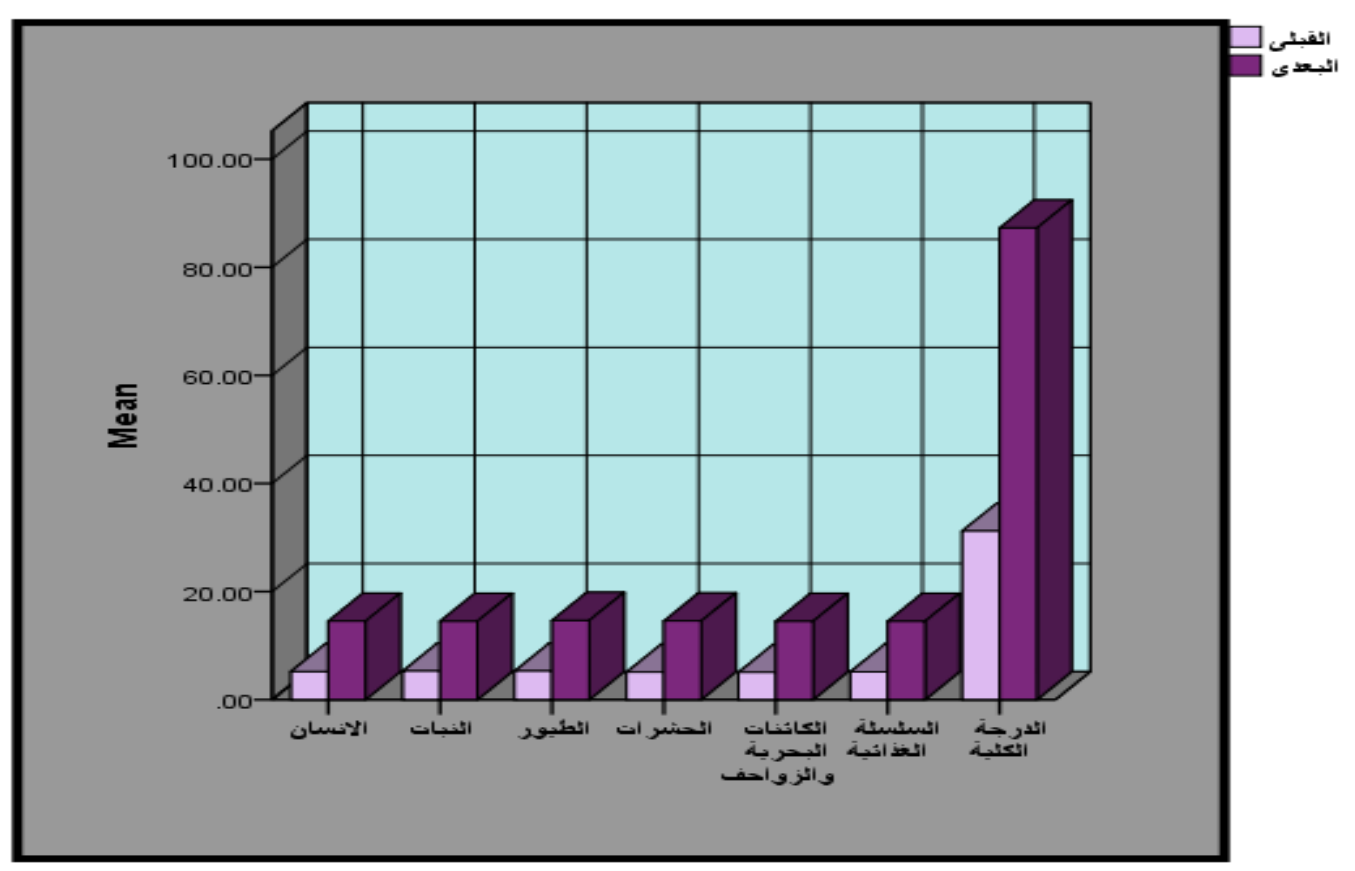

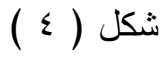

الفروق بين متوسطي درجات أطفال المجمعة التجريبية فى القياسين القبلي والبعدي بطاقة ملاحظة سلوكيات الأطفال حول المفاهيم بعد تعرضهم لبرنامج أدب الأطفال

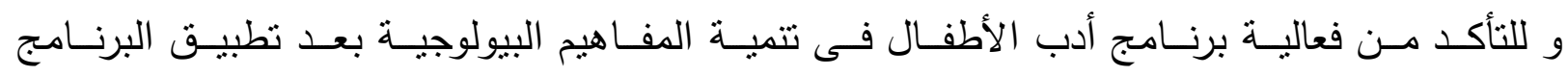

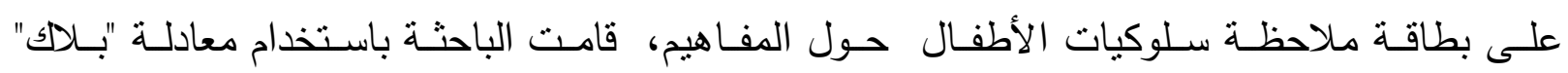

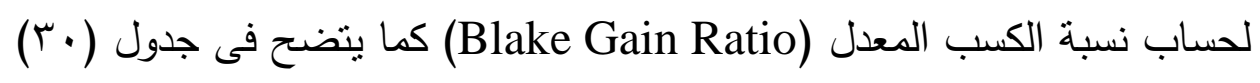




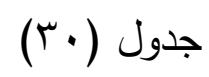

نتائج معادلة "بلالك" لفاعلية برنامج أدب الأطفال فى تتمية المفاهيم البيولوجية

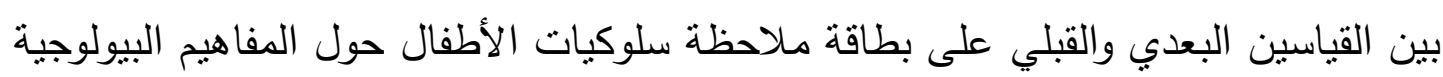

\begin{tabular}{|c|c|c|c|c|c|}
\hline الدلالة & نسبة الكسب & النهاية العظمى & المتوسط & المجموعة & |المتغيرات \\
\hline \multirow{2}{*}{ ذات فاعلية } & \multirow[t]{2}{*}{$1,0 \mathrm{~V}$} & \multirow[t]{2}{*}{10} & $1 \leqslant, O r$ & البعدي & \multirow{2}{*}{ الإنسان } \\
\hline & & & $0, r$ & القبلي & \\
\hline \multirow[t]{2}{*}{ ذذات فاعلية } & \multirow[t]{2}{*}{1,00} & \multirow[t]{2}{*}{10} & $1 \leqslant, 0$ & البعدي & \multirow[t]{2}{*}{ النبات } \\
\hline & & & $0, r \mu$ & القبلي & \\
\hline \multirow[t]{2}{*}{ ذذات فاعلية } & \multirow[t]{2}{*}{1,09} & \multirow[t]{2}{*}{10} & $1 \varepsilon, 74$ & البعدي & \multirow[t]{2}{*}{ الطيور } \\
\hline & & & $0, r$ & القبلي & \\
\hline \multirow[t]{2}{*}{ ذذات فاعلية } & \multirow[t]{2}{*}{1,01} & \multirow[t]{2}{*}{10} & $1 \varepsilon, 04$ & البعدي & \multirow[t]{2}{*}{ |الحشرات } \\
\hline & & & 0,17 & القبلي & \\
\hline \multirow[t]{2}{*}{ ذات فاعلية } & \multirow[t]{2}{*}{$1,0 \mathrm{~V}$} & \multirow[t]{2}{*}{10} & $1 \leqslant, 0$ & البعدي & \multirow{2}{*}{ والكوائنات البحرية } \\
\hline & & & $0, .7$ & القبلي & \\
\hline \multirow[t]{2}{*}{ ذذات فاعلية } & \multirow[t]{2}{*}{$1,0 \mathrm{~V}$} & \multirow[t]{2}{*}{10} & $1 \leqslant, 0$ & البعدي & \multirow[t]{2}{*}{ السلسلة الغذائية } \\
\hline & & & 0,17 & القبلي & \\
\hline \multirow[t]{2}{*}{ ذذات فاعلية } & \multirow{2}{*}{$1,0 \mathrm{~V}$} & \multirow{2}{*}{9.} & AV,Y & البعدي & \multirow[t]{2}{*}{ الارجة الكلية } \\
\hline & & & 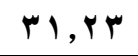 & القبلي & \\
\hline
\end{tabular}

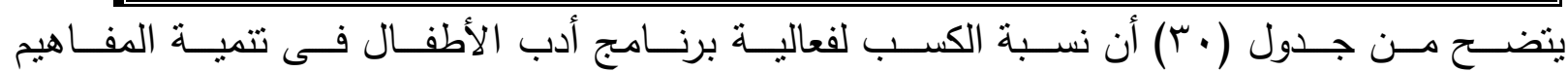

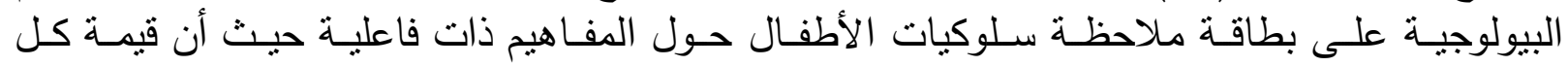

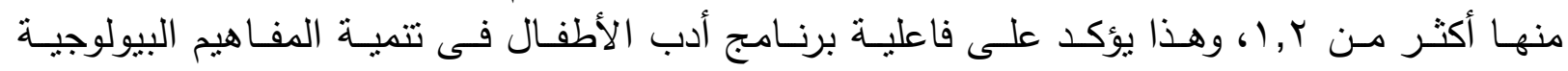

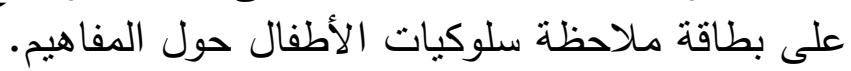

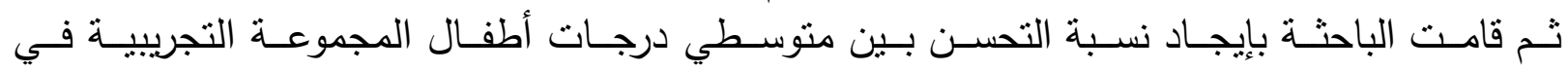

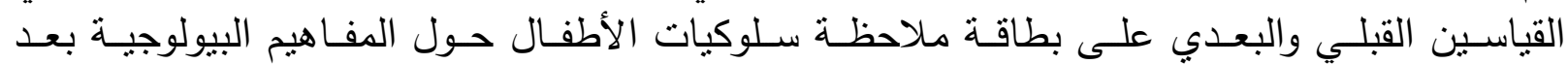

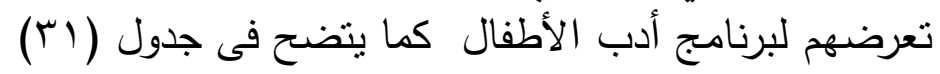
جدول (rال)

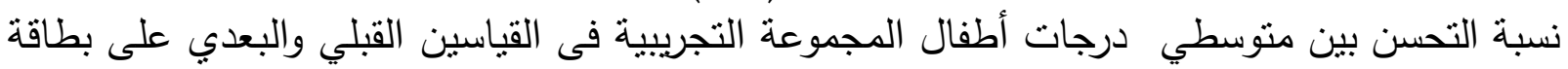

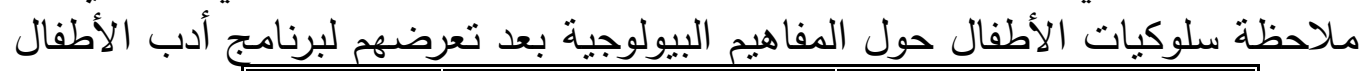

\begin{tabular}{|c|c|c|c|}
\hline التحسن & القبياس & البعدي & المتفيرات \\
\hline$\% \curlyvee\{, Y)$ & $0, r$ & $1 \leqslant, 04$ & الإنسان \\
\hline \%ऑr, & $0, r$ & $1 \leqslant, 0$ & 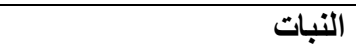 \\
\hline 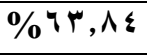 & $0, \Gamma$ & $1 \varepsilon, 74$ & الطيور \\
\hline$\% \backslash \leqslant, q$ & 0,1 & $1 \&, 04$ & | الحشرات \\
\hline$\% \uparrow 0,1$ & $0, .4$ & $1 \leqslant, 0$ & الكاننات البحرية والزواحف \\
\hline$\%$ \%ะ, & 0,19 & $1 \leqslant, 0$ & |السلسلة الغذائية \\
\hline$\%$ \%ध,Y\} & $r \bar{r}, \mathrm{r}$ & $\Lambda V, Y \Psi$ & الالرجة الكلية \\
\hline
\end{tabular}

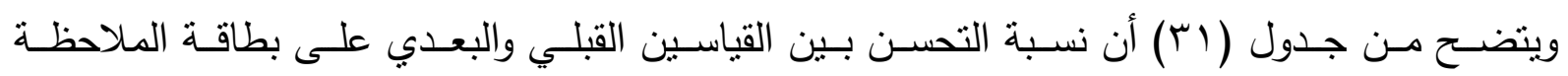

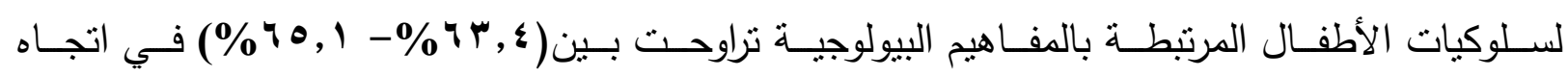




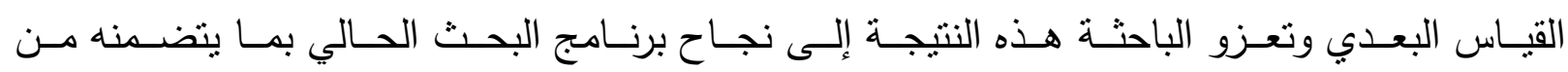

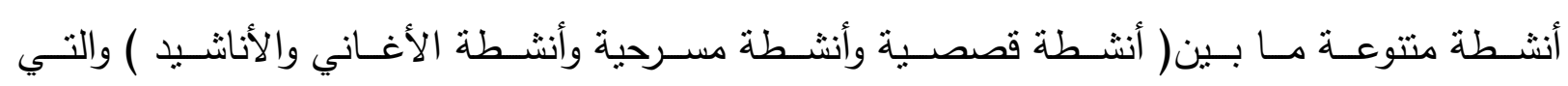

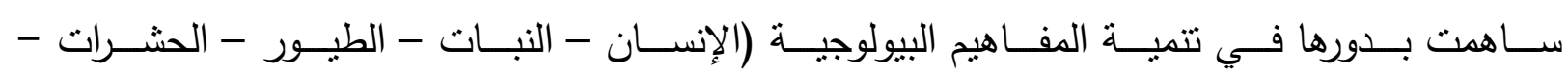

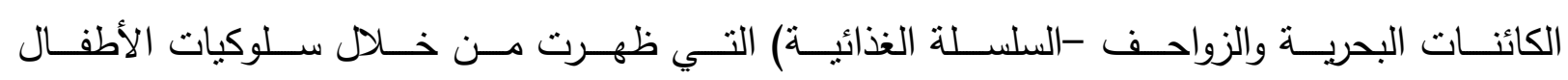
المرتبطــة بالمفــاهيم البيولوجيـة مـن حيـث أسـئلة الأطفـال واسـتجاباتهم حـول معرفــة خصـائص الكـائن

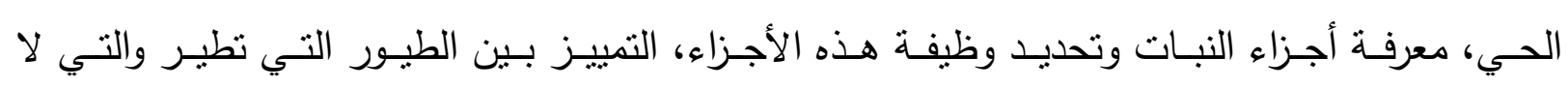

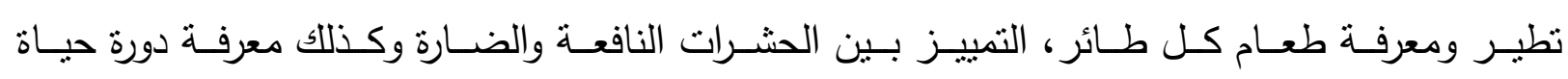

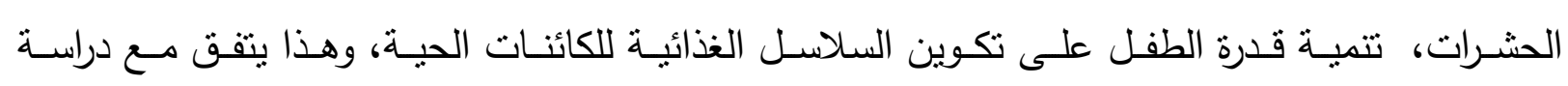

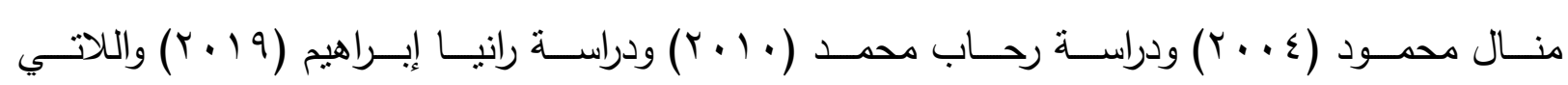

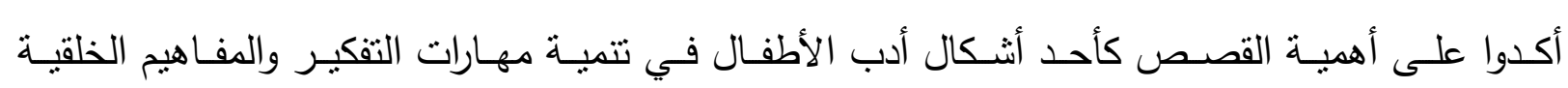
والإجنماعية والحقائق العلمية لطفل الروضة. وتخلص الباحثة مما سبق إلى تحقق صحة الفرض الثالث

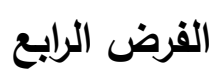

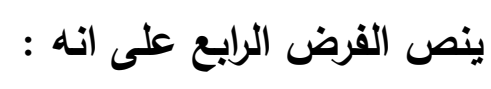

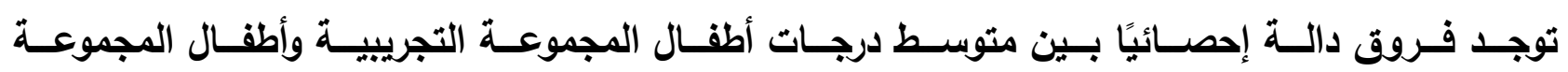

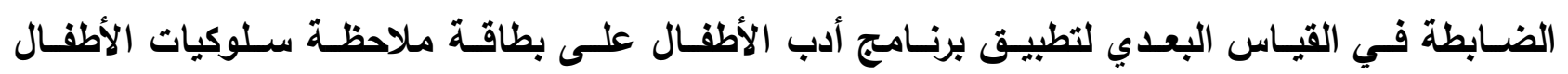
حول المفاهيم البيولوجية لصالح المجموعة التجريبية.

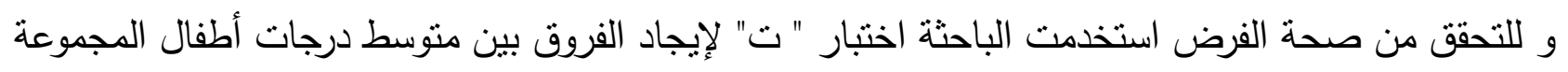

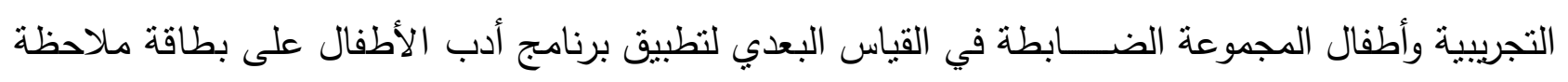
سلوكيات الأطفال حول المفاهيم كما يتضح فى جدول (rr) 


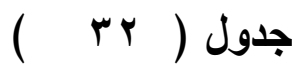

الفروق بين متوسط درجات أطفال المجموعة التجريبية وأطفال المجموعة الضابطة، في القياس البعدي

لتطبيق برنامج أدب الأطفال على بطاقة ملاحظة سلوكيات الأطفال حول الدفاهيم البيولوجية

$$
\text { ن. }
$$

\begin{tabular}{|c|c|c|c|c|c|c|c|c|c|}
\hline \multirow[t]{2}{*}{ حجم الأثر } & \multirow[t]{2}{*}{ مربع ايتا } & \multirow[t]{2}{*}{ |تجاه الدلالة | } & \multirow[t]{2}{*}{ مستوى الالالة } & \multirow[t]{2}{*}{ ت } & \multicolumn{2}{|c|}{ الضابطة المجة } & \multicolumn{2}{|c|}{ التجريبية } & \multirow[t]{2}{*}{ المتغيرات } \\
\hline & & & & & $r \varepsilon$ & $r^{\beta}$ & I & ما & \\
\hline كبير & $\cdot, 99$ & التجريبية & دالة عند مستوى & $7 ., .9$ & $\cdot, \varepsilon r$ & $0, r$ & $\cdot, \mathrm{Vr}$ & $1 \varepsilon, 0 r$ & الإنسان \\
\hline كبيز & $\cdot, 99$ & التجريبية & دالة عند مستوى & $7 \cdot, 9$ & $\cdot, 0$ & 0,0 & י, & $1 \leq, 0$ & النبات \\
\hline كبيز &., 99 & التجريبية & دالة عند مستوى & $74,1 Y$ & $\cdot, \leqslant V$ & $\theta, r r$ & $\cdot, 7$ & $1 \varepsilon, 79$ & الطيور \\
\hline كبيز &., 99 & التجريبية & دالة عند مستوى & $V V, T V$ & $\cdot, r \leq$ & 0,14 &., 04 & $1 \leqslant, 07$ & الحشرات \\
\hline كبيز & $\cdot, 99$ & التجريبية & دالة عند مستوى & $v 1, \& 1$ & $\cdot, r \varepsilon$ & 0,14 & י, & $1 \leqslant, 0$ & والزائنات البحرية \\
\hline كبير & $\cdot, 99$ & التجريبية & دالة عند مستوى & $70, \leqslant 9$ & $\cdot r v$ & 0,17 & $\cdot, 7 \wedge$ & $1 \leq, 0$ & السلسلة الغذائية \\
\hline كبير &., 99 & التجريبية & دالة عند مستوى & $17 r, r V$ & $\cdot, 9 \mathrm{~V}$ & $r_{1,0}$ & 1,09 & $\overline{~ A V, Y q}$ & الارجة الكلية \\
\hline
\end{tabular}

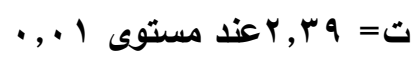

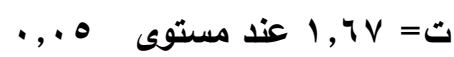

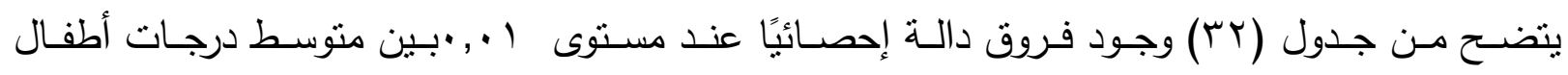

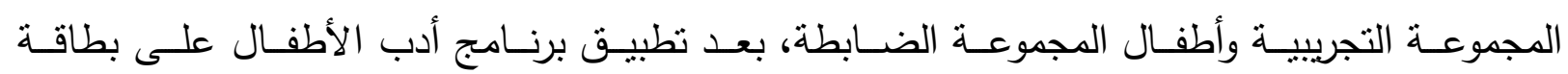
ملاحظة سلوكيات الأطفال حول المفاهيم لصالح المجموعة التجريبية.

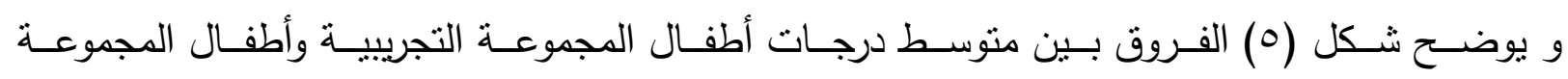

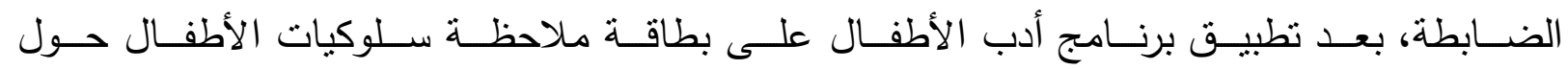

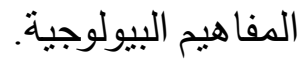




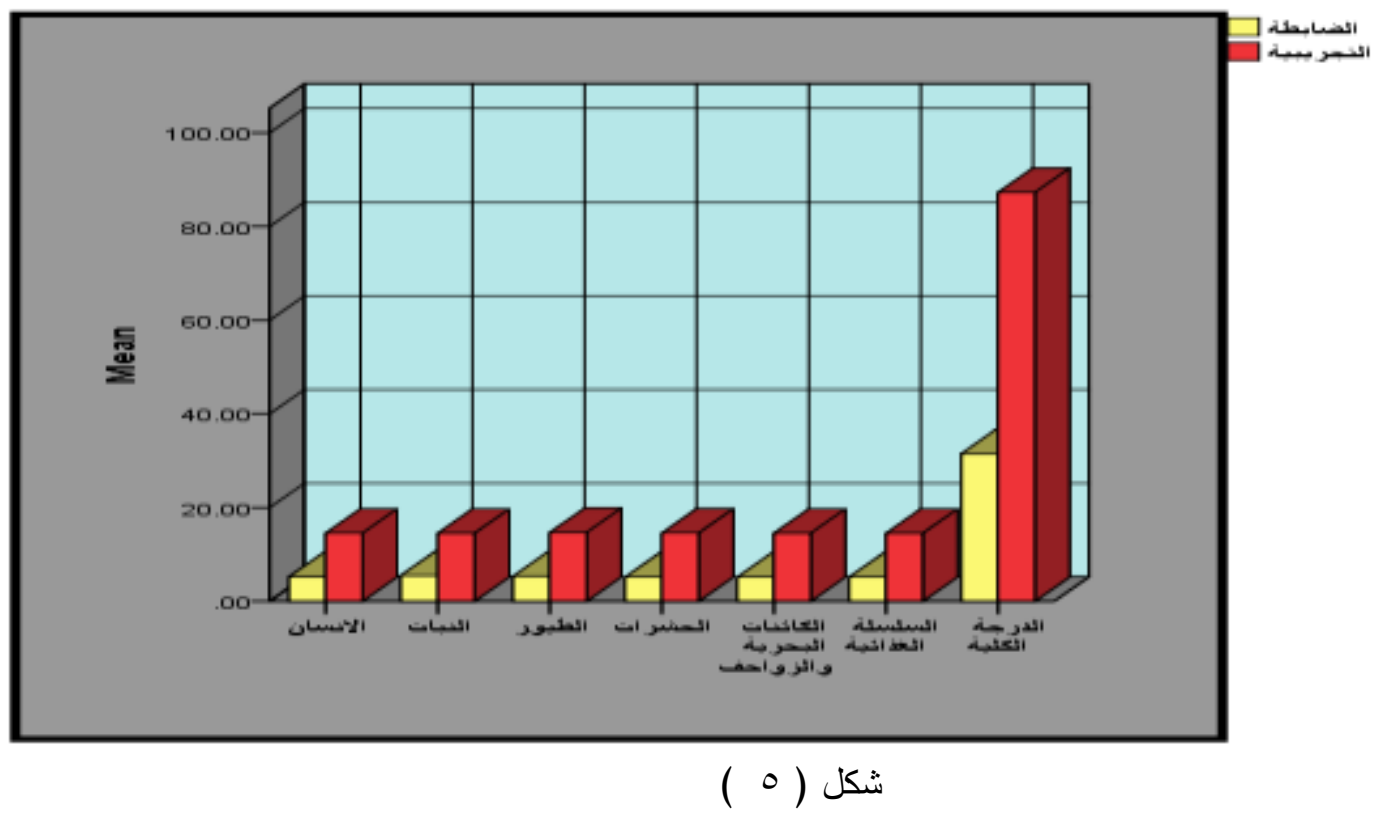

الفروق بين متوسط درجات أطفال المجموعة النجريبية وأطفال المجموعة الضابطة، بعد تطبيق برنامج أدب الأطفال على الطي

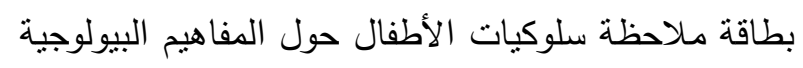

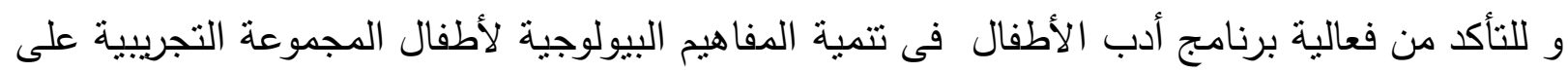

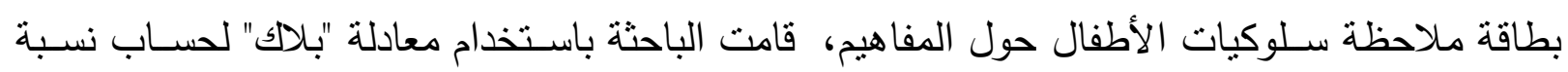
الكسب المعدل (Blake Gain Ratio) كما يتضح فى جدول (rr)

$$
\text { جدول (rr) }
$$

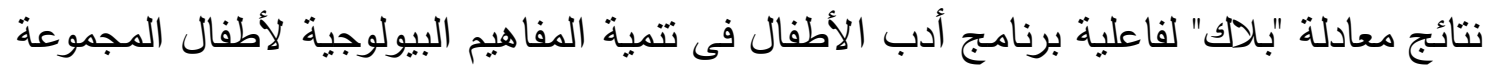

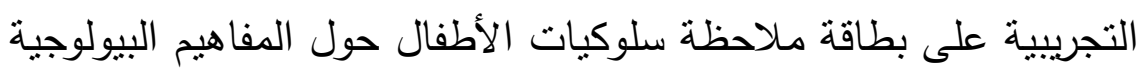

\begin{tabular}{|c|c|c|c|c|c|}
\hline الالالة & نسبة الكسب & النهاية العظمى & المتوسط & المجموعة & المتغيرات \\
\hline \multirow[t]{2}{*}{ ذات فاعلية } & \multirow[t]{2}{*}{$1,0 \mathrm{~V}$} & \multirow[t]{2}{*}{10} & $1 \leq, 0 Y$ & التجريبية & \multirow[t]{2}{*}{ الإنسان } \\
\hline & & & $0, Y r$ & الضابطة & \\
\hline \multirow[t]{2}{*}{ ذذات فاعلية } & \multirow[t]{2}{*}{$1,0 \leq$} & \multirow[t]{2}{*}{10} & $1 \leqslant, 0$ & التجرييية & \multirow[t]{2}{*}{ النبات } \\
\hline & & & 0,0 & الضابطة & \\
\hline \multirow[t]{2}{*}{ ذات فاعلية } & \multirow[t]{2}{*}{1,01} & \multirow[t]{2}{*}{10} & $1 \leq, 77$ & التجريبية & \multirow[t]{2}{*}{ الطيور } \\
\hline & & & $0, r r$ & الضابطة & \\
\hline \multirow[t]{2}{*}{ ذات فاعلية } & \multirow[t]{2}{*}{1,01} & \multirow[t]{2}{*}{10} & $1 \&, 07$ & التجريبية & \multirow[t]{2}{*}{ الحشرات } \\
\hline & & & 0,14 & الضابطة & \\
\hline \multirow[t]{2}{*}{ ذات فاعلية } & \multirow[t]{2}{*}{$1,0 \mathrm{~V}$} & \multirow[t]{2}{*}{10} & $1 \leqslant, 0$ & التجريبية & \multirow{2}{*}{ والزائنات البحرية } \\
\hline & & & 0,11 & الضابطة & \\
\hline \multirow[t]{2}{*}{ ذذات فاعلية } & \multirow[t]{2}{*}{$1,0 \mathrm{~V}$} & \multirow[t]{2}{*}{10} & $1 \leqslant, 0$ & التجريبية & \multirow[t]{2}{*}{ السلسلة الغذائية } \\
\hline & & & 0,17 & الضابطة & \\
\hline \multirow[t]{2}{*}{ ذات فاعلية } & \multirow{2}{*}{$1,0 \mathrm{~V}$} & \multirow{2}{*}{9.} & $\Lambda \mathrm{AV,Yq}$ & التجريبية & \multirow[t]{2}{*}{ الارجة الكلية } \\
\hline & & & $r_{1}, 0$ & الضابطة & \\
\hline
\end{tabular}




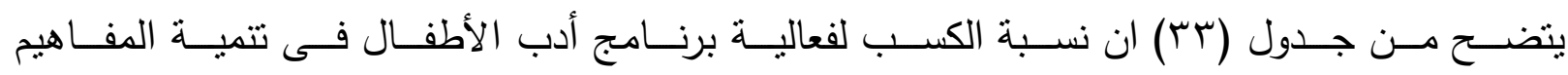

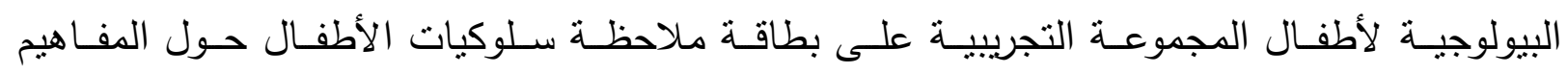

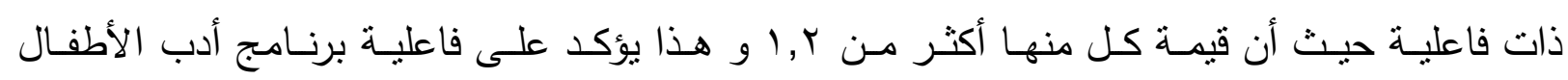

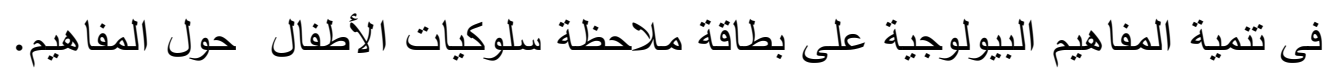
وتعزو الباحثة تفوق أطفال المجموعة التجريبية على أبعاد بطاقة الملاحظة حول المفاهيم البيولوجية البطات

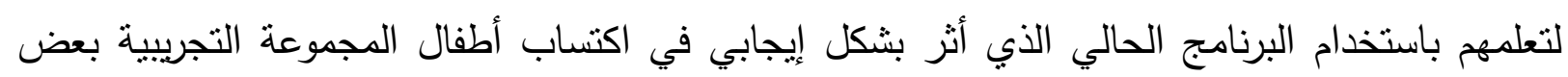

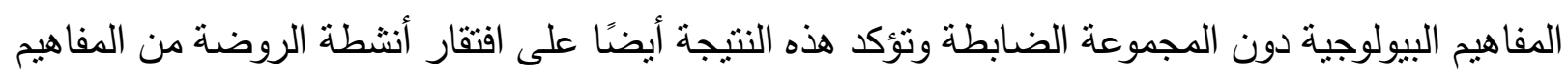
البيولوجية حيث أن المجموعة الضابطة التي تتعرض لبرنامج الروضة التقليدي جاء نتائجها غير دالة إحصائيًا

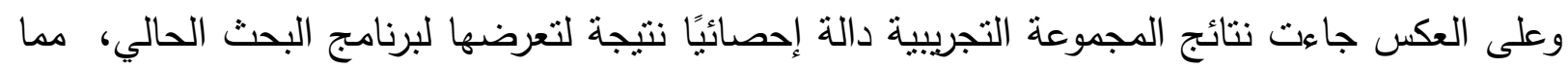

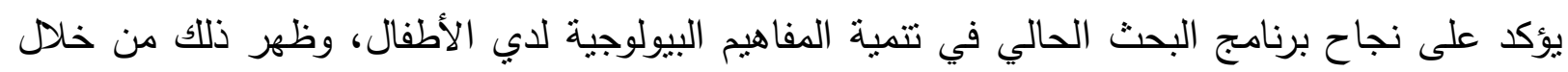
أسئلة الأطفال واستجاباتهم حول المفاهيم التي تعلمونها وربطها بحياتهم، وتذكر الباحثة أن الطفلة (م. م)

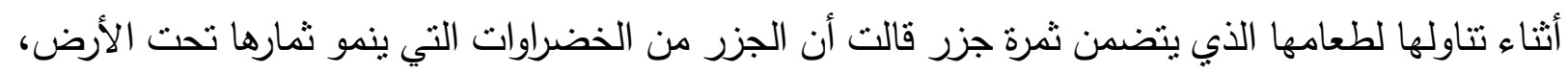

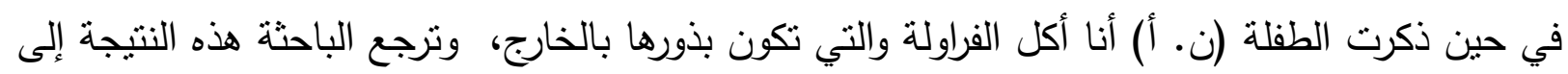

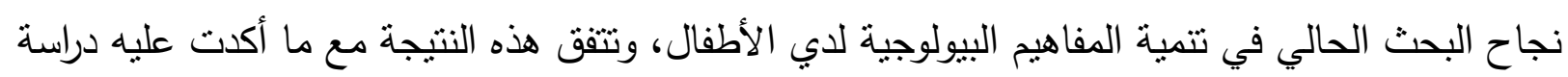

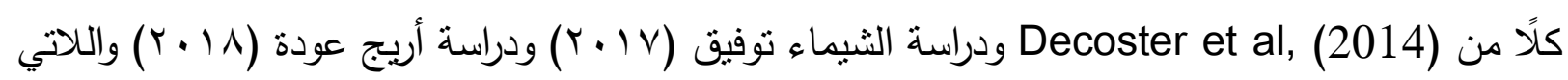
أكدوا جميعًا على أهمية تتمية المفاهيم البيولوجية لطفل الروضية.

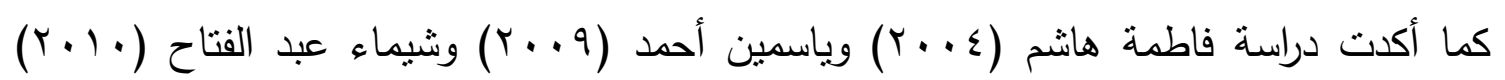

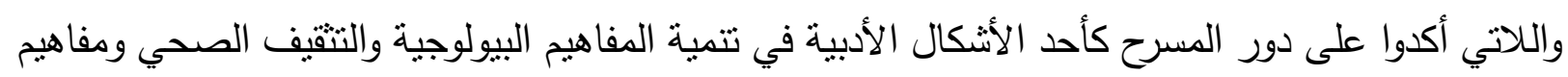
الظواهر الطبيعية لدي طفل الروضة. كما تعزو الباحثة تقوق أطفال المجموعة التجريبية على أبعاد بطاقة الملاحظة حول المفاهيم

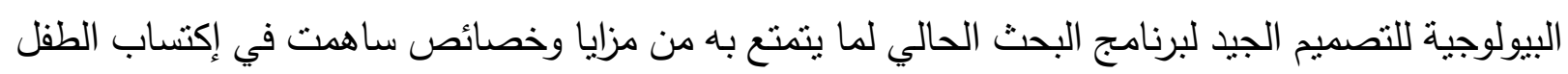

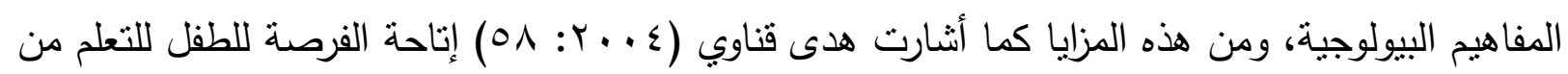

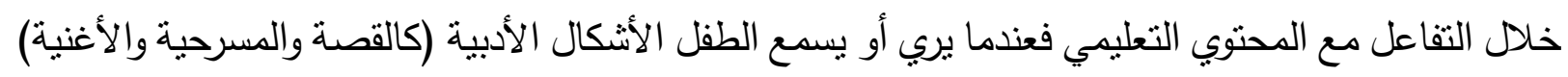

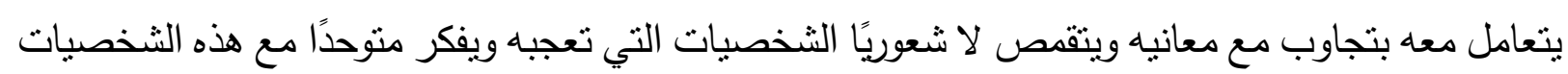

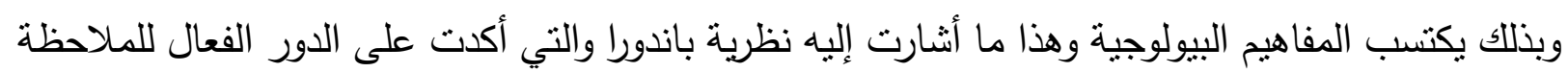
والنماذج والقدوة في تعلم الطفل. كما ترجع الباحثة عدم تفوق أطفال المجموعة الضابطة لاعتمادها على إسلوب التعلم التقليدي

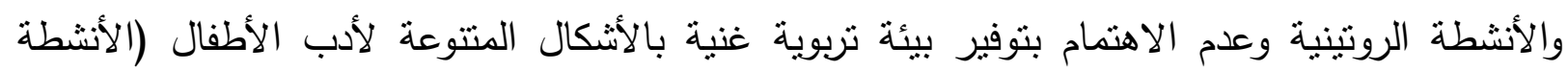

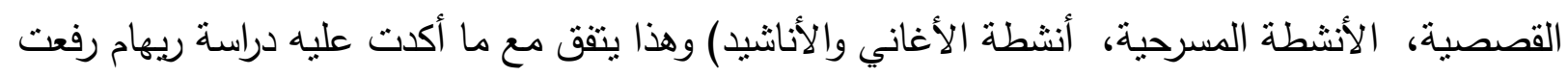

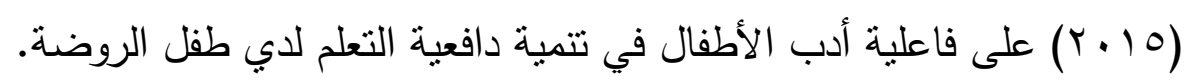


وتخلص الباحثة مما سبق إلى تحقق صحة الفرض الرابع

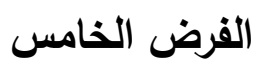
ينص الفرض الخامس على انه :

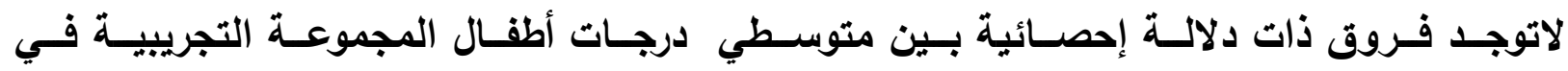

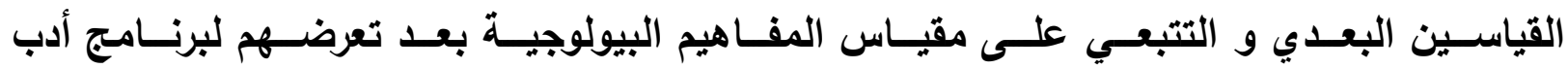
الأطفال . الإليزن

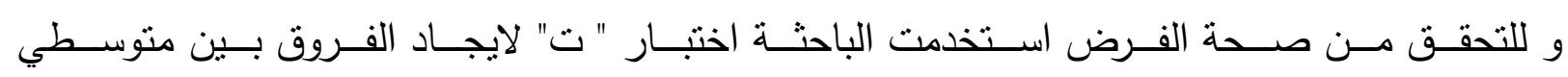

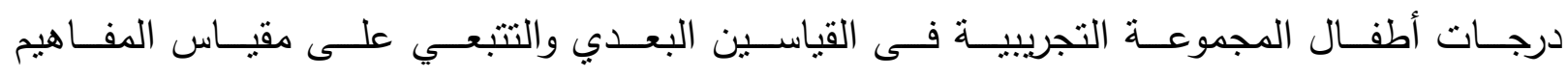

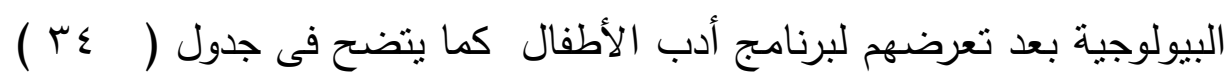

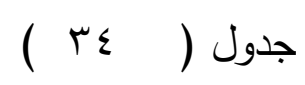

الفروق بين متوسطي درجات أطفال المجموعة التجريبية فى القياسين البعدي و التتبعي على مقياس المفاهيم البيولوجية بعد تعرضهم لبرنامج أدب الأطفال

$$
r \cdot=\dot{~}
$$

\begin{tabular}{|c|c|c|c|c|c|}
\hline \multirow[t]{2}{*}{ اتجاه الدلالة } & \multirow[t]{2}{*}{ مستوى الالاد } & \multirow[t]{2}{*}{ ت } & \multicolumn{2}{|c|}{ القياسين البعدي و الفرق بين } & \multirow[t]{2}{*}{ المتغيرات } \\
\hline & & & مج حف & 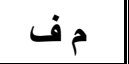 & \\
\hline - & غير دالة & $1, \varepsilon \mu q$ & , ror & $\mid, ., 77$ & الإنسان \\
\hline- & غير دالة & 1 & . IAr & $\cdot, \cdot r T$ & النبات \\
\hline - & غير دالة & 1 & , r40 & •, . 47 & الطيور \\
\hline - & غير دالة & $1, \varepsilon \% q$ & , ror & $\mid, ., 74$ & الحشرات \\
\hline - & غير دالة & 1 &.,$I \Lambda Y$ & D & الكائنات البحرية والزواحف \\
\hline- & غير دالة & 1 & . IAr & $\cdot, \cdot r T$ & السلسلة الغذائية \\
\hline- & غير دالة & -,$\leqslant \Psi Y$ & $1, Y 71$ &., 1 & الارجة الكلية \\
\hline
\end{tabular}

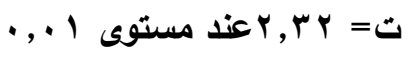

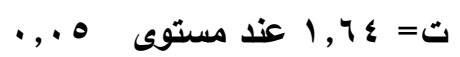

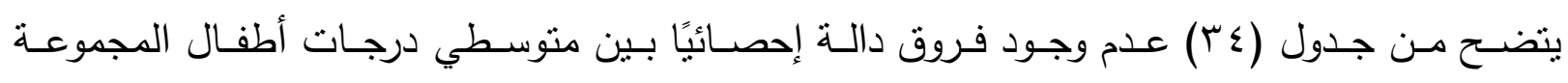

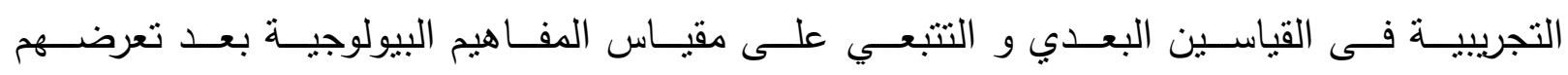

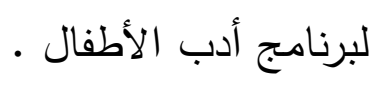
وتتثير النتائج إلى استمرارية فاعلية برنامج أدب الأطفال بعد مدة التجريب مما يؤكد الأثر الإيجابي

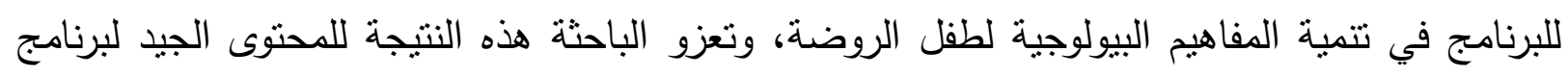

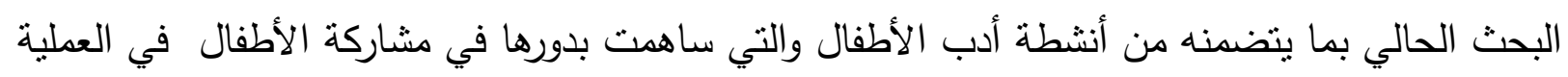

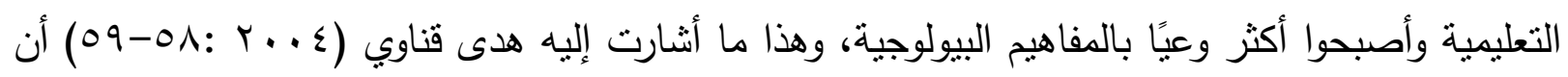


أدب الأطفال هو خير معلم؛ حيث يقدم من خلاله نماذج مختلفة ومواقف حياتية منتوعة تساعد الطفل في

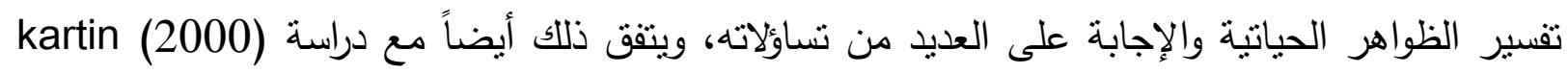

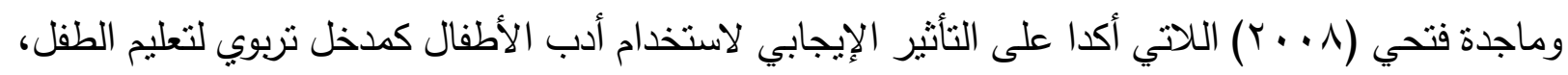

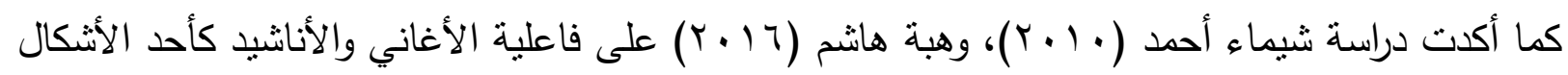

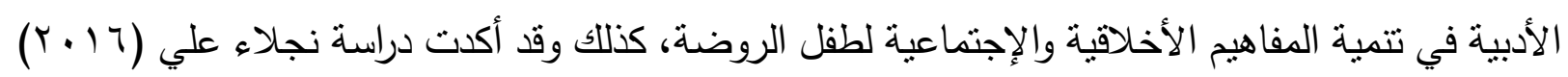

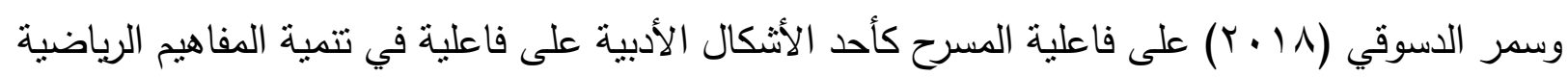
بالإضافة لتتمية بعض جوانب الثخصية والإحساس بالمسئولية لدي طفل الروضة الثية. وتخلص الباحثة مما سبق إلى تحقق صحة الفرض الخامس.

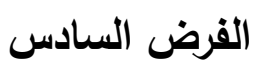
ينص الفرض السادس على أنه :

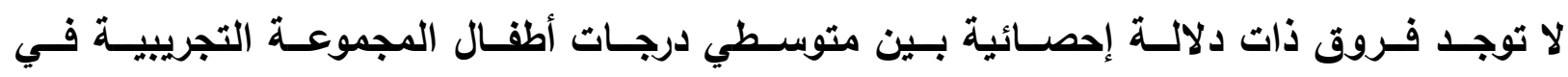

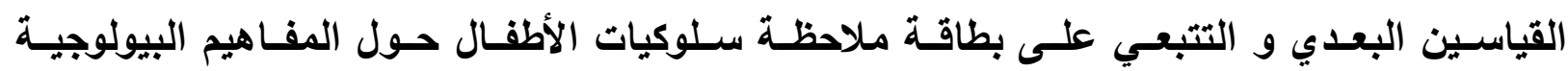

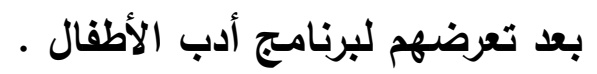

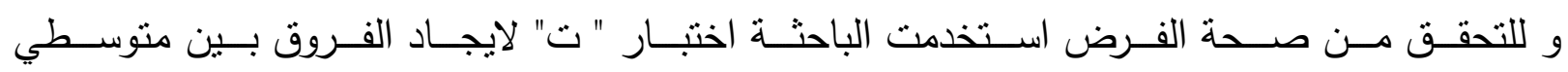

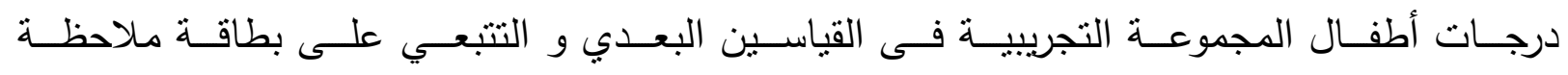

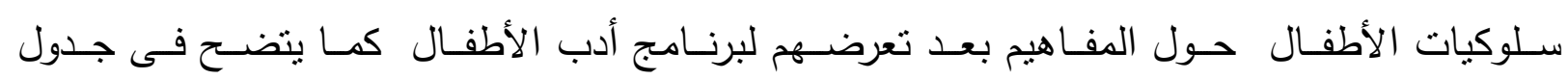

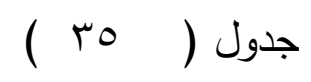

الفروق بين متوسطي درجات أطفال المجموعة التجريبية فى القياسين البعدي و التبعي على الثيلى بطاقة

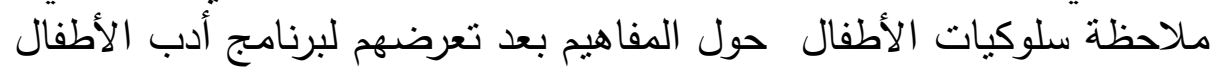

\begin{tabular}{|c|c|c|c|c|c|}
\hline \multirow[t]{2}{*}{ اتجاه الدلالة } & \multirow[t]{2}{*}{ مستوى الدلادة } & \multirow[t]{2}{*}{ 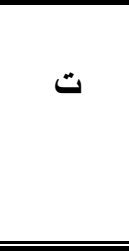 } & \multicolumn{2}{|c|}{ القياسين البعدي و الفروق } & \multirow[t]{2}{*}{ المتغيرات } \\
\hline & & & مج حف & م م م & \\
\hline- & غير دالة & 促, & ·, & $\cdot, \cdot,+4 T$ & الإنسان \\
\hline- & غير دالة & $1, \leqslant 4 q$ & . ror & 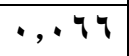 & النبات \\
\hline- & غير دالة & 1 & $\cdot, I \wedge r$ & 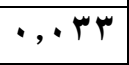 & الطيور \\
\hline- & غير دالة & - & - & - & الحشرات \\
\hline- & غير دالة & 1 & $\cdot, I \wedge r$ & 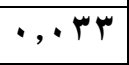 & الكائنات البحرية والزواحف \\
\hline- & غير دالة & $1, \pi 4$ & $\cdot, \varepsilon \cdot Y$ & 1 & السلسلة الغذائية \\
\hline - & غير دالة & $1, Y Y Y$ & $\cdot, \mathrm{V} \leq 4$ &., 174 & الارجة الكلية \\
\hline
\end{tabular}




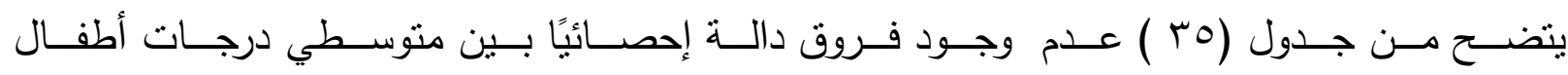

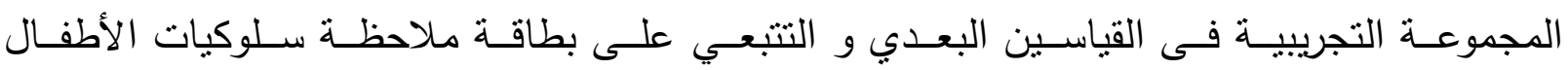

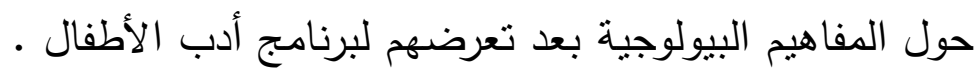

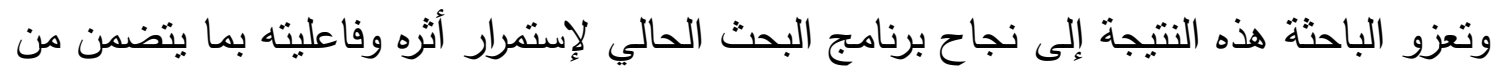

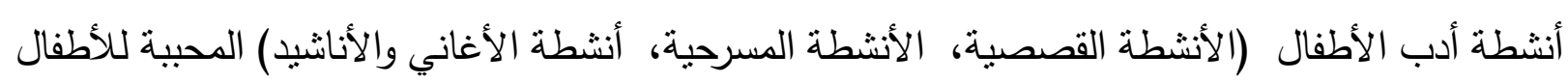

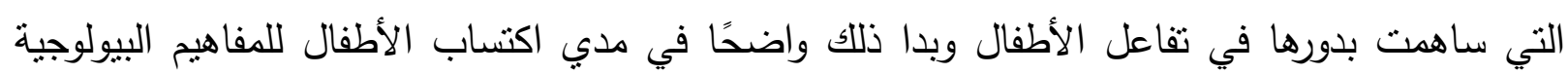

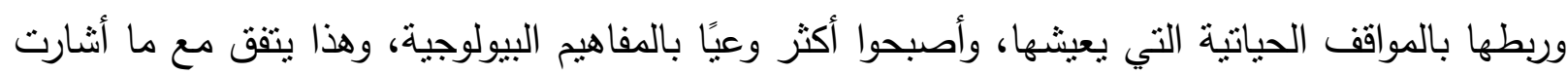

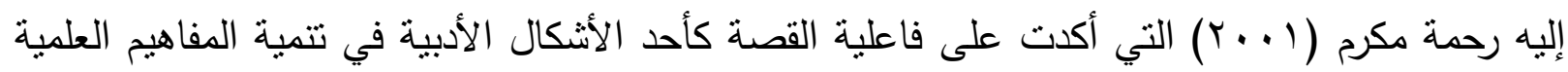

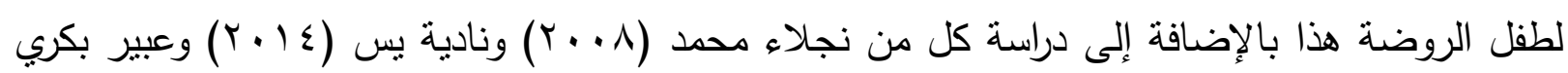

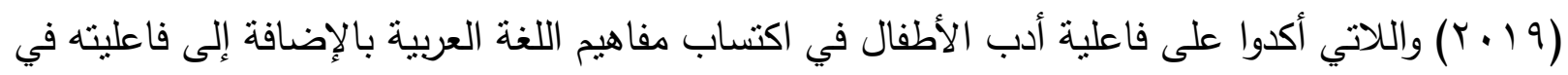

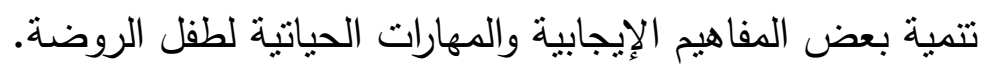

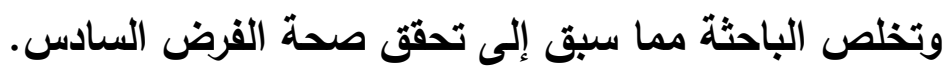

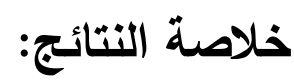
من خلال البحث تحققت جميع فروض البحث وكانت نتائج البحث كالآتي:

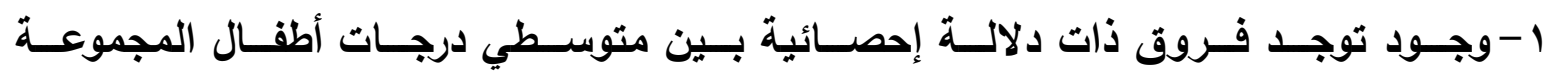

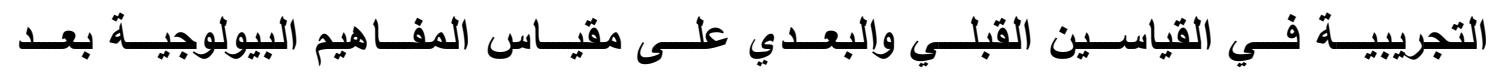

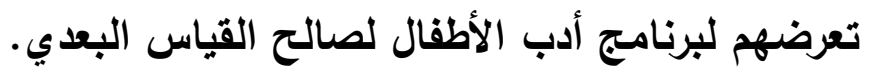

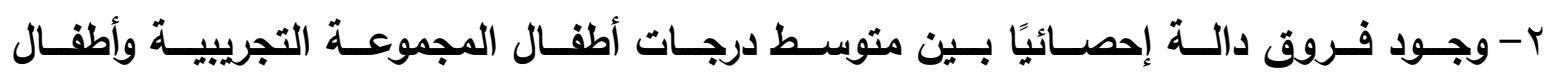

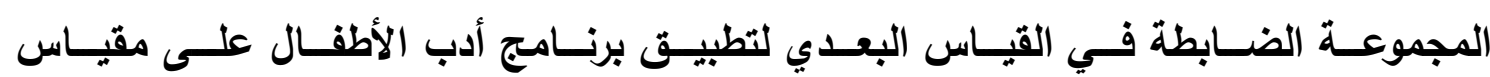
المفاهيم البيولوجية لصالح المجموعة التجريبية.

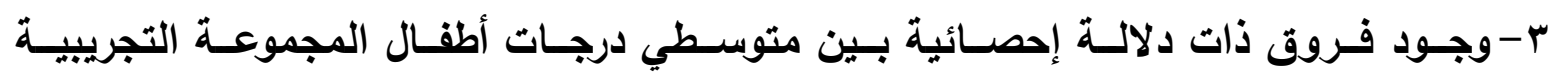

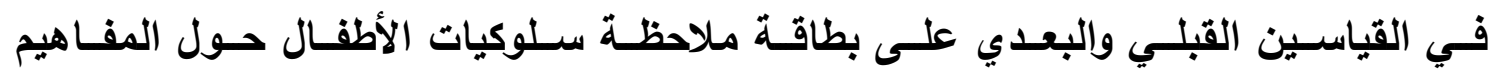

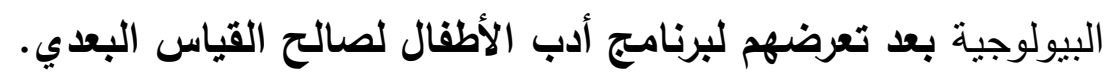

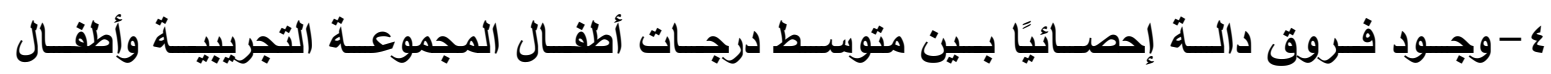

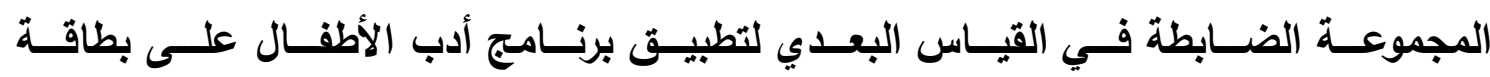

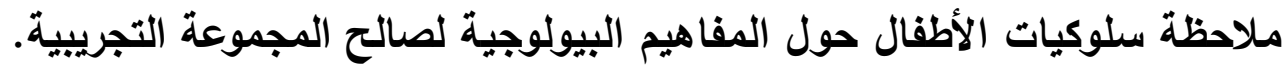

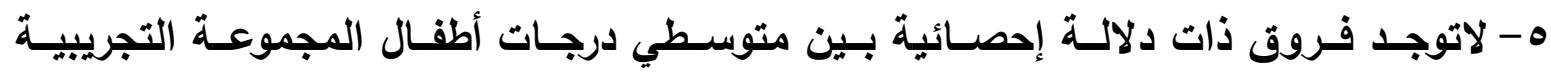

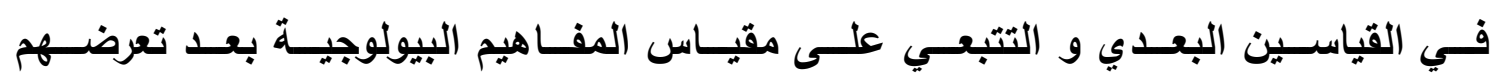

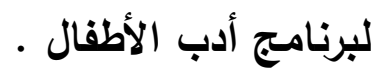

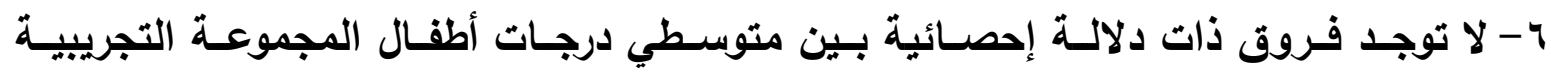

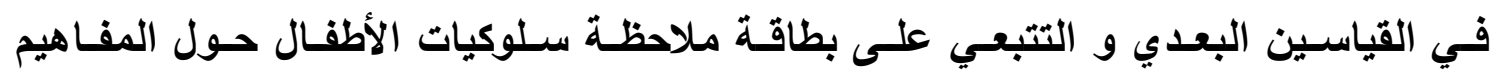

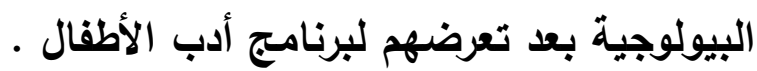




\section{توصيات البحث}

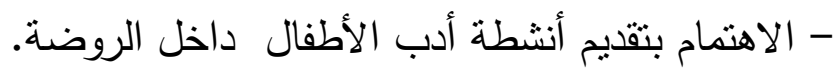

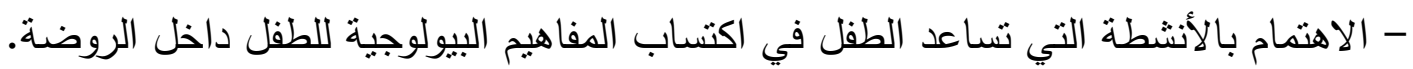

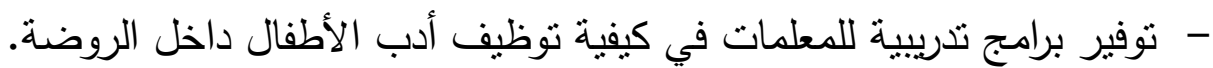

\section{البحوث المقترحة}

- فاعلية أدب الأطفال في تتمية مفهوم إدارة الذات لطفل الروضة. - فاعلية أدب الأطفال في تتمية بعض الدفاهيم الفيزيائية والكيميائية لطفل الروضة ذلوضية ذاري صعوبات

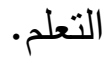

المراجع

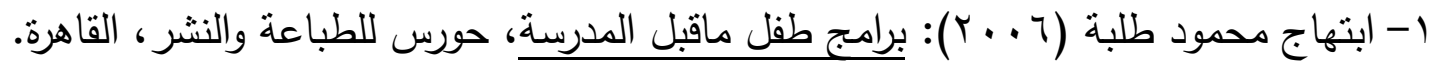

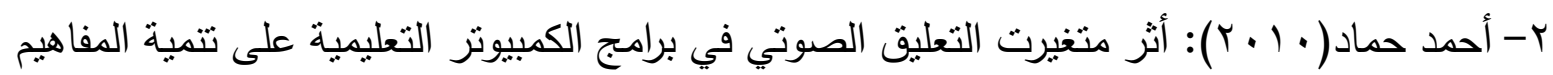

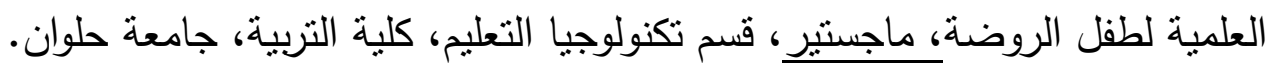

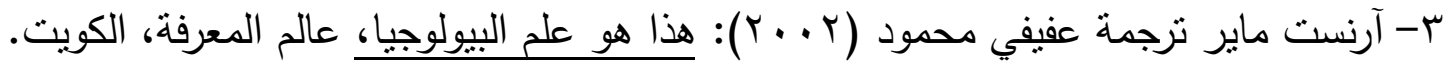

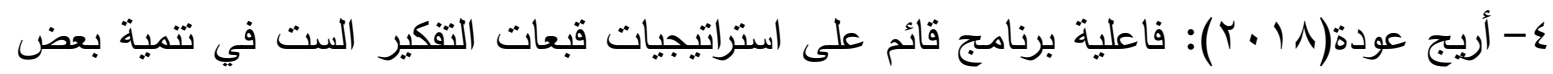

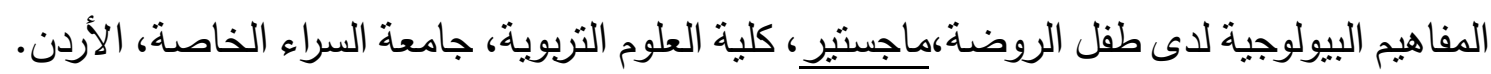

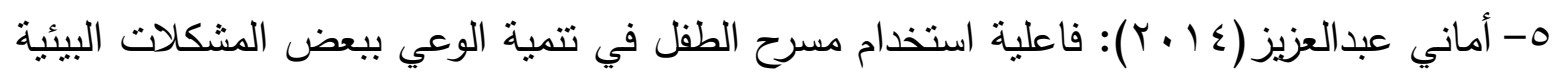

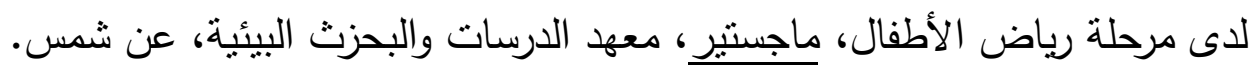

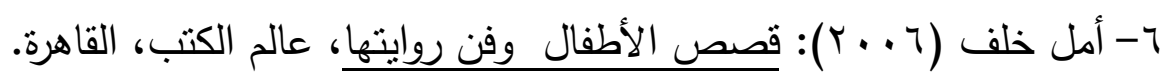

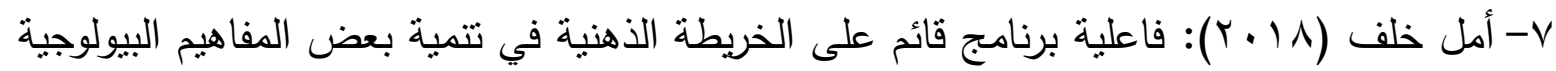

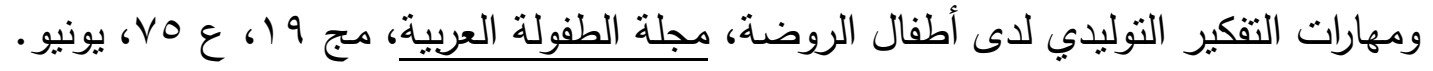

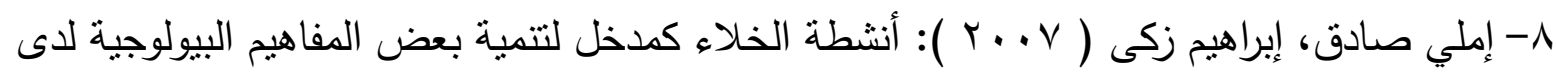

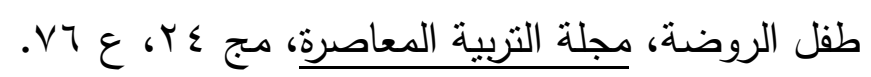

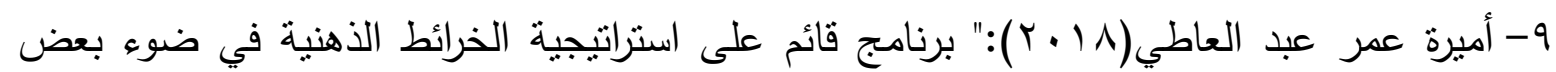

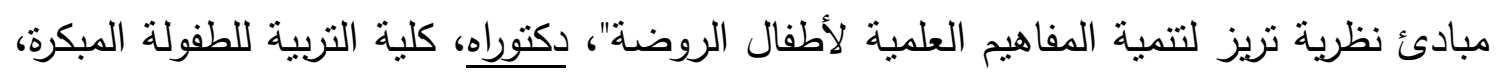

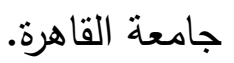
• 1- إيمان رفعت محمد طه (1) ب ب):" فاعليه استراتيجيه التعلم القائم على المشكله في اكتساب اطفال

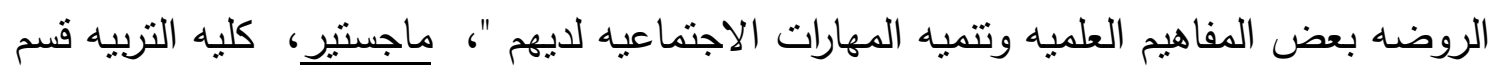
مناهج وطرق تدريس، جامعه حلوان.

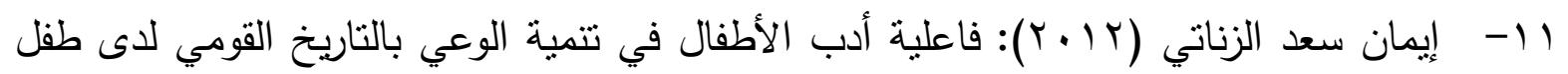

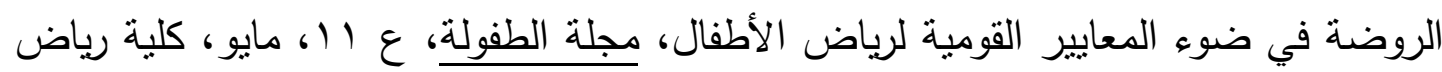
الأطفال، جامعة القاهرة. 
r ا-بر جمال محمد(ع ا ـ Y): فعالية برنامج مقترح لتتمية القيم البيئية السليمة لطفل الروضة باستخدام مسرح العرائس، ماجستير، كلية التربية، جامعة طنطا. r ا-بطرس حافظ بطرس (§ ( • r): تتمية المفاهيم والمهارات العلمية لأطفل ماقبل المدرسة، دار المسيرة للنشر والتوزيع، عمان، الأردن. ع ا-بطرس حافظ بطرس( (1 ـ ץ): تتمية المفاهيم العلمية والرياضية لطفل الروضية، دار المسيرة، عمان،

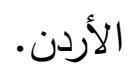
10- جبر الدين براين سيلكن ترجمة إميلي صادق ميخائيل (ب . - ب): الدراما والطفل، القاهرة، عالم الكتاب.

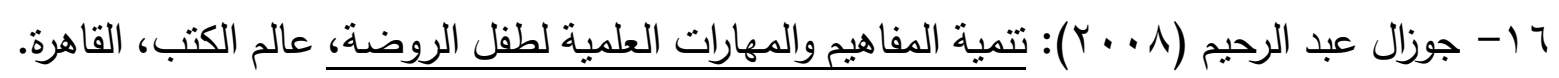

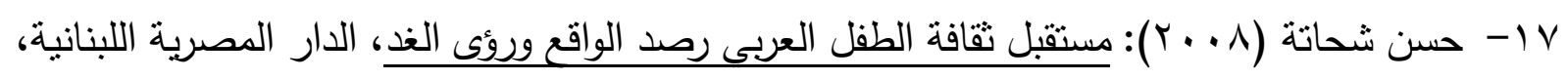
القاهرة .

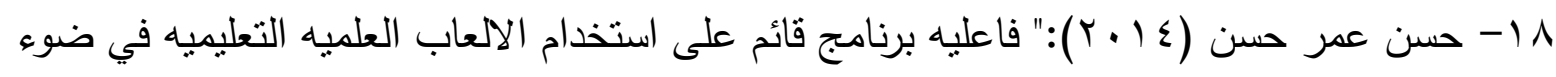

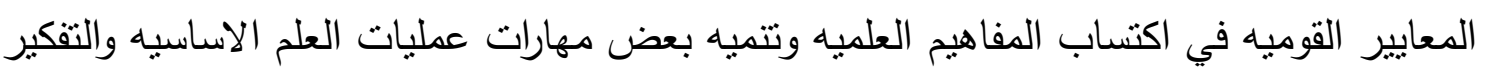

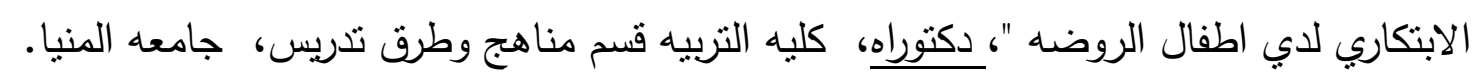

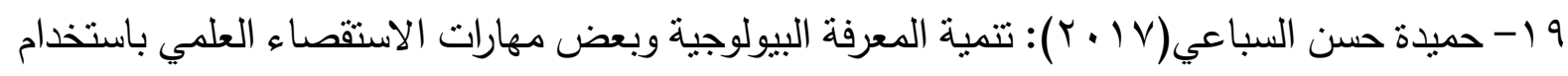

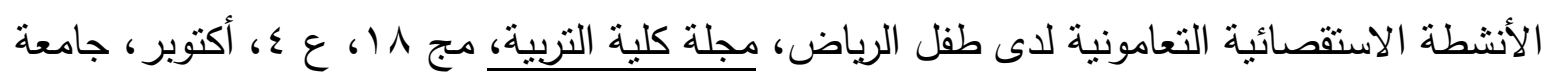
طنطا.

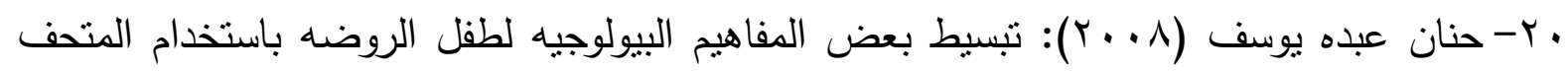

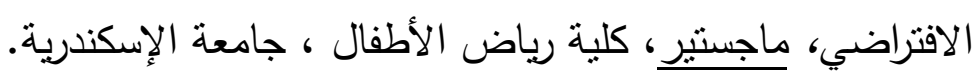

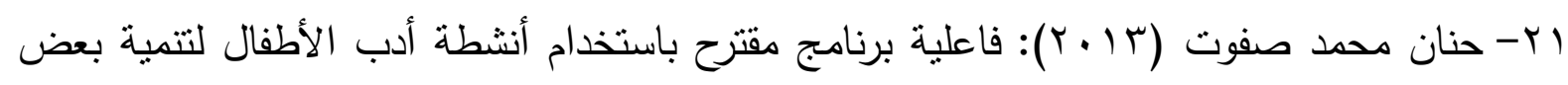

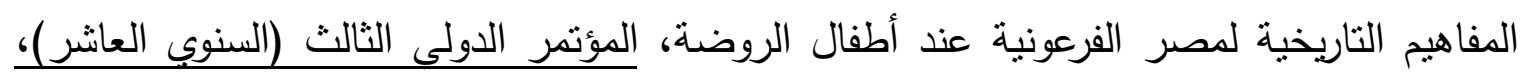
• بأبريل، كلية رياض الأطفال ، جامعة القاهرة.

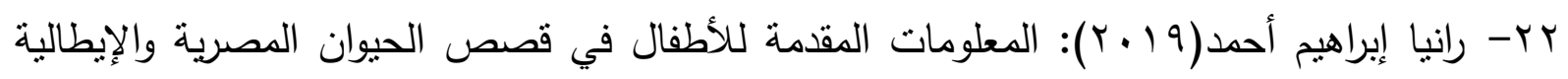

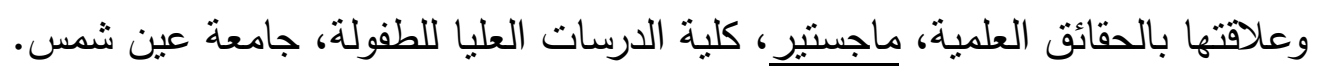

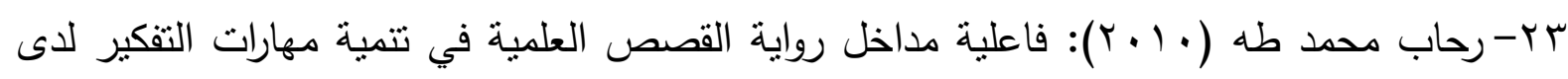
طفل الروضة، ماجستير، معهد الدرسات التربوية، جامعة القاهرة.

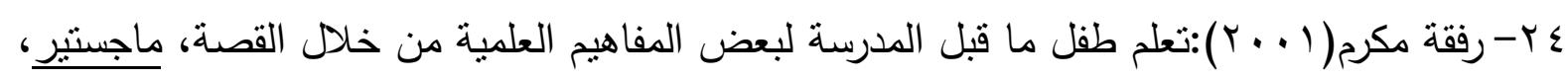
كلية التربية، جامعة حلوان.

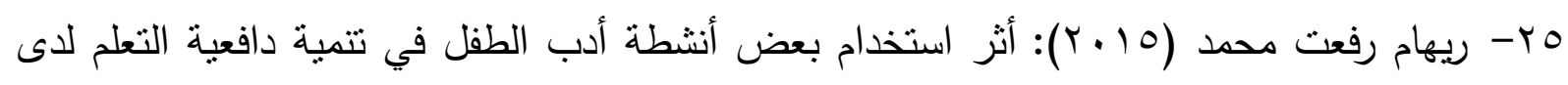

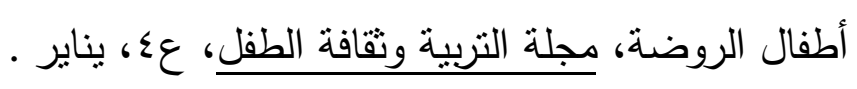
ج ץ-زكريا الثربيني، يسرية صادق ( . . ب): نمو المفاهيم العلمية للأطفال، دار الفكر العربى، القاهرة. 


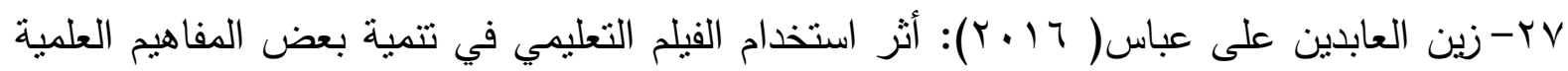

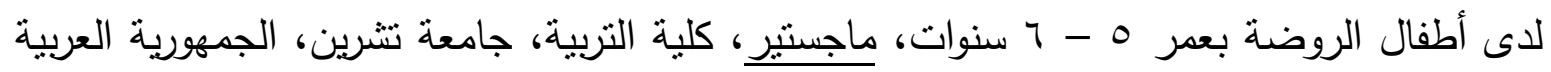

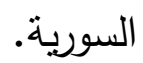

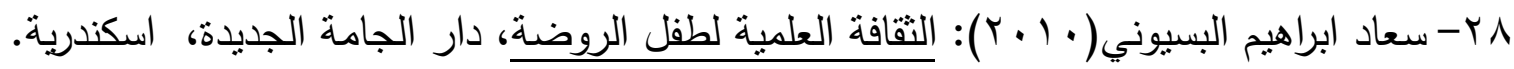

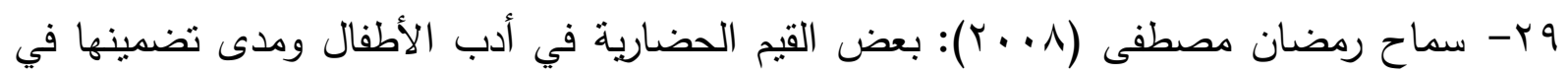
أنشطة رياض الأطفال الرسمية والخاصة "دراسة تحليلية مقارنة"، ماجستير، كلية التربية، جامعة الاطية

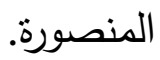

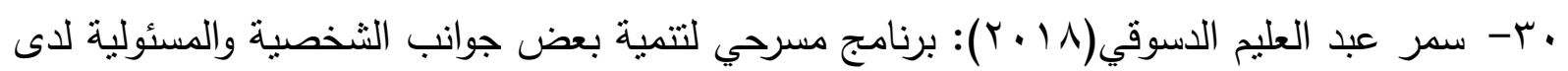
طفل الروضة، دكتوراه، كلية التربية للطفولة المبكرة، جامعة القاهرة. اسب-سمير عبدالوهاب أحمد (ع ( • ب): أدب الأطفال قراءات نظرية ونماذج تطبيقية، دار المسيرة للنشر والتوزيع، عمان.

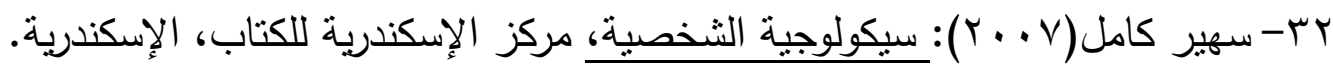

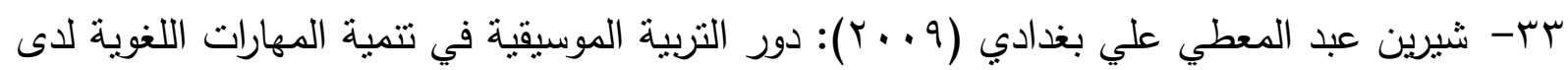

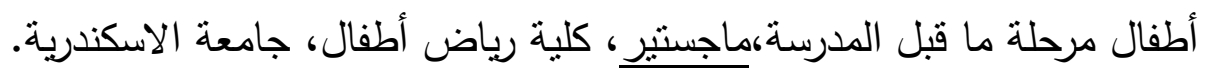

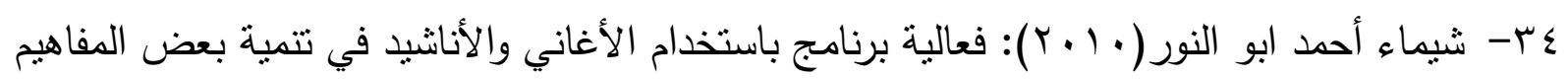

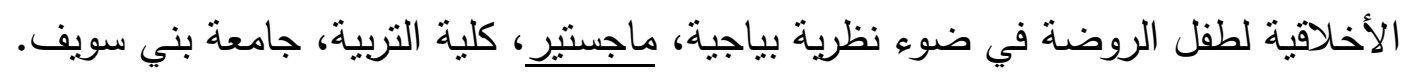

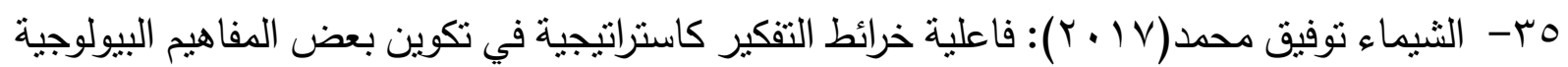
لاى طفل الروضة، ماجستير ، كلية البنات والعلوم والتربية، جامعة عين شمس.

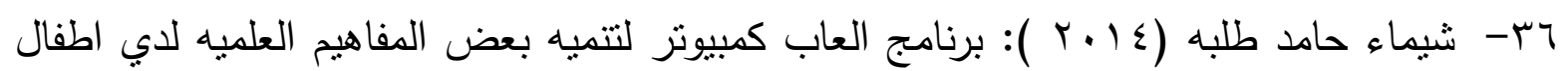

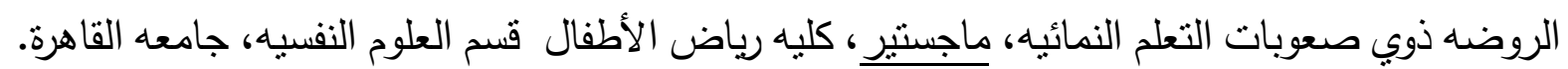

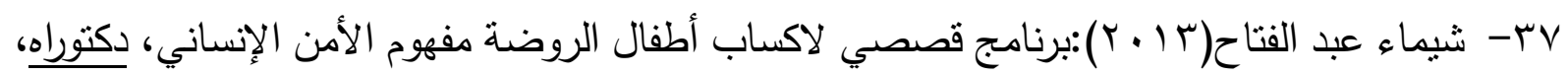
كلية رياض الأطفال ، جامعة القاهرة.

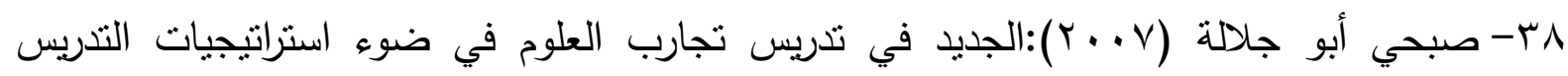
المعاصرة، مكتبة الفلاح للنشر والتوزيع، دولة الإمارات العربية المتحدة.

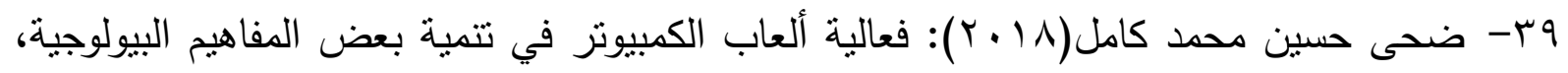
ماجستير ، كلية التربية للطفولة المبكرة، جامعة المنيا.

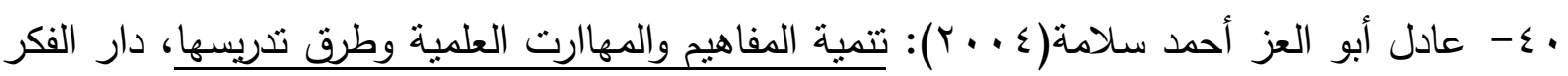

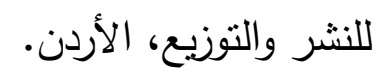

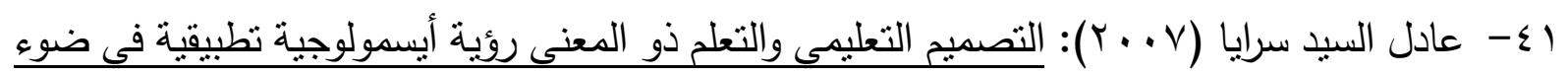
نظرية تجهيز المعلومات بالذاكرة البشرية، دار وائل للنشر، ،عمان، الأردن. 


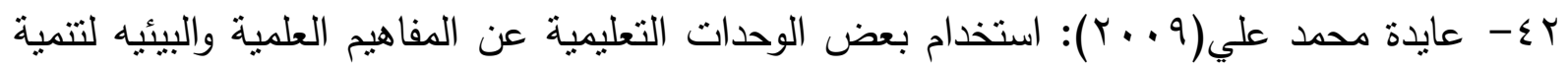

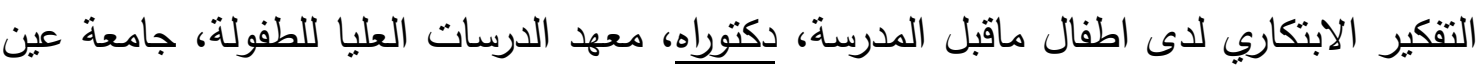
شمس.

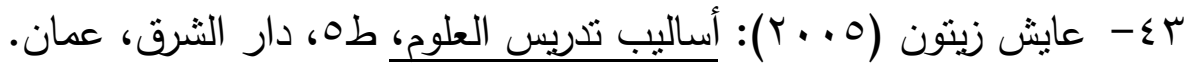

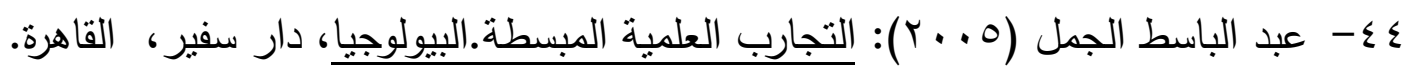

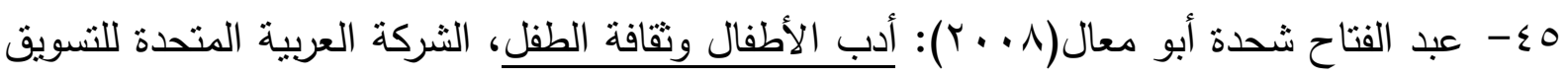
والتوريدات، القاهرة.

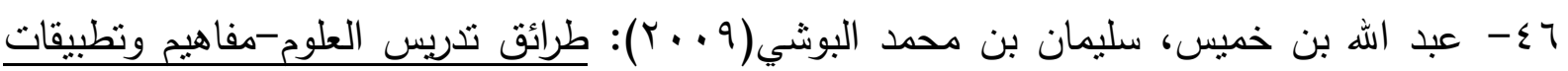
عملية، دار المسيرة، عمان، الأردن.

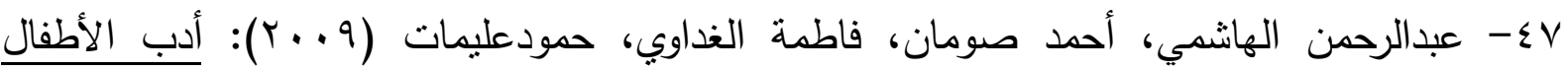

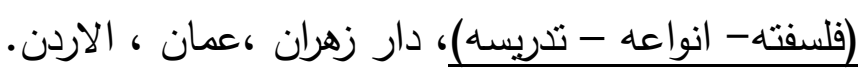

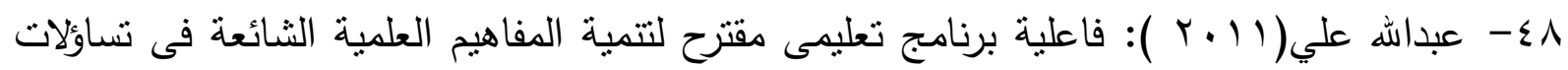

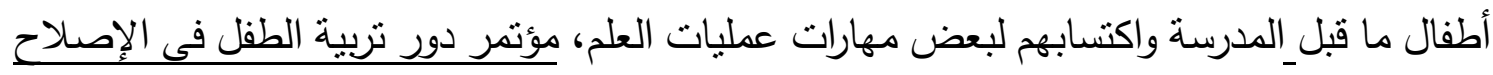

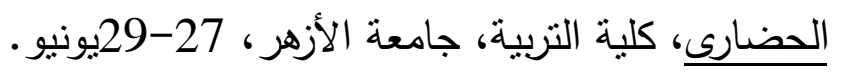

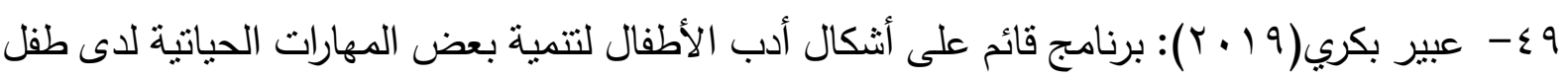

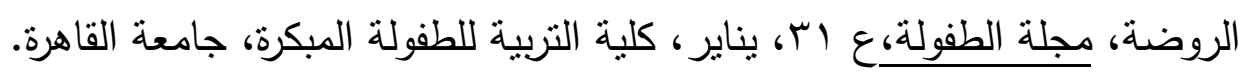

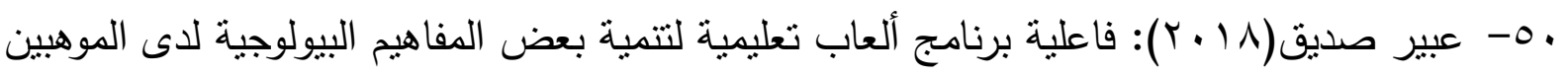

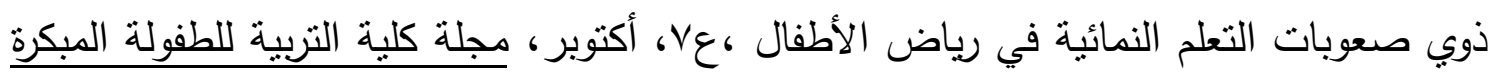
جامعة أسيوط.

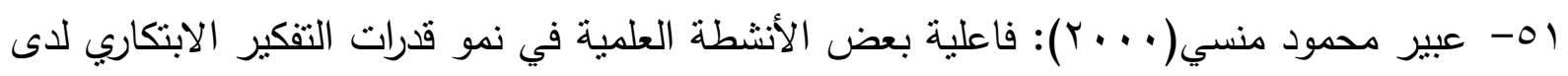

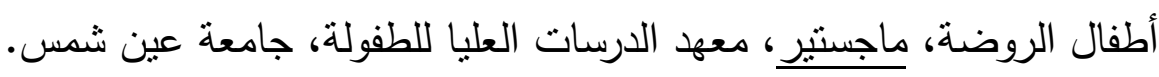

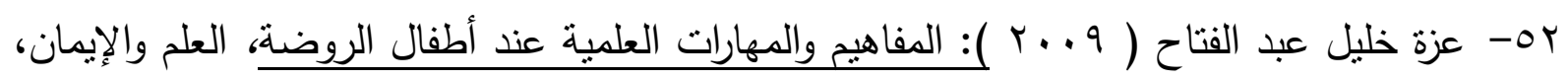
كفر الثيخ.

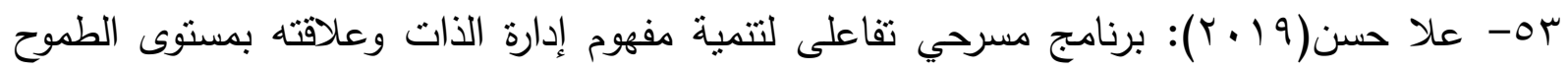

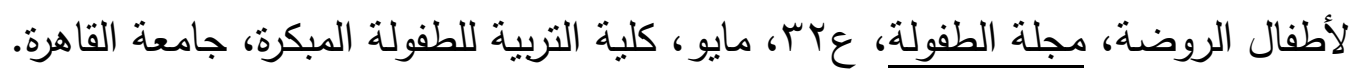

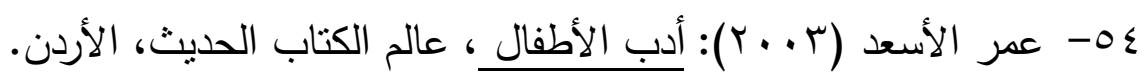

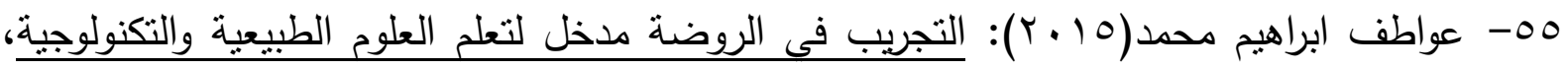
مكتبة الأنجلو المصرية، القاهرة.

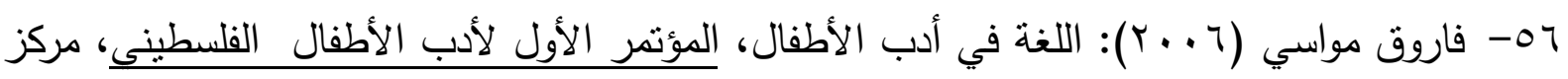

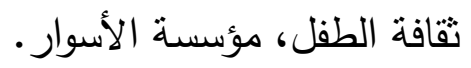

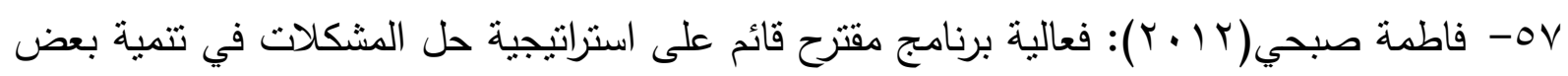
الدفاهيم العلمية لدى طفل الروضة، ماجستير، جامعة بنها. 


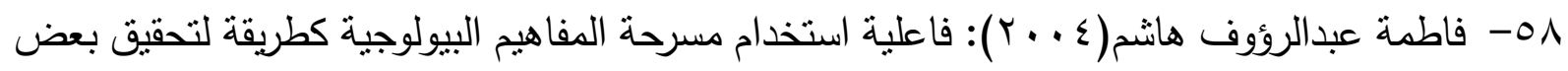

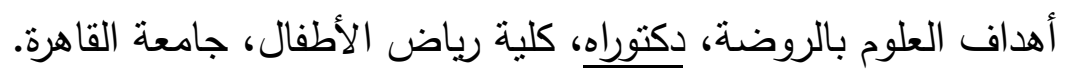

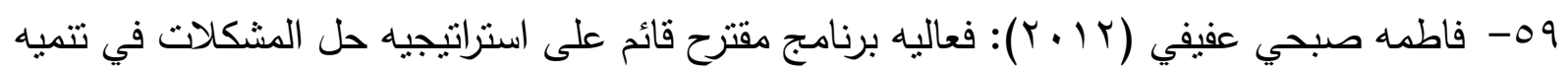

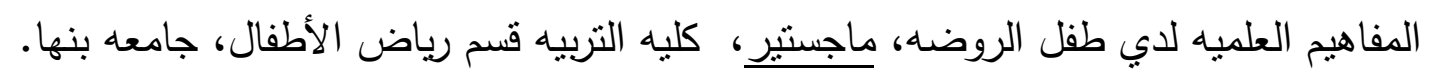

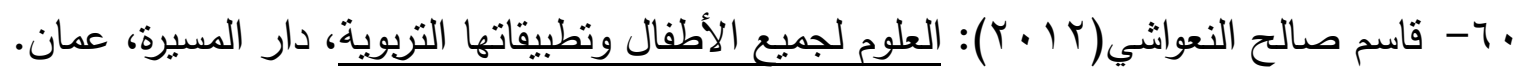

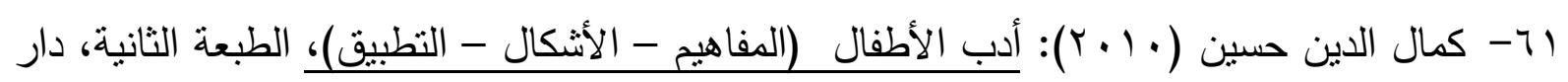

$$
\text { العالم العربي، القاهرة. }
$$

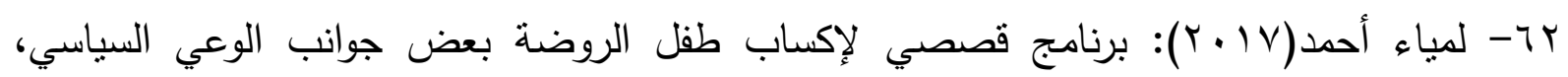

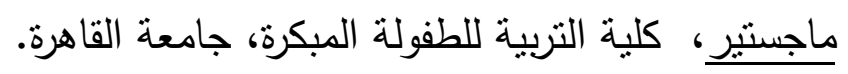

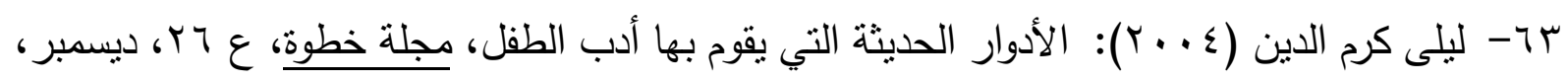
المجلس العبي للطفولة والتتمية. ع ؟- ماجد الجلاد( ( . ؟): تدريس التربية الإسلامية الأسس النظرية والأساليب العلمية، عمان، دار المسيرة.

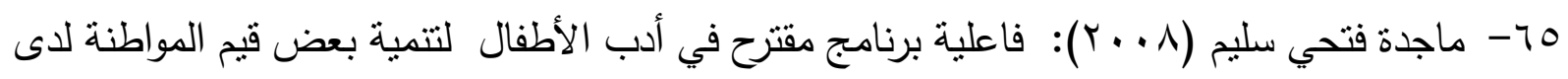

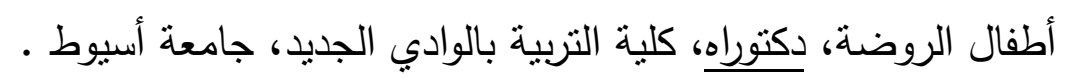

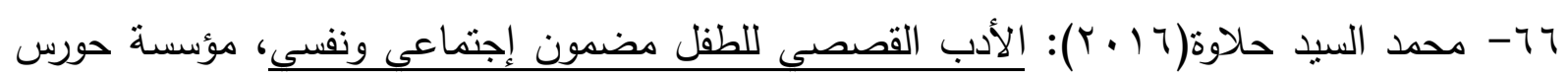
الدولية، الاسكندرية.

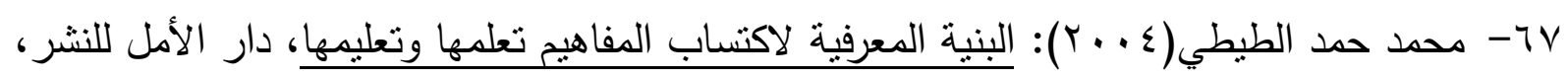
الأردن.

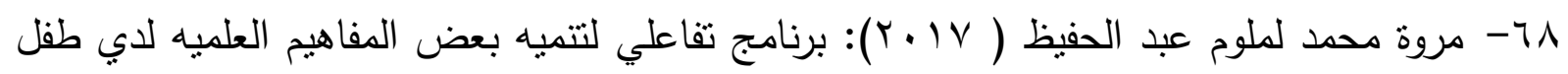

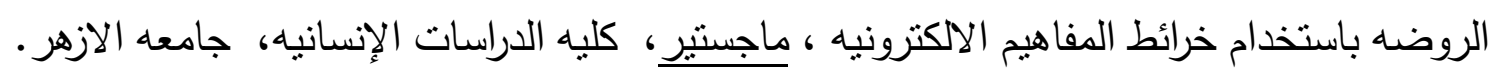

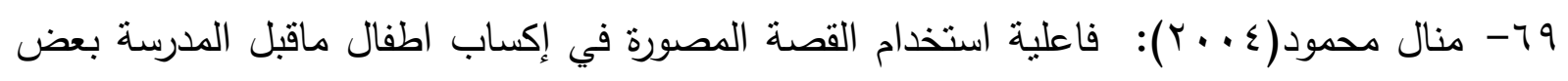

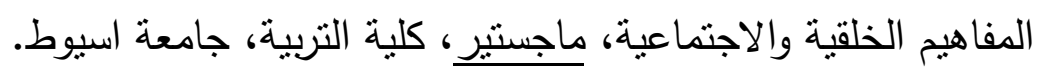

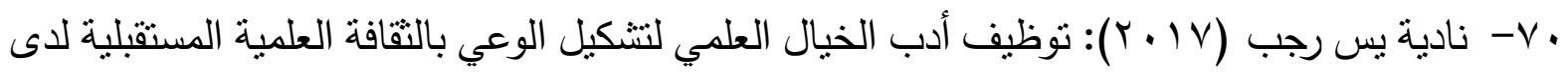

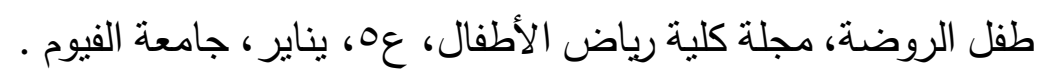

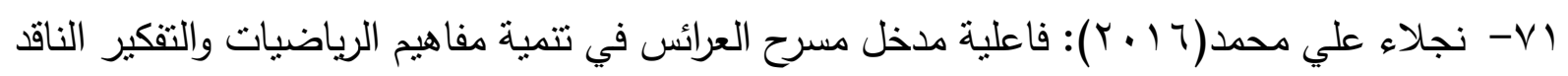
لطفل الروضة، دكتوراه، كلية التربية، جامعة عين شعس.

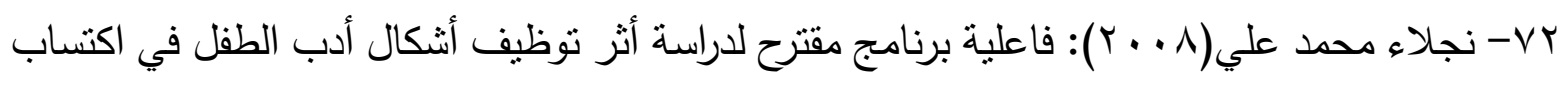

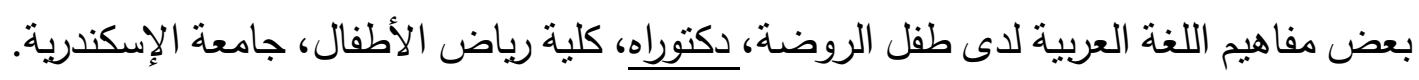

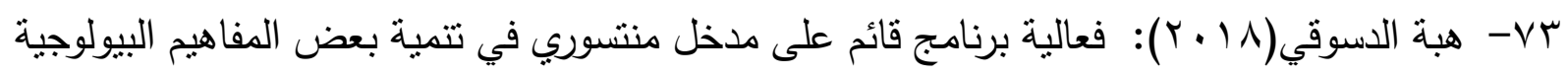
والميول العلمية لطفل الروضة، ماجستير، كلية التربية، جامعة قناة السويس. 
ع -V هبة هاشم محمد(T ( • Y): فاعلية برنامج مقترح باستخدام الأغاني الثعبية لتنمية بعض المفاهيم الاجتماعية لدى طفل الروضة، ماجستير، كلية التربية، جامعة المنيا. ه - هدى قناوي(ى . . ب): أدب الطفل وثقافته، المؤتمر الإقليمي الأول "الطفل العربي في ظل المتغيرات المعاصرة، مركز البحوث والدرسات والخدمات المتكاملة، كلية البنات، جامعة عين شمس.

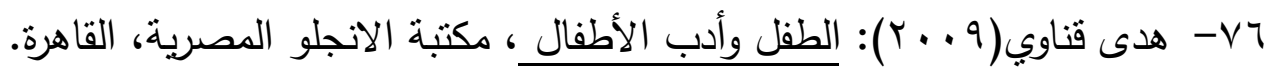

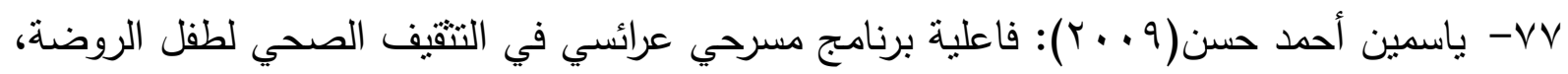
ماجستير، كلية رياض الأطفال، جامعة القاهرة.

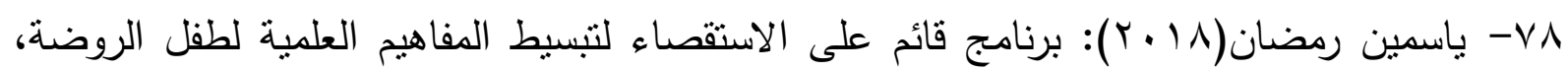
ماجستير، كلية التربية للطفولة المبكرة، جامعة القاهرة.

79- Boon, M. (2017): Measurements in the engineering sciences: an epistemology of producing knowledge of physical phenomena. In N. Mößner \& A. Nordmann (Eds.), New York: Routledge is an imprint of the taylor \& Francis Group.Pp203-219.

80- Bridikyte, M. (2000): Dialogical drama with puppets and children is creation of sense, Paper presented at the European Conference on quality in early childhood education 10th, London-England, Aug-Sep

81- ChuYeh,Y., LinLi,M.(2008):Age, Emotion regulation strategies , Temperament,Creative drama,And preschools creativity,Journal of Creative Behavior, 42(2), Pp. $131-149$.

82- Decoster,J., B.Kinzie,M., Whittaker,J., P.Willifordb,A. ,Mcguire,P., Lee,Y. \&R.Kilday,C. (2014): Myteachingpartner-math/science pre-kindergarten curricula and teacher supports: Associations with children's mathematics and science learning, Early Childhood Research Quarterly 29 , Pp.586-599.

83- Donald, R., (2010): Life science concept development among beginning kindergarten children form three different community settling, Emoryuni, Atlanta Georgia, Journal of Research in Science Teaching, 10(1),Pp. 39-50.

84- Donna, G. (2007): Pre-K music and the emergent reader: promoting literacy in a music enhanced environment, Early Childhood Education Journal, 35, Aug.

85- Driscoll, D.(2003): Guldelines for preschool learning experiences, Massachusetts department of education, Malden, Massachusetts. 
86- Enciso, P., Wolf, S., Coats, K. \& Jenkins, C. (2010): Children's literature:Standing in the shadow of adults, International Reading Association,June, 45(2), Pp.252-263.

87- Fusaro, M. \& Smith, M. (2018): preschoolers' inquisit- iveness and sciencerelevant problem solving,Early Child- Hood Research Quarterly ,42,Pp.119127.

88- Geerdts, M., Van, W., \& Gretchen, L. (2015): Daily animal exposure and children biological concepts, Journal of Experimental Child Psychology, 130, Pp.132-146.

89- Gelman, R., \& Brenneman, K.(2004):science learning path- ways for young children, Early Childhood Research Quarterly 19, Rutgers center for cognitive science, Rutgers University,Pp150-158.

90- Glazer, J.(2000): Literature for young children, Engl- wood cliffs, Merrill Pretice-Hall.

91- Harlen, W., (2000): The teaching of science in primary school, London, United kingdom: Rotledge Taylor and Francis Group.

92- Humphryes, J.(2000): Exploring nature with children , Young Children, 55(2), Pp.16-20.

93- Isbell, R., Sobol, J., Lindauer, L., \& Lowrance, A.(2004): The effects of storytelling and story reading on the oral language complexity and story comprehension of young children, Early Childhood Education Journal,,43, (3).

94- Justice, L. (2003): Emergent literacy intervention for vulnerable prescholars: Relative effects of town approaches, American Journal of SpeechLanguage Pathology, 12, (3), Aug.

95- Kartin,M.(2000): “Art in education where are you ?where should we be? who is involved? design for arts in education, Education Journal, 97(6).

96- Lake,J. (2000): literature \& science breakthroughs: connecting language and science skills in the elementary classroom. Ontario: Pembroke Publishers.

97- Lewin-Benham, A. (2006): One teacher ,20prescoolers and agoldfish environmental awareness emergent curriculum and documentation, National 
Association for the Education for the education of young children (Naec), 61(2), Pp28-34.

98- Mantzicopoulos, P. „Patrick, H., \& Samarapungavan, A. (2008): Young children's motivational beliefs about learning science, Early Childhood Research Quarterly 23, Pp378-394.

99- Mcguire, P., Lee,Y., \& R.Kilday, C.,(2014): Myteaching- partner math/science pre-kindergarten curricula and teacher supports: Associations with children's mathematics and science learning, Early Childhood Research Quarterly 29 ,Pp. 586-599.

100- Mills,C.(2004): Effects of working memory and present-ation condition on narrative production and inference skills in children with language learning impairment,Phd, The University of Tennessee, Knox- Ville.

101- Ping- Yun, S. (2003): Using drama and theatre to promote literacy development some basic classroom applica- tions, Eric Digest, Ed.

102- Prokop,P., Prokop,M. \& Tunnicliff,S.(2008): Effects of keeping animals as pets on children's concepts of vertebrates and invertebrates, International Journal of Science Education, 30(4), Pp431-449.

103- Robertson, W., (2009): Answers to science questions from the stop faking it! guy. virginia: National Science Teachers Association.

104- Robinson, L., (2005): The effect of automatic activity: free discovery to teach children in the kindergarten some scientific concepts, Journal of Research in Children Educational, 46( 3), Pp108- 119.

105- Sackes, M., Trundle, K., \& Flevares, L.(2009): Using children's literature to teach standerd-based science concepts in early years, Early childhood education journal, 36(5), Pp 415-422.

106- Samarapungavan, A., Montzicopoulos, P., Partich, H., \& French, B., (2009): The development and validation of science learning, Journal of Advanced Academic, 20( 3), Pp502-535.

107- Seefeldt,C.\&Gapler,A.(2006): Active experiences for active children science, $2^{\text {nd }} E d i$, New Jersy, Prantic Hall.

108- Tamicroft, B. T. (2009): Building arab americans culture identity and acceptance with children's literature, Reading teacher, 62( 3). 
109- Tarlowski, A.(2006): If its an animal it has axons, Exper- ience and culture in preschool children`s reasoning about animales cognitive development, Orlando, Elsevier, Sea harbor drive,21(3), Pp249-265.

110- Young Honga, S.,\& Diamondb, K. (2012): Two approaches to teaching young children science concepts, vocabulary, And scientific problemsolving skills, Early Childhood Research Quarterly, 27, Pp295- 305. 